\section{Pacific Northwest}

National Laboratory

Operated by Battelle for the

U.S. Department of Energy

\section{Prototype Database and User's Guide of Saturated Zone Hydraulic Properties for the Hanford Site}

P.D. Thorne

D.R. Newcomer

September 2002

Prepared for the U.S. Department of Energy

under Contract DE-AC05-76RL01830 


\section{DISCLAIMER}

This report was prepared as an account of work sponsored by an agency of the United States Government. Neither the United States Government nor any agency thereof, nor Battelle Memorial Institute, nor any of their employees, makes any warranty, express or implied, or assumes any legal liability or responsibility for the accuracy, completeness, or usefulness of any information, apparatus, product, or process disclosed, or represents that its use would not infringe privately owned rights. Reference herein to any specific commercial product, process, or service by trade name, trademark, manufacturer, or otherwise does not necessarily constitute or imply its endorsement, recommendation, or favoring by the United States Government or any agency thereof, or Battelle Memorial Institute. The views and opinions of authors expressed herein do not necessarily state or reflect those of the United States Government or any agency thereof.

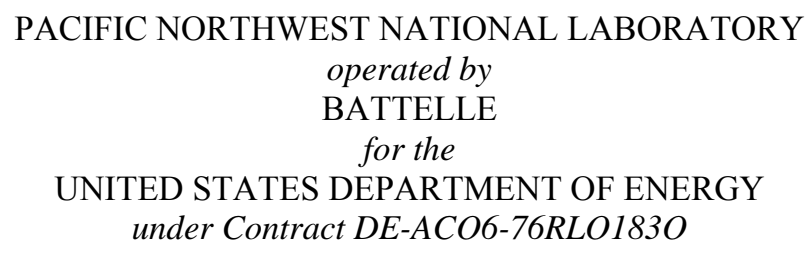

Printed in the United States of America

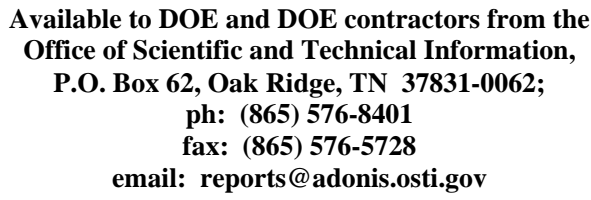

Available to the public from the National Technical Information Service, U.S. Department of Commerce, 5285 Port Royal Rd., Springfield, VA 22161 ph: (800) 553-6847 fax: (703) 605-6900

email: orders@ntis.fedworld.gov

online ordering: http://www.ntis.gov/ordering.htm 


\title{
Prototype Database and User's Guide of Saturated Zone Hydraulic Properties for the Hanford Site
}

\author{
P.D. Thorne \\ D.R. Newcomer
}

September 2002

Prepared for

the U.S. Department of Energy

under Contract DE-AC06-76RL01830

Pacific Northwest National Laboratory

Richland, WA 99352 



\begin{abstract}
Predicting the movement of contaminants in groundwater beneath the Hanford Site is important for both understanding the impacts of these contaminants and for planning effective cleanup activities. These predictions are based on knowledge of the distribution of hydraulic properties within the aquifers underlying the Hanford Site. The Characterization of Systems (CoS) Task, under the Groundwater Protection Project, is responsible for establishing a consistent set of data, parameters, and conceptual models to support estimates contaminant migration and impact (DeLamare 2000). Therefore, a prototype database of aquifer hydraulic properties has been developed for the Hanford Site. These hydraulic property data have been compiled from several different reports, as well as, from unpublished analyses. The data were originally calculated through analyses of measured hydraulic responses, such as water levels in a well that occur when a known stress is applied. The calculated hydraulic property values are based on fitting the measured hydraulic responses to a particular analytical model that incorporates both knowledge and assumptions about the tested aquifer system. Given that these assumptions and the analysis method affect the validity of the calculated hydraulic properties, several fields are provided in the prototype database for documenting test conditions and analysis procedures. A field is also provided for a "data quality" flag that will indicate whether the validity of the calculated hydraulic properties is considered reliable, questionable, or unknown.
\end{abstract}





\section{Table of Contents}
Abstract

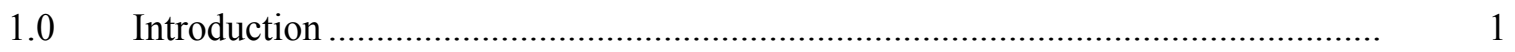

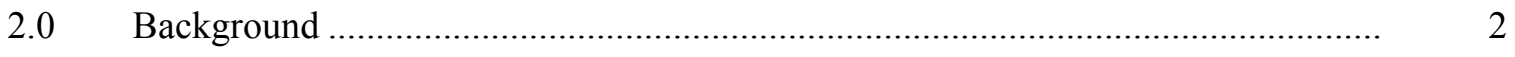
2.1 Hydraulic Properties .............................................................................. 2

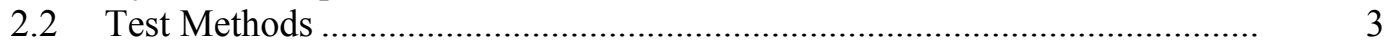
2.3 Quality of Available Data ....................................................................... 13

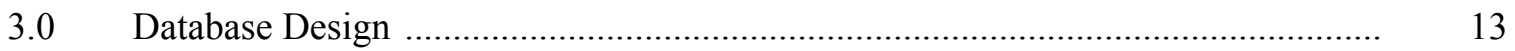

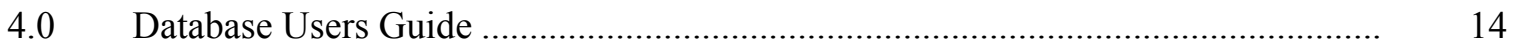

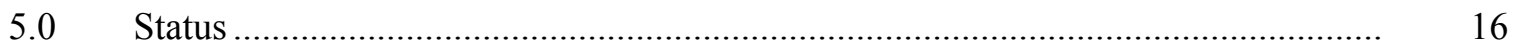

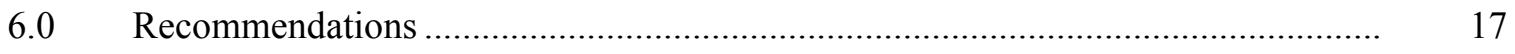

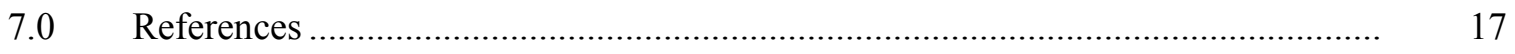

Appendix A: Prototype Saturated Zone Hydraulic Properties Database.............................. A.1

\section{List of Figures}

Figure 1. Characteristic Log-Log Drawdown and Drawdown Derivative Plots for Various Hydrogeologic Formation and Boundary Conditions.................................. 6

Figure 2. Predicted Slug-Test Response for Nonelastic Formation, Elastic Formation, and High Hydraulic Conductivity Sand-Pack Conditions 


\subsection{Introduction}

Groundwater movement through aquifers beneath the Hanford Site is a major pathway for transport of radioactive and hazardous chemical wastes that have been discharged in various locations on the Hanford Site since 1944. Contaminant plumes already exist within the upper aquifer system (Hartman et al. 2002). These are mainly from high-volume wastewater discharges that occurred during the period of nuclear materials production. Additional wastes are present in surface facilities, underground tanks, and within the vadose zone that lies between ground surface and the top of the uppermost aquifer. These wastes are a continuing source of contamination to the underlying aquifer. Removing these wastes and cleaning-up contamination in the vadose zone and the aquifer in order to limit impacts to human health and the environment is the focus of current work at the Hanford Site.

Predicting the movement of contaminants in groundwater and determining the discharge of contaminants to the Columbia River are important to both understanding the impacts of Hanford Site contaminants and to planning effective cleanup activities. These predictions are based on either analytical or numerical models of groundwater flow, both of which require knowledge of the three-dimensional distribution of hydraulic properties within the aquifers.

The Characterization of Systems (CoS) Task of the Groundwater Protection Project (formerly the Groundwater/Vadose Integration Project) is responsible for establishing a consistent set of data, parameters, and conceptual models needed to estimate the impacts of Hanford Site contaminants (DeLamare 2000). The CoS task is assembling data and information on several aspects of contaminant release, transport, and impact. These include the following elements:

- waste inventory

- contaminant release

- vadose zone

- groundwater

- Columbia River

- exposure and risk.

For each of the above elements, the CoS Task is assembling and integrating a multitude of databases and information to provide a technical basis for impact predictions and, ultimately, for informed planning of waste storage and cleanup activities.

The development of a central, uniform database where modelers and analysts can access available hydraulic property information will save much time and effort currently expended on finding and evaluating the data in diverse sources. It will also facilitate peer review and quality control of the data. Errors or questionable data can be more easily identified and possibly corrected. Establishing a central database should also provide more consistency in model parameters and results.

This report documents the development of a prototype database for saturated zone hydraulic properties. These property data generally result from the analysis of measured hydraulic responses, such as water levels in a well, that occur when a known stress is applied, such as pumping at a particular flow rate from a well a known distance from the measured well. The calculated hydraulic property values are based on fitting the measured responses to an analytical model that incorporates both knowledge and assumptions about the tested aquifer system. The same response data could, therefore, result in different hydraulic property values depending on 
the assumptions made about the analytical model (e.g., confined or unconfined aquifer). The database does not include the measured hydraulic responses (i.e., well drawdown measurements). However, it does attempt to identify the location of the measured responses and to document important assumptions about the analytical model used in calculating hydraulic properties.

Hydraulic property data for the aquifers underlying the Hanford Site have been compiled in several documents during the past 50 years. Two of the earliest were a classified 1953 report, later published as Newcomb et al. (1972), and Bierschenk (1957). Later compilations include Kipp and Mud (1973), who reported the results of several tests conducted in 1969, and Deju (1974). Newcomer (1992a and 1992b) compiled hydrologic test results for the 200 West and 200 East Areas, respectively. Thorne and Newcomer (1992) provided a review and partial compilation of sitewide test results and reanalyzed several tests using updated analysis methods. The database described in this report attempts to combine the information in these reports with results of recent hydrologic tests and to provide more complete information on test conditions and analysis assumptions. It also attempts to assign a data-quality flag to the test results to reflect the reliability of the hydraulic property estimates. The database is planned to be available electronically in a web-based format and to be updated regularly.

The purpose of this report is to document the prototype database of aquifer hydraulic properties, assemble data from multiple locations in a consistent format, and serve as a users guide for the database files that will be maintained in an electronic format and be accessible to interested parties. The prototype database presented in this document is incomplete and limited in scope. It is expected that population and refinement of the database will be a continuing process.

\subsection{Background}

Groundwater beneath the Hanford Site occurs in both a local, generally unconfined aquifer system and in regional aquifers confined by relatively low-permeability basalt flows. The local aquifer system is within unconsolidated to semiconsolidated sediments overlying the basalt bedrock. Parts of the local aquifer system are locally confined by mud units. However, because the entire suprabasalt aquifer system is interconnected on a site-wide scale, it has commonly been referred to as the Hanford "unconfined" aquifer while aquifers located within the Columbia River Basalts have been referred to as the basalt confined aquifer system.

\subsection{Hydraulic Properties}

The primary aquifer properties affecting groundwater flow are hydraulic conductivity $(\mathrm{K})$, specific storage (Ss), and aquifer thickness (b). Transmissivity (T) is the product of hydraulic conductivity and aquifer thickness. Storativity is the product of specific storage and aquifer thickness. For unconfined aquifers both the storativity associated with elastic aquifer response and the specific yield (Sy) from dewatering of the aquifer are important. In addition, effective porosity (ne) is an important parameter in determining groundwater velocity and rates of contaminant transport. Most sedimentary aquifers are anisotropic and the horizontal hydraulic conductivity $(\mathrm{Kh})$ is different than the vertical hydraulic conductivity $(\mathrm{Kv})$. The ratio of $\mathrm{Kv} / \mathrm{Kh}$ is called the vertical anisotropy. When combined with information on boundary conditions and hydraulic gradient, the distributions of these hydraulic properties provide a complete description of the groundwater flow system. Aquifer thickness is most commonly determined from the 
logging of geologic materials recovered during well drilling. Aquifer thickness may also be determined from downhole or surface geophysical measurements.

\subsection{Test Methods}

Aquifer hydraulic properties are usually determined by using wells to observe the water-level changes in response to an applied or natural stress on the aquifer. In the case of aquifer pumping tests and slug tests, the stress is applied by adding or removing water at a well. Natural stresses may result from changes in the water level of a surface-water body hydraulically connected to the aquifer, earth tides, or atmospheric pressure changes. Hydraulic properties may also be determined from laboratory tests on samples removed from boreholes or excavations. A disadvantage of these tests is that properties may be altered by disturbing the sample during removal, transport, and testing. The following discussion gives an overview of in-situ tests and conditions that may affect the quality of hydraulic property data determined from these tests.

Several different types of hydrologic tests have been conducted to determine hydraulic properties of aquifers beneath the Hanford Site. Pumping tests have been conducted at many wells using either a single-well configuration, where aquifer drawdown and recovery is measured in the pumped well, or a multiple-well configuration, where aquifer response is measured at one or more observation wells. Single-well pumping tests have been conducted more frequently because of the expense of installing multiple wells. Many single-well slug tests have also been conducted. These tests are generally performed more quickly and with less elaborate equipment than pumping tests. They also have an advantage in areas of groundwater contamination because it is not necessary to remove large volumes of contaminated groundwater. However, single-well slug tests are analyzable over a relatively narrow range of transmissivity and the results apply to only a small area surrounding the well. A multiple-well slug test method that avoids these problems to some extent has been used by Spane (1992).

In addition to these standard hydraulic test methods, a few estimates of hydraulic properties have been obtained from analysis of:

- tracer test results

- water-level responses to changes in Columbia River elevation

- formation of groundwater mounds under waste-water disposal areas.

Aquifer tests have been carried out under many different programs and projects at the Hanford Site. The results are contained in project files and various published and unpublished test reports. The quality of the analysis results varies over a wide range. Most test analyses are affected by formation and well conditions that do not exactly conform to the analysis method applied. These nonideal test conditions and their effect on analysis results are discussed in the following subsections. Test results may also be affected by external stresses such as barometric pressure changes or pumping at nearby wells. The severity of the resulting errors also varies widely. Therefore, the prototype database contains a field for a data quality flag to reflect the reliability of the hydraulic property estimate.

Brief descriptions of the test and analysis methods used for determining hydraulic properties of the unconfined aquifer at Hanford are provided below. Most of this information was taken from Thorne and Newcomer (1992) and Spane et al. (2001b). Additional details are available in these documents and in Spane (1993). 


\subsubsection{Constant-Rate Pumping Tests}

A constant-rate discharge (or pumping) test is performed by removing water from a well at a constant rate and measuring the associated drawdown and recovery of hydraulic head in the aquifer. Hydraulic head responses may be monitored at the pumping well, at one or more nearby observation wells, or both.

The mathematical equation describing drawdown, $\mathrm{s}$, in an aquifer resulting from transient radial flow of compressible groundwater to a well pumped at a constant rate was given by Theis (1935) as:

$$
s=\frac{Q}{4 \pi T} W(u)
$$

where: $\quad \mathrm{T}=$ transmissivity of the aquifer

$\mathrm{Q}=$ constant discharge rate

The dimensionless well function, $\mathrm{W}(\mathrm{u})$, is defined as:

$W(u)=\int_{u}^{\infty} \frac{e^{-u}}{u} d u$

where:

$$
u=\frac{r^{2} S}{1 T t}
$$

[dimensionless]

and where: $\quad \mathrm{r}=$ radial distance to the pumping well

$\mathrm{S}=$ storativity of the aquifer

[L]

[dimensionless]

The Theis equation makes several assumptions including: the aquifer is confined, homogeneous, isotropic, and of infinite lateral extent; the well is a line-sink (i.e., has no storage) and completely penetrates the aquifer; and flow is laminar. A number of other equations have been presented for cases where one or more of these assumptions is not met. The Boulton (1963) and Neuman (1974 and 1975) equations account for delayed yield from unconfined aquifers. The image well method (Ferris et al. 1962) may be used for analysis of tests in bounded aquifers. Corrections for the effects of vertical flow gradients caused by partially penetrating wells have been presented by Hantush (1962), Dagan (1967), Kipp (1973) and Neuman (1974).

Most of the constant-rate pumping tests conducted at Hanford have been analyzed using the Theis equation. These analyses applied either the type-curve matching method (Theis 1935) or semilog straight-line methods (Theis 1935, Cooper and Jacob 1946). Other Hanford tests (Kipp and Mud 1973) have utilized type-curve matching with the unconfined aquifer solution of Boulton (1963) and some have applied corrections for partial penetration of the pumping well and for aquifer dewatering at the pumped well. The WTAQ3 computer program (Moench 1997) has been used to generate aquifer pumping test type curves for analysis of some recent constant-rate pumping tests (Spane and Thorne 2000; Spane et al. 2001a; Spane et al. 2001b). This program generates type curves that represent a wide range of test and aquifer conditions, including partially penetrating wells, confined or unconfined aquifer models, well-skin effects, and wellbore storage at both the stress (pump) and observation (monitor) well locations. 


\section{Type-Curve Matching Method}

Type-curve matching methods are best suited to data from observation wells because friction loss at the pumping well may cause an additional component of drawdown independent of the aquifer response. This causes the data to be shifted vertically on the log-log plot employed in type-curve matching and introduces error in the calculated transmissivity and storativity values. Most tests at Hanford have had to rely on measurements of aquifer drawdown and recovery solely at the pumped well. Errors may have been introduced in some cases by applying type-curve matching methods for analysis of pumping well data. Attempts have been made to determine the friction loss component through step-drawdown tests and then correct the drawdown measurements prior to type-curve matching (Kipp and Mud 1973). However, when it can be applied, the semilog straight-line method is considered a more reliable technique for analyzing data from a pumping well.

\section{$\underline{\text { Semilog Straight-Line Method }}$}

The semilog, straight-line analysis techniques commonly used are based on either the Cooper and Jacob (1946) method (for drawdown analysis) or the Theis (1935) recovery method (for recovery analysis). As indicated by Cooper and Jacob (1946), semilog straight-line methods are only valid for data corresponding to small values of the parameter $u$. It is generally accepted that the method is valid when $\mathrm{u}<0.01$. However, in some cases the error introduced by using data corresponding to somewhat larger values of $u$ in straight-line analysis is minor (Chapuis 1992). These methods are theoretically restricted to the analysis of test responses from wells that fully penetrate nonleaky, homogeneous, isotropic, confined aquifers. Straight-line methods, however, may be applied under nonideal well and aquifer conditions if infinite-acting, radial flow conditions exist. Infinite-acting, radial flow conditions are indicated during testing when the change in pressure, at the point of observation, increases in proportion to the logarithm of time. Unfortunately, for many aquifer tests at the Hanford Site the combination of partially penetrating wells and unconfined aquifer conditions causes infinite-acting, radial flow conditions to not occur within a reasonable amount of pumping time. Review of previous test analyses has shown that many tests were incorrectly analyzed using the straight-line method when infinite-acting, radial flow conditions were not established. As discussed below, the use of diagnostic derivative methods (Bourdet et al. 1989) makes it easier to identify the range of test data where straight-line analysis is appropriate. The most likely source of error in this technique is to attempt to fit a straight-line to data collected before the straight-line approximation applies (large $u$ ), or to data that do not reflect radial flow conditions in an "infinite-acting" aquifer. Often, in Hanford Site tests, more than one straight-line segment will appear on a semilog plot due to nonideal aquifer conditions.

\section{Diagnostic Analysis and Derivative Plots}

It is important to recognize when nonideal well or aquifer effects are significant. When they are not significant, the aquifer displays "infinite acting" behavior. The appropriate analysis model can then be selected for calculating hydraulic properties from the response data. Nonideal conditions may be discerned by preparing a diagnostic plot of the test data and comparing it to characteristic curves associated with various nonideal conditions. Log-log plots of water level versus time have traditionally been used for diagnostic purposes and recently the derivative of the water level or pressure change has also been used (Bourdet et al. 1989) as a diagnostic tool. Use of derivatives has been shown to significantly improve the diagnostic and quantitative analysis of various hydrologic test methods (Bourdet et al. 1989; Spane 1993). The improvement in test 
analysis is attributed to the sensitivity of pressure derivatives to various test/formation conditions. Specific applications for which derivatives are particularly useful include

- determining formation-response characteristics (confined or unconfined aquifer) and boundary conditions (impermeable or constant head) that are evident within the test data

- assisting in the selection of the appropriate type-curve solution through combined typecurve/ derivative plot matching

- determining when infinite-acting, radial flow conditions are established and, therefore, when straight-line analysis methods are applicable.

Figure 1 shows log-log drawdown and derivative responses that are characteristic of some commonly encountered formation conditions. The early data, occurring before the straight-line approximation is valid or where wellbore storage is dominant, produce a steep, upward-trending derivative. The derivative normally decreases during transition from wellbore storage to radial flow and stabilizes at a constant value when infinite-acting, radial flow conditions are established.

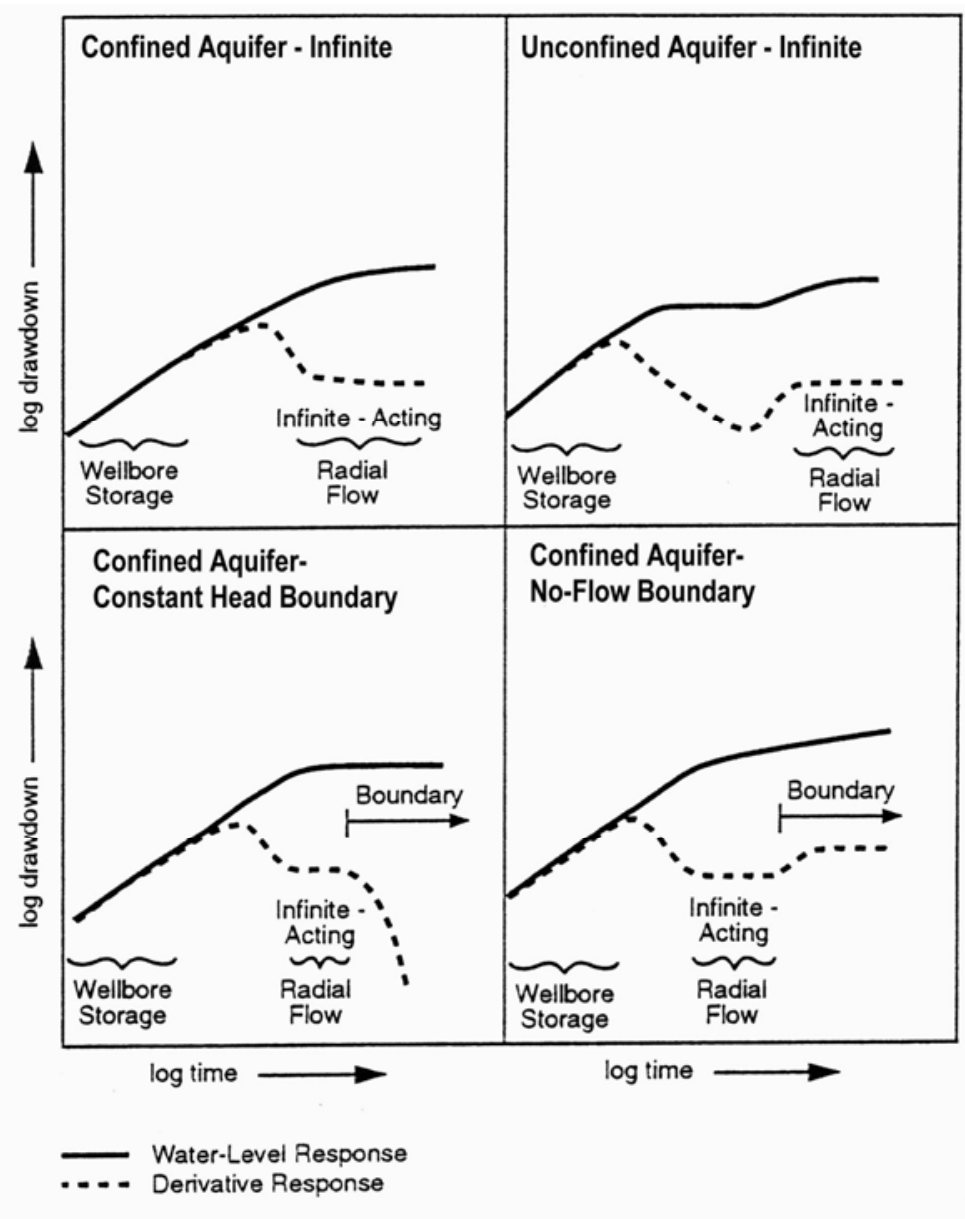

Figure 1. Characteristic Log-Log Drawdown and Drawdown Derivative for Various Hydrogeologic Formation and Boundary Conditions Plots

(adapted from Spane 1993) 
The stable derivative reflects the straight-line on the semilog plot for infinite-acting radial flow. Unconfined aquifers and formations exhibiting double-porosity characteristics (e.g., fractured media) may show two stable derivative sections at the same vertical position separated by a "valley" that represents the transition from one storage value to the other. Diagnostic derivative plots are also useful in identifying boundary effects.

A linear, no-flow boundary will result in a doubling of the magnitude of the derivative. If radial flow is established before the influence of the boundary is seen, a stable derivative will occur for a time followed by an upward shift to twice the original value. Constant-head boundaries display a downward trend in the derivative, which may be preceded by a stable derivative if radial flow conditions occur before the boundary effect becomes dominant.

The diagnostic log-log plots mentioned above are useful in identifying the radial flow, part of the test data, and regions of data affected by nonideal conditions. The derivative plotting technique is particularly helpful in determining data where semilog analysis is valid (Bourdet et al. 1989). A $\log -\log$ plot of the head response versus time is prepared and the derivative of the semilog plot is then calculated and graphed on the log-log plot along with the water-level data. For recovery data, the "Agarwal equivalent time function" (Agarwal 1980), or some other superposition function, is used in calculating the derivative. This accounts for the effect of the pumping period and causes the recovery data to fall on a straight-line (constant derivative) on the semilog plot. The effects of various aspects of the well-aquifer system show up on the derivative plot and can be easily correlated with features of the log-log plot that have traditionally been used to diagnose test behavior. As shown in Figure 1, the early data, occurring before the straight-line approximation is valid or where wellbore storage is dominant, produces a steep upward trending derivative. The derivative normally decreases during transition from wellbore storage to radial flow, and stabilizes at a constant value when radial infinite-acting flow conditions are established. The stable derivative reflects the straight-line on the semi-log plot for infinite-acting radial flow. Delayed yield and double-porosity aquifers may show two stable derivative sections at the same vertical position separated by a "valley," this represents the transition from one storage value to the other.

Pressure derivative plots are also useful in identifying boundaries. A linear no-flow boundary will result in a doubling of the magnitude of the derivative. If radial flow is established before the influence of the boundary is seen, a stable derivative will occur for a time followed by an upward shift to twice the original value. Constant-head boundaries show up as a downward trend in the derivative, which may be preceded by a stable derivative if radial flow conditions occur before the boundary effect becomes dominant.

\subsubsection{Slug Tests}

Slug tests are conducted by instantaneously raising or lowering the water level in a well and monitoring the recovery to static formation conditions. These tests are generally easier to conduct and require less time than aquifer pumping tests. However, slug tests stress a relatively small volume of the aquifer around the well and, therefore, have a limited zone of influence. Slug tests are popular for determining the hydraulic properties of aquifers at hazardous waste sites. This is partly because they do not require the withdrawal of large volumes of water. Disposing of contaminated groundwater from pumping tests may pose a significant problem at such sites. Slug test results are also commonly used to estimate hydraulic properties for use in the design of subsequent hydrologic tests having greater areas of investigation (e.g., slug interference and constant-rate pumping tests). Slug tests have been conducted at many of the wells installed on the Hanford Site. 
The range of transmissivities for which single-well slug tests give analyzable results is also limited. If the transmissivity is too low, a very long time may be required for a sufficient percentage of recovery to occur. In these situations, steps can be taken to reduce wellbore storage and speed the response for low-transmissivity tests. If the transmissivity is too high, friction loss at the well is dominant and the test results are not analyzable. Single-well slug tests are generally applicable for transmissivities below $100 \mathrm{~m}^{2} / \mathrm{d}$ (Spane 1992) and multiple-well slug interference tests may provide good results for transmissivities up to $1000 \mathrm{~m}^{2} /$ day (Spane 1992).

Several different methods have been presented for analyzing the water-level response to a singlewell slug test. The method presented by Bouwer and Rice (1976) and updated by Bouwer (1989) is designed for unconfined aquifer testing and includes provisions for partially penetrating wells. This analysis technique is commonly used on the Hanford Site because most wells partially penetrate the unconfined aquifer. The analysis method presented by Cooper et al. (1967) is based on non-steady radial flow of a compressible fluid in a confined aquifer. These analysis methods have been most commonly employed at the Hanford Site and are discussed in more detail below.

\section{Bouwer and Rice Analysis Method}

The Bouwer and Rice (1976) analysis method and the similar Hvorslev (1951) method are based on equations describing steady-state radial flow of an incompressible fluid. Hydraulic conductivity $(\mathrm{K})$ is given by:

$$
K=\frac{r_{c}^{2} \ln \left(R_{e} / r_{w}\right)}{2 L_{e}} \frac{1}{t} \ln \frac{y_{o}}{y_{t}}
$$

where: $r_{c}=$ radius of the casing

$$
\begin{array}{lll}
\mathrm{r}_{\mathrm{w}}= & \text { radius of the well } & {[\mathrm{L}]} \\
\mathrm{L}_{\mathrm{e}}= & \text { length of the open well section } & {[\mathrm{L}]} \\
\mathrm{R}_{\mathrm{e}}= & \text { effective radius of influence } & {[\mathrm{L}]} \\
\mathrm{t}= & \text { time since the test began } & {[\mathrm{T}]} \\
\mathrm{y}_{\mathrm{t}}= & \text { water level }- \text { static water level } \\
\mathrm{y}_{\mathrm{o}}= & \text { induced water-level change at beginning of test }[\mathrm{L}]
\end{array}
$$

For the Hvorslev method, Re is assumed to be equal to the length of the open interval. Bouwer and Rice (1976) provide empirical formulas for determining $\ln \left(\mathrm{R}_{\mathrm{e}} / \mathrm{r}_{\mathrm{w}}\right)$, based on the results of electrical analog studies of different flow system geometries.

For both these analysis methods, water-level data are plotted on a logarithmic scale versus time on an arithmetic scale. Based on the above equation, the result should be a straight-line, at least over a section of the plot corresponding to early time. The quantity $[\ln (\mathrm{yo} / \mathrm{yt})] / \mathrm{t}$ can be determined graphically from the straight-line portion and used to calculate $\mathrm{K}$. In practice, near 
borehole effects, such as a gravel pack or other altered permeability zone near the well, sometimes cause a deviation from the predicted single straight-line (Bouwer 1989).

The Bouwer and Rice method is a well-known technique and is widely applied in the analysis of slug tests. A number of analytical weaknesses, however, limit the successful application of the Bouwer and Rice method for analyzing slug-test response. These weaknesses constrain its application to slug-test responses that exhibit steady-state flow, isotropic conditions, no well-skin effects, and no elastic (storage) formation response. Unfortunately, these limitations are commonly ignored and the Bouwer and Rice method has been applied to slug-test responses that do not meet the test analysis criteria. A more detailed discussion on the analytical limitations of the Bouwer and Rice method is provided in Hyder and Butler (1995), Brown et al. (1995), and Bouwer (1996).

For slug tests exhibiting elastic storage response, it should be noted that improved estimates can be obtained if analysis criteria specified in Butler $(1996,1998)$ are observed. Figure 2 shows the predicted, normalized, slug-test response for three well/aquifer-test conditions: 1) nonelastic formation, 2) elastic formation, and 3) elastic formation with high-K sandpack effects. The test responses were calculated using the KGS model described in Liu and Butler (1995) for the given test conditions listed in Figure 2. As shown, the presence of elastic aquifer storage (i.e., specific storage, $\mathrm{S}_{\mathrm{s}}$ ) and effects of a high-permeability sand pack cause curvilinear test responses (concave upward) that deviate from the predicted linear, nonelastic formation response. When this diagnostic curvilinear response is exhibited in the slug-test response, Butler $(1996,1998)$

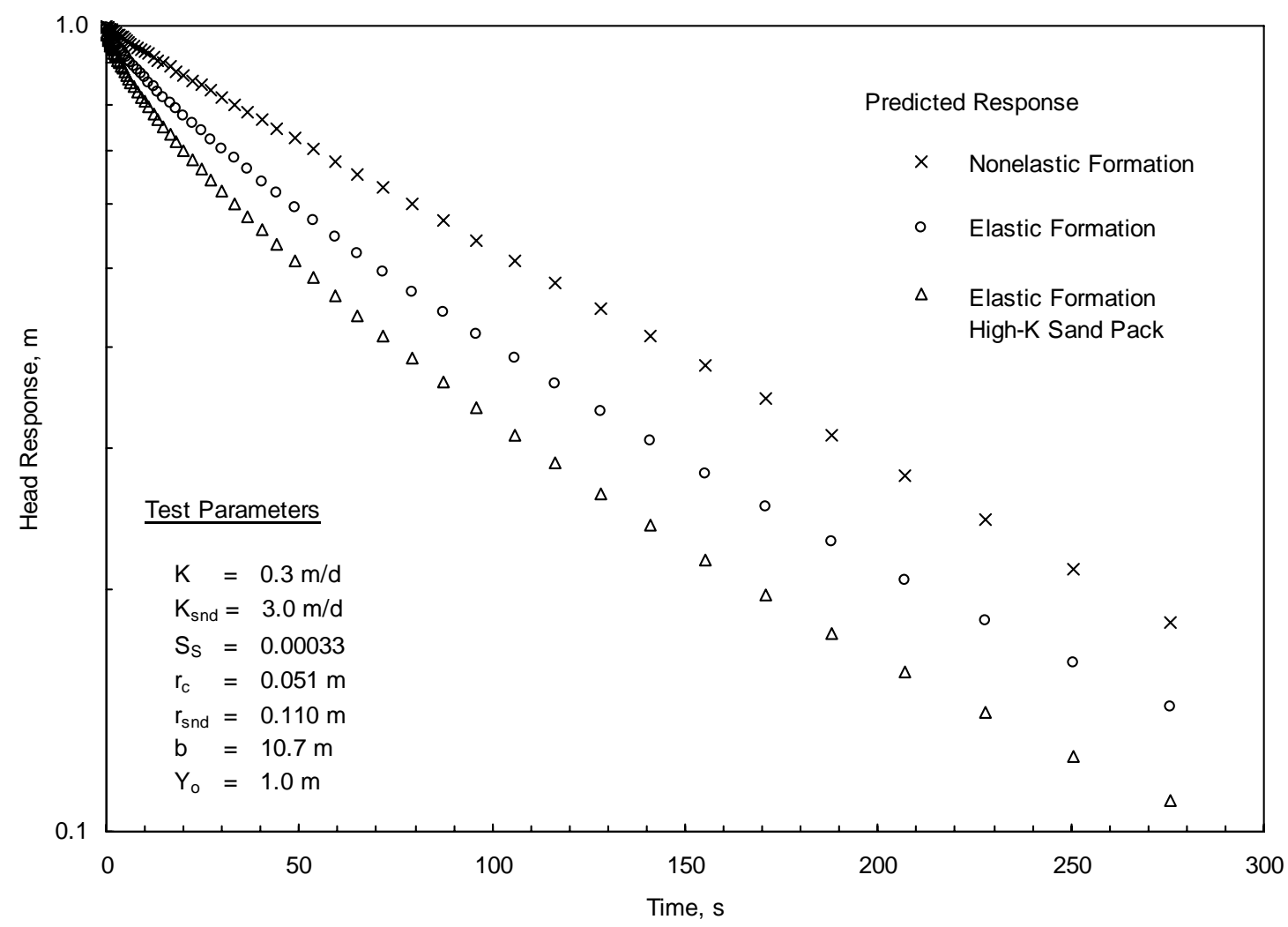

Figure 2. Predicted Slug-Test Response for Nonelastic Formation, Elastic Formation, and High Hydraulic Conductivity Sand-Pack Conditions (adapted from Spane et al. 2000b) 
recommends that the late-time test analysis be employed (i.e., the normalized head segment between 0.3 and 0.2) when using the Bouwer and Rice (1976) method. As shown in Figure 3.1, the two elastic curvilinear test responses over the specified late-time segment closely parallel the nonelastic test-formation response. This indicates that quantitative estimates for $\mathrm{K}$ can be obtained using the Bouwer and Rice method over a wide range of test-response conditions (nonelastic or elastic formation, high-K sandpack effects), if the proper analysis criteria are applied.

Due to its semiempirical nature, analytical results obtained using the Bouwer and Rice method (i.e., in contrast to results obtained using the type curve analysis method) may be subject to error. Bouwer and Rice (1976) indicated that the K estimate, using their analysis method, should be accurate to within 10\% to $25 \%$. Hyder and Butler (1995) state an accuracy level for the Bouwer and Rice method within $30 \%$ of actual for homogeneous, isotropic formations, with decreasing levels of accuracy for more complex well/aquifer conditions (e.g., well-skin effects). For these reasons, greater credence is generally afforded the analytical results obtained using the typecurve-matching approach, which has a more rigorous analytical basis.

\section{Type Curve Analysis Method}

A slug test analysis method based on non-steady radial flow of a compressible fluid in a confined aquifer was presented by Cooper et al. (1967). They present type curves of dimensionless head response, $H_{D}$, versus a dimensionless time parameter, $\beta$, for various values of a dimensionless wellbore storage parameter, $\alpha$. These parameters are defined by:

$$
\begin{array}{llc}
\mathrm{H}_{\mathrm{D}} & =\mathrm{H} / \mathrm{H}_{\mathrm{o}} & {[\text { dimensionless] }} \\
\beta & =\mathrm{Tt} / \mathrm{r}_{\mathrm{c}}{ }^{2} & {[\text { dimensionless] }} \\
\alpha & =\mathrm{r}_{\mathrm{w}}{ }^{2} \mathrm{~S} / \mathrm{r}_{\mathrm{c}}{ }^{2} & \text { [dimensionless] }
\end{array}
$$

where, $\mathrm{H}=$ observed head - pretest static head [L]

$$
\begin{array}{ll}
\mathrm{H}_{\mathrm{o}} & =\text { instantaneous head change at start of test } \\
\mathrm{t} & =\text { time since start of test } \\
\mathrm{r}_{\mathrm{c}} \quad \begin{array}{l}
\text { = radius of well casing where } \\
\quad \text { water level chnge occurs }
\end{array} \\
\mathrm{r}_{\mathrm{w}} \quad=\text { effective radius of well }
\end{array}
$$

Test data are plotted in the form $\mathrm{H} / \mathrm{Ho}$ versus $\log \mathrm{t}$ and matched to the dimensionless type curves to determine values for $\alpha$ and $\beta$. Transmissivity and storativity can then be calculated by rearranging the above equations for $\alpha$ and $\beta$. However, in practice, the method does not give reliable estimates of storativity because the shape of the curves differ only slightly for changes in $\alpha$ of an order of magnitude (Cooper et al. 1967).

Although the type-curve method is based on the response of a fully penetrating well in a confined aquifer, acceptable results may be obtained for unconfined aquifers and partially penetrating 
wells as long as the vertical flow component is small and the saturated thickness of the aquifer does not change significantly during the test (Walter and Thompson 1982). All or any part of the slug-test response can be used in the analysis procedure. Therefore, analysis of unconfined aquifer tests can be limited to the appropriate portion of the response.

\section{$\underline{\text { Heterogeneous Formation Effects on Slug Tests }}$}

Inherent in the analytical methods discussed above is the assumption that the test interval is homogeneous. A number of formation heterogeneities, however, can exert significant influence on slug test responses. These include: multi-layers of varying hydraulic properties within the well-screen section, presence of linear boundaries, and radial variation of hydraulic properties with distance from the well (i.e., radial boundaries).

The effects of multi-layer conditions within the test interval have been examined previously by Butler et al. (1994) and Butler (1998). These studies indicate that the presence of multi-layers of varying hydraulic properties cannot be distinguished from the pattern of the slug test response. For well screens that fully penetrate a heterogeneous, multi-layer aquifer, the hydraulic conductivity estimated from the slug test will be an arithmetic average of the thickness-weighted $\mathrm{K}_{\mathrm{h}}$ values of the individual layers. For well screens that partially penetrate the upper-part of a multi-layer aquifer, the hydraulic conductivity estimated from the test will also represent a thickness-weighted arithmetic average, as long as significant vertical leakage does not occur from layers underlying the test interval.

The effects of linear boundaries on slug test response have been examined previously by Karasaki et al. (1988), and Guyonnet et al. (1993). These effects are largely dependent on the nature of the boundary (i.e., no-flow or constant-head), proximity to the test well, and the storage characteristics of the aquifer and well. As a generalization, Guyonnet et al. (1993) state that noflow boundaries cause the slug test response to deviate from and delay recovery, while constanthead boundaries cause the slug test to recover faster than that predicted for a corresponding unbounded system response. Karasaki et al. (1988) accounts for the presence of linear boundaries within slug test response by employing image-well theory. The effect of linear boundaries is very similar to that imposed by radial boundaries - this is discussed below.

The effects of radial variations of hydraulic properties surrounding the test well have been investigated previously in studies examining slug tests in the presence of finite-thickness skin (e.g., Moench and Hsieh 1985). A finite-thickness skin is essentially a radial boundary condition surrounding a fully-penetrating well where the inner zone has significantly different hydraulic properties than the outside zone. A negative skin refers to the case where $\mathrm{K}_{\mathrm{h}}$ of the inner zone is much greater than that of the outer zone (i.e., $\mathrm{K}_{1}>>\mathrm{K}_{2}$ ); while a positive skin denotes the opposite condition (i.e., $\mathrm{K}_{1}<<\mathrm{K}_{2}$ ). The effects of a radial boundary on slug test response are largely a function of the contrast in $\mathrm{K}_{\mathrm{h}}$ for the inner and outer zone, the storage characteristics, and radial distance from the well to the boundary.

\subsubsection{Multiple-Well Slug Interference Tests}

Multiple-well slug interference tests use observation wells to monitor the aquifer response to a slug test (Spane 1992; Spane 1996). This method gives analyzable results for aquifers that are too transmissive for a single-well slug test and can also provide reliable estimates of specific yield. The analysis method is based on the analytical solutions and boundary conditions presented in Cooper et al. (1967). Although the analysis is strictly valid only for a fully 
penetrating well in an unconfined aquifer, it also gives valid results for partially penetrating wells and unconfined aquifer conditions if radial flow conditions exist during the analyzed portion of the test and the aquifer saturated thickness does not change significantly during the test (Spane 1992). Portions of the test response where radial flow conditions are established can be detected through diagnostic analysis using pressure-derivative techniques discussed above. A field evaluation of this technique (Spane and Thorne 1995) showed that results were comparable to the results of a constant-rate discharge test at a site with favorable test conditions (i.e., moderate transmissivity and appropriate well spacing).

\subsubsection{Other Hydrologic Test Methods}

Other methods that have been applied to determine hydraulic properties for the unconfined aquifer at Hanford include:

- analysis of aquifer water-level changes in response to river-stage fluctuations

- analysis of water-table mound formation resulting from waste-water discharges

- multiple-well tracer tests and single-well dilution tests

- inverse numerical models.

At this time, results of these tests have not been included in the prototype database. However, they are regarded as valuable information and should be included in the future. Some of these methods have the advantage of representing a larger volume of the aquifer and incorporating aquifer heterogeneity over this larger area into the results. The analysis of responses to river stage fluctuations can only give a value for aquifer dispersivity $(\mathrm{T} / \mathrm{S})$; calculating transmissivity requires assuming a storativity value. Tracer tests must be analyzed in conjunction with other hydrologic test results.

\subsubsection{Barometric Pressure Effects}

The analysis of well water-level responses during hydrologic tests provides the basis for estimating hydraulic properties. Barometric pressure fluctuations, however, can have a discernible impact on well water-level measurements. This barometric response is most severe in confined aquifer wells where it is immediate. However, wells completed within unconfined aquifers may exhibit a time-lagged response to barometric changes (Weeks 1979; Rasmussen and Crawford 1997). The time-lagged response in unconfined aquifers is caused by the time required for the barometric pressure change to be transmitted to the water table through the vadose zone compared to the instantaneous transmission of barometric pressure through the open well.

Barometric responses have the greatest impact on tests with relatively small head changes, such as responses in observation wells during pumping tests or slug-interference tests. In some tests, the barometric response may be of similar or greater magnitude than the test response.

Barometric effects are generally not significant for single-well pumping and slug tests unless the test response is very small.

To determine the significance of barometric effects, water-level changes should be monitored during a baseline period before or after a test and compared to the corresponding barometric pressure changes. The barometric responses can then be analyzed and removed from the 
recorded water levels using the multiple-regression deconvolution techniques described in Rasmussen and Crawford (1997) and Spane (2001a; 2001b). This technique relies on a leastsquares fit of the water-level change to the corresponding barometric pressure change and timelagged earlier barometric pressure changes.

\subsection{Quality of Available Data}

Hundreds of aquifer pumping tests and slug tests have been conducted on wells at Hanford to determine hydraulic properties. However, the accuracy of the hydraulic property results is questionable for many of these tests. This is mainly because of the complexity of the flow system and the simplifying assumptions inherent in the analysis methods. Many tests have also been affected by inadequate and irregular pumping rates, short durations, noisy data, barometric effects, borehole storage effects, and less than ideal well construction. Observation well data are generally required to determine storativity and specific yield, and relatively few multiple-well tests have been performed. Because of these problems, each analysis in the database requires a review and assignment of a data quality flag. This flag will indicate that the reliability of the calculated hydraulic properties is either: 1) reliable, 2) questionable, or 3) unknown.

Because the depth to the water table beneath parts of the Hanford Site has changed dramatically over the period of Hanford operations, different sediments may be saturated at different times. This will cause the $\mathrm{T}$ and average $\mathrm{K}$ at a well to change depending on the position of the water table. This is particularly important in areas where the water table has moved upward from the Ringold Formation into the more permeable Hanford formation. Therefore, it is important to note the depth to the static water table at the time of the test. This information has been included as a field in the database.

\subsection{Database Design}

The primary purpose of creating a database for saturated zone hydraulic properties is to provide input and comparison (calibration) data for numerical model simulations of groundwater flow and contaminant transport. Hydraulic properties - together with boundary conditions, initial conditions, and other parameter data sets - form a conceptual model of the aquifer system. Therefore, selection of hydraulic properties included in the database was based on input requirements of the numerical and analytical models. These parameters include the following:

- Transmissivity (T)

- Storativity (S)

- Aquifer thickness (b)

- Hydraulic conductivity (K)

- Storage coefficient (Ss)

- Specific yield (Sy)

- Vertical anisotropy $(\mathrm{Kv} / \mathrm{Kh})$

- Effective porosity (ne).

Depending on the test and analysis method, either $\mathrm{T}$ or $\mathrm{K}$ is directly determined from the analysis and the dependent parameter ( $\mathrm{K}$ or $\mathrm{T}$ ) is then calculated based on the aquifer thickness (b). The storage coefficient (Ss) is not normally calculated directly from aquifer test analyses, therefore, it 
was not included as a database field. It can be calculated from $\mathrm{S}$ based on the aquifer thickness. In some cases, a parameter that cannot be determined from the analysis may be assumed (based on expert knowledge of independent information) to support the calculation of other parameters. Therefore, the database contains fields associated with each parameter to indicate whether the value was determined from the analysis, calculated based on the aquifer thickness, or assumed based on independent information.

The prototype database was created using an EXCEL spreadsheet as the primary template. Each test has at least 36 fields (listed below). Additional fields apply for particular test types and for observation wells. Each of the fields can be designated as one of the following types of information.

- Raw Observational Data - Measurements or observations made during or associated with the execution of a given test procedure (e.g., measured aquifer thickness or depth to water).

- Raw Analytical Data - Data from a given procedure (e.g., partial penetration percentage calculated from aquifer thickness and measure well configuration).

- Interpreted Data - Information generated from a subjective analysis of raw analytical/field data and/or interpretations made to classify or categorize the raw analytical data (e.g., transmissivity calculated from fitting a type-curve based on a particular analytical model).

- Qualitative Data - Data that are not in numerical form (e.g., test type).

The database records are indexed by well name and test date (start date for tests lasting longer than one day). For some cases, more than one test may have been completed in a day. Therefore, another "test sequence" field was added to differentiate these test records. This field contains a, $\mathrm{b}$, c, etc. for cases where more than one test was started on the same day. Additional fields in the database provide information on the type of test, type of analysis, and supporting information on the tested interval and test conditions. These fields are described in the following sub-section. Certain fields are only applicable for particular types of tests. For example, observation well information is only applicable to multiple well tests. Therefore, it is recommended that an interactive database would only show those fields for the appropriate type of test. All fields currently included in the prototype database are listed below and units are specified where applicable.

\subsection{Database Users Guide}

This section lists each of the fields included in the prototype database of saturated hydraulic properties. For fields that have a limited set of possible string entries, the possible entries are listed in parenthesis. Units of dimensional parameters are shown in square brackets. For the "source" fields that follow the $\mathrm{T}, \mathrm{Kh}, \mathrm{Kv} / \mathrm{Kh}, \mathrm{S}, \mathrm{Sy}$, and Ss fields, an entry of "analysis" indicates that the value was determined directly from an analysis of hydraulic response data. An entry of "calculated" indicates that the value was calculated from a related parameter such as $\mathrm{K}=\mathrm{T} / \mathrm{b}$ and an entry of "assumed" means that the value was assumed based on expert opinion or independent information to facilitate the analysis. Fields for which the entry determines whether additional fields are applicable are marked with an *. 
Index fields displayed for all tests are:

- well name

- test start date

- sequence ("a", "b", "c", etc. for more than one test at this well on this date).

Results fields displayed for all tests are:

- $\operatorname{transmissivity~}(\mathrm{T})\left[\mathrm{m}^{2} / \mathrm{d}\right]$

- $\quad$ source of T value (analysis, calculated, or assumed)

- aquifer thickness (b) [m]

- horizontal hydraulic conductivity $(\mathrm{Kh})[\mathrm{m} / \mathrm{d}]$

- $\quad$ source of Kh value (analysis, calculated, or assumed)

- vertical anisotropy $\mathrm{Kv} / \mathrm{Kh}$ [dimensionless]

- $\quad$ source of $\mathrm{Kv} / \mathrm{Kh}$ (analysis, calculated, or assumed)

- $\quad$ specific yield (Sy) [dimensionless]

- $\quad$ source of Sy (analysis, calculated, or assumed)

- $\quad$ storativity (S) [dimensionless]

- $\quad$ source of S (analysis, calculated, or assumed)

- effective porosity (ne [dimensionless]

- $\quad$ source of ne(analysis, calculated, or assumed).

Information fields displayed for all tests are:

- test type (constant rate/step/slug) *

- aquifer type (unconfined/confined)

- single or multiple well (single or multiple) *

- quality flag

- reference / source

- data location

- analysis method

- barometric effects removed (yes or no)

- analysis date

- static depth to water at time of test, below ref point [m]

- reference point elevation [m]

- reference datum (ground surface, top of casing, brass cap, etc.)

- stress well open interval, top depth below ref point [m]

- stress well open interval, bottom depth below ref point [m]

- percentage of aquifer penetration, stress well [percentage] (or unknown)

- saturated open interval length [m]

- hydrogeologic unit tested

- maximum head change at stress well [m]

- comments.

Fields displayed for "constant rate test" are:

- pumping duration [min]

- flow rate $[\mathrm{L} / \mathrm{min}]$.

Fields displayed for "step test" are: 
- total pumping duration [min]

- $\min$ flow rate $[\mathrm{L} / \mathrm{min}]$

- max flow rate [L/min]

- calculated head loss - friction [m]

- calculated well efficiency [percentage].

Fields displayed for "slug test" are:

- $\quad$ slugging method (withdrawal, injection).

Fields displayed for "multiple" well tests are:

number of observation wells.

Fields displayed for each observation well (determined by number of observation wells) are:

- observation well name

- distance from stress well [m]

- reference point elevation [m]

- reference datum (ground surface, top of casing, brass cap, etc.)

- observation well open interval, top depth below ref point [m]

- observation well open interval, bottom depth below ref point [m]

- percentage of aquifer penetration, observation well [percentage] (or unknown)

- saturated open interval length [m]

- maximum observed head change [m]

- $\operatorname{transmissivity~}(\mathrm{T})\left[\mathrm{m}^{2} / \mathrm{d}\right]$

- $\quad$ source of T value (analysis, calculated, or assumed)

- aquifer thickness (b) [m]

- horizontal hydraulic conductivity $(\mathrm{Kh})[\mathrm{m} / \mathrm{d}]$

- $\quad$ source of Kh value (analysis, calculated, or assumed)

- vertical anisotropy $\mathrm{Kv} / \mathrm{Kh}$ [dimensionless]

- $\quad$ source of $\mathrm{Kv} / \mathrm{Kh}$ (analysis, calculated, or assumed)

- $\quad$ specific yield (Sy) [dimensionless]

- $\quad$ source of Sy (analysis, calculated, or assumed)

- $\quad$ storativity (S) [dimensionless]

- $\quad$ source of S (analysis, calculated, or assumed)

- effective porosity (ne) [dimensionless]

- $\quad$ source of ne (analysis, calculated, or assumed).

\subsection{Status}

This effort has focused on establishing a database format and providing a prototype set of data that are currently available. Many of the entries in the prototype database are incomplete and additional information must be obtained from the original hydraulic test records. The "data quality" field has not been completed for any test records and must be assigned based on expert review of the test records. There are also additional hydraulic tests that have not yet been included in the prototype database. 


\subsection{Recommendations}

Establishing the prototype database of aquifer hydraulic properties is a first step towards the goal of developing a standardized, consistent, reliable, and centralized database. However, this effort requires additional work to become a complete, integrated, and functional database. The following are recommendations for completing this effort:

- incorporate the prototype database into the $\operatorname{CoS}$ database management system and establish configuration control

- assign responsibility for updating the database and determining the data quality flag for each test to the groundwater technical element representative of $\mathrm{CoS}$

- create an interface that allows the user to interactively access the aquifer hydraulic property data

- provide links to data from other complimentary databases (e.g., geologic, geochemistry) and link the aquifer hydraulic property data to other databases, including GIS databases

- capture newly acquired aquifer hydraulic property data and update the database following a review of the acquired data

\subsection{References}

Agarwal, R. G. 1980. "A New Method to Account for Producing Time Effect When Drawdown Type Curves are Used to Analyze Pressure Buildup and Other Test Data." SPE Paper 9289, Soc. of Petroleum Engineers, Richardson, Texas.

Bierschenk (1957).

Boulton, N. S. 1963. "Analysis of Data from Nonequilibrium Pumping Tets Allowing for Delayed Yield from Storage." Proc. Inst. Civil Eng. 26:469-482.

Bourdet, D., J. A. Ayoub, and Y. M. Pirad. 1989. "Use of Pressure Derivative in Well-Test Interpretation." SPE Formation Evaluation, June 1989:293-302.

Bouwer, H. 1989. "The Bouwer and Rice Slug Test - An Update." Ground Water 27(3):304309.

Bouwer, H. 1996. "Discussion of Bouwer and Rice Slug Test Review Articles." Ground Water 34(1):171.

Bouwer, H. and R.C. Rice. 1976. "A Slug Test for Determining Hydraulic Conductivity of Unconfined Aquifers with Completely or Partially Penetrating Wells." Water Resources Research 12(3):423-428. 
Brown DL, TN Narasimhan, and Z Demir. 1995. "An Evaluation of the Bouwer and Rice Method of Slug Test Analysis.” Water Resources Research 31(5):1239-1246.

Butler JJ, Jr. 1996. "Slug Tests in Site Characterization: Some Practical Considerations." Environmental Geosciences 3(3):154-163

Butler JJ, Jr. 1998. The Design, Performance, and Analysis of Slug Tests. Lewis Publishers, CRC Press, Boca Raton, Florida.

Butler, JJ, Jr., GC Bohling, ZH Hyder, and CD McElwee. 1994. "The Use of Slug Tests to Describe Vertical Variations in Hydraulic Conductivity.” Journal of Hydrology 156:137-162.

Chapuis, R.P. 1992. "Using Cooper-Jacob Approximation to Take Account of Pumping Well Pipe Storage Effects in Early Drawdown Data of a Confined Aquifer." Ground Water 30(3):331337.

Cooper, H.H., Jr. and C.E. Jacob. 1946. "A Generalized Graphical Method for Evaluating Formation Constants and Summarizing Well Field History." Trans. Amer. Geophys. Union 27:526-534.

Cooper, H.H., Jr., J. D. Bredehoeft, and I. S. Papadopulos. 1967. "Response of a Finite-Diameter Well to and InstantaeousCharge of Water." Water Resources Research 3(1):263-269.

Dagan, G. 1967. "A Method of Determining the Permeability and Effective Porosity of Unconfined Anisotropic Aquifers." Water Resources Research 3:1059-1071.

Deju, R. A. 1974. The Hanford Field Testing Program. ARHC-00004-201, Atlantic Richfield Hanford Company, Richland, Washington.

DeLamare, M.A. 2000. Groundwater/Vadose Zone Integration Project Systems Engineering Management Plan. BHI-01347, Rev. 0, Bechtel Hanford, Inc., Richland, Washington.

Ferris, J.G., D.B. Knowles, R.H. Brown, and R.W. Stallman. 1962. Theory of Aquifer Tests. U.S.G.S. Water-Supply Paper 1536-E, U.S. Geological Survey, Washington, D.C.

Guyonnet D, S Mishra, J McCord. 1993. "Evaluating the Volume of Porous Medium Investigated During Slug Tests." Ground Water 31(4):627-633.

Hantush, M.S. 1962. "Drawdown Around a Partially Penetrating Well." Amer. Soc. Civil Engrs. Trans. 127:268-283.

Hartman, M. J., L. F. Morasch, and W. D. Webber, editors. 2002. Hanford Site Groundwater Monitoring for Fiscal Year 2001. PNNL-13788, Pacific Northwest National Laboratory, Richland, Washington.

Hvorslev, M.J. 1951. Time Lag and Soil Permeability in Groundwater Observations. U.S. Army Corps. of Engrs. Waterways Exper. Station Bull. 36, Vicksburg, Mississippi.

Hyder, Z., and J. J. Butler, Jr. 1995. "Slug Tests in Unconfined Formations: An Assessment of the Bouwer and Rice Technique." Ground Water 33(1):16-22. 
Karasaki, K., J. C. S. Long, and P. A. Witherspoon. 1988. “Analytical Models of Slug Tests.” Water Resources Research 24(1):115-126.

Kipp, K.L. 1973. "Unsteady Flow to a Partially Penetrating Finite Radius Well in an Unconfined Aquifer." Water Resources Research 9:448-462.

Kipp, K. L., and R. D. Mudd. 1973. Collection and Analysis of Pump Test Data for

Transmissivity Values. BNWL-1709, Battelle, Pacific Northwest National Laboratory, Richland, Washington.

Liu, W. Z., and J. J. Butler, Jr. 1995. The KGS Model for Slug Tests in Partially Penetrating Wells (Version 3.0). Kansas Geological Survey Computer Series Report 95-1, Lawrence, Kansas.

Moench AF and PA Hsieh. 1985. "Analysis of Slug Test Data in a Well with Finite-Thickness Skin.” In Memoirs Hydrogeology of Rocks of Low Permeability, January 7-12, 1985, Tucson, Arizona; International Association of Hydrogeologists, 17(1):17-29.

Moench, A. F., 1997. "Flow to a Well of Finite Diameter in a Homogeneous, Anisotropic WaterTable Aquifer." Water Resources Research 33(6):1397-1407.

Neuman, S.P. 1974. "Effect of Partial Penetration on Flow in Unconfined Aquifers Considering Delayed Gravity Response.” Water Resources Research 10:303-312

Neuman, S.P. 1975. “Analysis of Pumping Test Data from Anisotropic Unconfined Aquifers Considering Delayed Gravity Response.” Water Resources Research 11:329-342.

Newcomb, R. C., J. R. Strand, and F. J. Frank. 1972. Geology and Ground-Water Characteristics of the Hanford Reservation of the U.S. Atomic Energy Commission, Washington. Professional Paper 717, U.S. Geological Survey, Washington, D.C.

Newcomer, D. R. 1990a. Unconfined Aquifer Hydrologic Test Data Package for the 200 West Groundwater Aggregate Area Management Study. WHC-SD-EN-DP-029, Rev. 0, Westinghouse Hanford Company, Richland, Washington.

Newcomer, D. R. 1990b. Unconfined Aquifer Hydrologic Test Data Package for the 200 East Groundwater Aggregate Area Management Study. WHC-SD-EN-DP-030, Rev. 0, Westinghouse Hanford Company, Richland, Washington.

Rasmussen, T. C., and L. A. Crawford. 1997. "Identifying and Removing Barometric Pressure Effects in Confined and Unconfined Aquifers." Ground Water 35(3):502-511.

Spane, F. A. Jr. 1992. Applicability of Slug Interference Tests Under Hanford Site Test Conditions: Analytical Assessment and Field Evaluation. PNL-8070, Pacific Northwest National Laboratory, Richland, Washington.

Spane, F. A., Jr. 1993. Selected Hydraulic Test Analysis Techniques for Constant-Rate Discharge Tests. PNL-8539, Pacific Northwest National Laboratory, Richland, Washington.

Spane, F. A., Jr. 1996. "Applicability of Slug Interference Tests for Hydraulic Characterization of Unconfined Aquifers:(1) Analytical Assessment." Ground Water 34(1):66-74. 
Spane, F. A., Jr., and P. D. Thorne. 1995. Comparison of Constant-Rate Pumping Test and Slug Interference Test Results at the B-Pond Multi-Level Test Facility, Hanford Site. PNL-10835.

Pacific Northwest National Laboratory, Richland, Washington.

Spane, F. A., Jr., and P. D. Thorne. 2000. Analysis of the Hydrologic Response Associated with Shutdown and Restart of the 200-ZP-1 Pump and Treat System. PNNL-13342. Pacific Northwest National Laboratory, Richland, Washington.

Spane F. A., Jr., P. D. Thorne and D. R. Newcomer. 2001a. Results of Detailed Hydrologic Characterization Tests Fiscal Year 1999. PNNL-13378. Pacific Northwest National Laboratory, Richland, Washington.

Spane F. A., Jr., P. D. Thorne and D. R. Newcomer. 2001b. Results of Detailed Hydrologic Characterization Tests Fiscal Year 2000. PNNL-13514. Pacific Northwest National Laboratory, Richland, Washington.

Theis, C.V. 1935. "The Relation Between the Lowering of the Piezometric Surface and the Rate and Duration of Discharge of a Well Using Groundwater Storage." Trans. Amer. Geophysical. Union 16:519-524.

Thorne, P. D., and D. R. Newcomer. 1992. Summary and Evaluation of Available Hydraulic Property Data for the Hanford Site Unconfined Aquifer System. PNL-8337, Pacific Northwest National Laboratory, Richland, Washington.

Walter, G.R., and G.M. Thompson. 1982. "A Repeated Pulse Technique for Determining the Hydraulic Properties of Tight Formations." Ground Water 20(2):186-193.

Weeks, E. P. 1979. "Barometric Fluctuations in Wells Tapping Deep Unconfined Aquifers." Water Resources Research 15(5):1167-1176. 
Appendix A : Prototype Saturated Zone Hydraulic Properties Database 



\section{APPENDIX A}

\section{PROTOTYPE DATABASE OF SATURATED ZONE HYDRAULIC PROPERTIES FOR THE HANFORD SITE}

The eight tables in this appendix list data and information from the current prototype database of saturated zone hydraulic properties. Columns for the "well name", "test start date", and "sequence" (for more than one test or analysis) are listed in each table. Taken together, these fields uniquely identify each test and analysis.

Information contained in these tables is preliminary and additional information is being added to the spreadsheet as part of the ongoing database development. This includes the addition of available test information for the listed tests and addition of tests that are not yet included in the database. No "quality flag" information has been assigned at this point. 


\begin{tabular}{|c|c|c|c|c|c|c|c|c|c|c|c|c|c|}
\hline 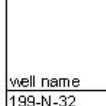 & $\begin{array}{l}\text { test tart } \\
\text { date } \\
3.2619984\end{array}$ & sequence & $\begin{array}{c}\text { test type } \\
\text { (oontart } \\
\text { rateistepislug) } \\
\text { constant rate }\end{array}$ & $\begin{array}{l}\text { aquifertype } \\
\text { (unconfined, } \\
\text { confined) } \\
\text { unomfined }\end{array}$ & \begin{tabular}{|l} 
single or \\
mutitiple we \\
(single or \\
muthiple)
\end{tabular} & hydrogeologic unit tested & $\begin{array}{c}\text { maximum head } \\
\text { change at stress } \\
\text { mell [m] }\end{array}$ & analysismethod & $\begin{array}{c}\text { barometric } \\
\text { effects } \\
\text { rem oved } \\
\text { (yes or no) } \\
\end{array}$ & \begin{tabular}{|c} 
analysis \\
date
\end{tabular} & quality flag & reference / source & data location \\
\hline$\frac{1999-N-32}{299-E 18-1}$ & $\begin{array}{l}3 / 26,1984 \\
8 / 3 / 1988\end{array}$ & a & $\frac{\text { constant rate }}{\text { constant rate }}$ & unoonfined & \begin{tabular}{|l} 
multiple \\
single \\
\end{tabular} & Han ford fom ation Unit 1 & 0.9 & $\begin{array}{l}\text { Theis recovery method } \\
\text { Cooper and Jacobot (1946) sem ilog } \\
\text { treipthine methos }\end{array}$ & no & & & PNL-8335 & PNL-7468 \\
\hline \begin{tabular}{|l|}
$299-E 18-1$ \\
$209-F 19-1$
\end{tabular} & $8,3 / 988$ & $\mathrm{~b}$ & constant rate & unoonfined & single & Hanford fom ation Unit 1 & 0.9 & Theis type-curve & no & & & PNL-7468 & PNL-7468 \\
\hline 299-E18-1 & $8 / 3 / 1988$ & & $\begin{array}{cc}\text { constant rate } \\
\text { nate }\end{array}$ & unconfined & single & Han ford form ation Unit 1 & 0.9 & $\begin{array}{l}\text { Cooper and Jaaoos (1946) sem ilog } \\
\text { sraiaghtine method }\end{array}$ & no & & & PNL-7468 & PNL-7468 \\
\hline \begin{tabular}{|l|l|}
$299-E 18-2$ \\
\end{tabular} & $11 / 4 / 988$ & & constant rate & unoon fined & single & Han ford form ation Unit 1 & 0.55 & $\begin{array}{l}\text { Cooper and Jacoob (1946) semilog } \\
\text { straightline method }\end{array}$ & no & & & PNL-7468 & PNL-7468 \\
\hline 299-E18-3 & $8 M 2 M 988$ & a & $\begin{array}{lc}\text { constant rate } \\
\text { s. }\end{array}$ & unmoninert & multiple & Han ford fom ation Unit 1 & 0.88 & Cooper and Jaoob (1946) sem ilog & no & & & PNL-7468 & PNL-7468 \\
\hline 299-E18-3 & $8 / 2 / 1988$ & $\mathrm{~b}$ & constant rate & unomn fined & $\begin{array}{l}\text { multiple } \\
\text {. }\end{array}$ & Han ford form ation Unit 1 & 0.88 & 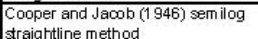 & no & & & PNL-7468 & PNL-7468 \\
\hline 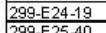 & $10 / 2 \mathrm{M} 989$ & & suga & unconfined & single & Hanford fom ation Unit 1 & 0.49 & Boumer and Rioe & no & & & PNL-7330 & PNL-7330 \\
\hline $\begin{array}{l}\frac{299-E 2540}{299-E 541} \\
2954\end{array}$ & 9:2919899 & & $\frac{\text { sugg }}{s+102}$ & unoonfined & $\begin{array}{ll}\text { single } \\
\text { single }\end{array}$ & $\begin{array}{l}\text { Hanford fom attion Unit } 1 \\
\text { Hentort }\end{array}$ & 0.4 & Boumer and Rice & no & & & PNN-7330 & PNL-7330 \\
\hline$\frac{\mid 39-29-5+1}{299-E 26-9}$ & 8034319990 & & sugg & 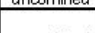 & $\begin{array}{l}\frac{s_{\text {sigigle }}}{\text { single }} \\
\text {. }\end{array}$ & Han ford form ation Unit 1 & $\frac{1}{0.43}$ & $\begin{array}{l}\text { Doumer and Rice } \\
\text { Boumer and Rice }\end{array}$ & $\frac{n o}{n o}$ & & & 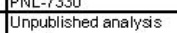 & WiHC-MR - 0235 \\
\hline $299-E 26-11$ & 82814990 & & sug & Uniosninied & single & Han ford form ation Unit 1 & 0.5 & Boumer and Rice & no & & & Unpoublished analysis & WHC-MR-0235 \\
\hline $299-E 27-8$ & $8 / 991987$ & & $\begin{array}{c}\text { constant rate } \\
\text { nate }\end{array}$ & andontmiteat & single & & 0.04 & Cooper and Jacosb sem ilog & no & & & PNL-6820, vol. 1 and 2 & $\overline{\text { PNL-6820, vol. } 2}$ \\
\hline $299-\mathrm{E} 27-9$ & $845 / 987$ & & constant rate & & single & & 1.86 & 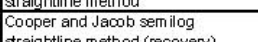 & no & & & PNL-6820, vol. 1 and 2 & PNL-6820, vol. 2 \\
\hline $299-E 27-10$ & $8 / 1 / 1987$ & & constant rate & & multiple & & 0.59 & 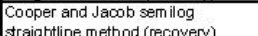 & no & & & PNL-6820, wol. 1 and 2 & PNL-6820, vol. 2 \\
\hline $\begin{array}{ll}299-E 27-13 \\
299-27-14\end{array}$ & $\frac{102001989}{10020499}$ & & $\frac{\text { sug }}{\text { sish }}$ & $\begin{array}{l}\text { unoonfined } \\
\text { unomfinet }\end{array}$ & $\begin{array}{ll}\text { single } \\
\text { single }\end{array}$ & 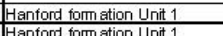 & 0.33 & $\begin{array}{l}\text { Eoumer and Rioe } \\
\text { Eoum }\end{array}$ & no & & & $\frac{P N L-7330}{P N A-730}$ & $\frac{P N L-7330}{P \text { PNA.730 }}$ \\
\hline $\begin{array}{ll}299-E T / 14 \\
299-E 27-15 \\
\end{array}$ & $\begin{array}{ll}1012019695 \\
10491989\end{array}$ & & $\begin{array}{ll}\text { ssugg } \\
\text { sug }\end{array}$ & $\begin{array}{l}\text { uniosininea } \\
\text { unoon fined }\end{array}$ & 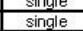 & Hanford form ation Unitit 1 & 0.37 & $\begin{array}{l}\text { Boumer and Rioe } \\
\text { Boumer and Riose }\end{array}$ & $\frac{n o}{\text { no }}$ & & & 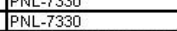 & 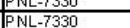 \\
\hline $299-E 28-27$ & 9:29/1987 & & $\begin{array}{lc}\text { constant rate } \\
\text { nate }\end{array}$ & unmonfoed & single & & 0.03 & 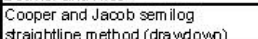 & no & & & PNL-6820, vol. 1 and 2 & PNL-6820, vol. 2 \\
\hline $299-E 324$ & 9:21/1987 & & constant rate & unomenfined & single & & 3.6 & $\begin{array}{l}\text { Cooper and Jacoob sem ilog } \\
\text { strainhtine method ddraundown }\end{array}$ & no & & & PNL-6820, vol. 1 and 2 & PNL-6820, vol. 2 \\
\hline $299-E 32-5$ & 84134990 & & sug & unconnfined & single & Hanford fom ation Unit 1 & 0.25 & 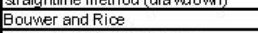 & no & & & \begin{tabular}{|l|l|l} 
PNL-73333 \\
\end{tabular} & PNL-7333 \\
\hline $299-E 33-28$ & 10,21 19987 & & constant rate & unmoninest & single & & 0.02 & Cooper and Jacobs sem ilog & no & & & PNL-6820, vol. 1 and 2 & PNL-6820, vol. 2 \\
\hline $299-\mathrm{E} 33-29$ & $947 / 1987$ & & constant rate & unmonfined & single & & 0.03 & $\begin{array}{l}\text { Copper and Jacobo sem ilog } \\
\end{array}$ & no & & & PNL-6820, wol. 1 and 2 & PNL-6820, vol. 2 \\
\hline $299-\mathrm{E} 33-30$ & $9 / 24 / 9987$ & & $\begin{array}{c}\text { constant rate } \\
\text { s. }\end{array}$ & unoonfined & single & & 0.01 & 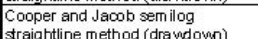 & no & & & PNL-6820, vol. 1 and 2 & PNL-6820, vol. 2 \\
\hline $299-E 33,33$ & $9: 27 / 1989$ & & sug & unoon fined & single & Hanford fom ation Unit 1 & 0.37 & 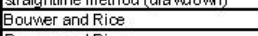 & no & & & PNL-7330 & PNL-7330 \\
\hline $299-E 33-44$ & $1043 / 998$ & $a$ & $\frac{\text { sug }}{\text { sing }}$ & unoonfined & $\frac{\text { single }}{\text { single }}$ & & $\begin{array}{c}1.117 \\
1117 \\
\end{array}$ & $\begin{array}{l}\text { Boumer and Rices } \\
\text { Twerise }\end{array}$ & & & & PNNL-13378 & \\
\hline $\begin{array}{l}\frac{299-E 3344}{299-333-334} \\
22\end{array}$ & 10/3/3998 & $\frac{b}{a}$ & $\frac{\text { sug }}{\text { sug }}$ & unoonfined & $\frac{\text { single }}{\text { single }}$ & & $\frac{1.117}{1.117}$ & $\begin{array}{l}\text { Type-Curve } \\
\text { Boumer and Rioe }\end{array}$ & & & & $\begin{array}{l}\text { PNNLL13378 } \\
\text { PNNL-13514 }\end{array}$ & Sigma V, Room \\
\hline $299-$-E33-334 & $2 \pi / 2000$ & $\mathrm{~b}$ & sug & unopofined & single & & 1.117 & Type-Curve & & & & PNNLL-13514 & Sigma V, Room \\
\hline $299-E 33-335$ & $3: 2822000$ & a & sug & unoon fined & single & & 1.117 & Boumer and Rios & & & & PNNL-13514 & $\begin{array}{l}\text { Sigma V, Room } \\
2606\end{array}$ \\
\hline $299-E 33-335$ & $3 / 2822000$ & $\mathrm{~b}$ & sug & unoonfined & single & & 1.117 & Type-Curve & & & & PNNLL-13514 & $\begin{array}{l}\text { Sigma V, Room } \\
\text { S2006 }\end{array}$ \\
\hline 299-E34-2 & $87 / 1987$ & a & constant rate & unoon fined & muttiple & & 0.18 & 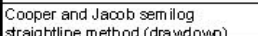 & no & & & PNL-6820, vol. 1 and 2 & PNL-6820, vol. 2 \\
\hline 299-E34-2 & $87 / 1987$ & $\mathrm{~b}$ & constart rate & unomfined & $\begin{array}{l}\text { muttiple } \\
\text { mats }\end{array}$ & & 0.18 & $\begin{array}{l}\text { Cooper and Jacobs sem liog } \\
\text { sraightline method (recovery) }\end{array}$ & no & & & PNL-6820, vol. 1 and 2 & PNL-6820, vol. 2 \\
\hline $299-\mathrm{E} 34-3$ & $815 / 1987$ & a & $\begin{array}{c}\text { constant rate } \\
\text { nate }\end{array}$ & unoonfined & single & & 0.55 & Cooper and Jacob semilog & no & & & PNL-6820, vol. 1 and 2 & PNL-6820, vol. 2 \\
\hline $299-E 34-3$ & $85 / 5987$ & $\mathrm{~b}$ & constant rate & unoon fined & single & & 0.55 & $\begin{array}{l}\text { Cooper and Jacob sem lilog } \\
\text { straightine method (recovery) }\end{array}$ & no & & & PNL-6820, vol. 1 and 2 & PNL-6820, vol. 2 \\
\hline $\begin{array}{l}299-E 34-7 \\
299-E 35-2 \\
\end{array}$ & $\begin{array}{l}10 / 51989 \\
8 / 1 / 3 / 990\end{array}$ & & $\frac{\text { sug }}{\text { sug }}$ & $\begin{array}{l}\text { uncosn fined } \\
\text { unomntined }\end{array}$ & $\begin{array}{l}\text { single } \\
\text { single }\end{array}$ & $\begin{array}{l}\text { Hanford fom ation Unit } 1 \\
\text { Han ford fom attion Unit } 1\end{array}$ & $\frac{0.83}{1.09}$ & \begin{tabular}{|l} 
Boumer and Rios \\
Boumer and Rioe
\end{tabular} & $\frac{\text { no }}{\text { no }}$ & & & $\begin{array}{l}\text { PNNL-7333 } \\
\text { Wuppublished analysis } \\
\text { report }\end{array}$ & PNL-7333 \\
\hline
\end{tabular}

Table A.1 Stress Well Test and Analysis Data 


\begin{tabular}{|c|c|c|c|c|c|c|c|c|c|c|c|c|c|}
\hline mell name & $\begin{array}{c}\text { test start } \\
\text { date }\end{array}$ & sequence & $\begin{array}{c}\text { test type } \\
\text { (oconsant } \\
\text { rateistepistug) }\end{array}$ & $\begin{array}{l}\text { aquifer type } \\
\text { (unconfined, } \\
\text { confined) }\end{array}$ & $\begin{array}{l}\text { single or } \\
\text { muttiple mel } \\
\text { (single or } \\
\text { multiple) * }\end{array}$ & hydrogeologic unit tested & $\begin{array}{c}\text { maximum head } \\
\text { change at stress } \\
\text { mell [m] }\end{array}$ & analysism method & $\begin{array}{l}\text { barometric } \\
\text { effects } \\
\text { rem oved } \\
\text { (yes or no) }\end{array}$ & $\begin{array}{c}\text { analysis } \\
\text { date }\end{array}$ & quality flag & reference / source & data location \\
\hline $299-M 6-2$ & & & constant rate & unoonfined & single & & & $\begin{array}{l}\text { Cooper and Jaoob sem ilog } \\
\text { straightline method (dra wdown) }\end{array}$ & & & & PNL-6820, wol. 1 and 2 & PNL-6820, vol. 2 \\
\hline $299-W_{16-2}$ & $11 / 5 / 1987$ & & constant rate & unoonfined & single & & 4.2 & $\begin{array}{l}\text { Cooper and Jaoob sem ilog } \\
\text { sraightline method (recovery) }\end{array}$ & no & & & PNL-6820, wol. 1 and 2 & PNL-6820, vol. 2 \\
\hline $299-W / 7-1$ & \begin{tabular}{|l}
$7 / 15 / 9987$ \\
\end{tabular} & a & constant rate & unoon fined & multiple & & 1.2 & $\begin{array}{l}\text { Cooper and Jacoob sem ilog } \\
\text { sraightine method (drawdonn) }\end{array}$ & no & & & PNL-6820, wol. 1 and 2 & PNL-6820, vol. 2 \\
\hline $299-W / 1$ & \begin{tabular}{|l}
$7 / 15 / 1987$ \\
\end{tabular} & $\mathrm{~b}$ & constant rate & unoon fined & $\begin{array}{l}\text { muttiple } \\
\text {. }\end{array}$ & & 1.2 & $\begin{array}{l}\text { Cooper and Jacobos sem lilog } \\
\text { sraightline method (recovery) }\end{array}$ & no & & & PNL-6820, wol. 1 and 2 & PNL-6820, vol. 2 \\
\hline $299-W 7-2$ & $9 / 16 / 1987$ & a & constant rate & unmonfoed & multiple & & 1.6 & $\begin{array}{l}\text { Cooper and Jacob sem ilog } \\
\text { s. }\end{array}$ & no & & & PNL-6820, wol. 1 and 2 & PNL-6820, vol. 2 \\
\hline $299-W 7-2$ & 9/16/4987 & $\mathrm{b}$ & constant rate & unoponfined & muttiple & & 1.6 & 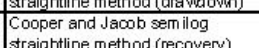 & no & & & PNL-6820, wol. 1 and 2 & PNL-6820, vol. 2 \\
\hline $299-W / 4$ & 11/12/4987 & a & constant rate & unoon fined & single & & 2.34 & $\begin{array}{l}\text { Cooper and dacobs sem liog } \\
\text { straightine method (dra wdown) }\end{array}$ & no & & & PNL-6820, wol. 1 and 2 & PNL-6820, vol. 2 \\
\hline $299-W / 4$ & $11 / 12 / 1987$ & $\mathrm{~b}$ & constant rate & uncosn fined & single & & 2.34 & Cooper and Jacobs sem ilog & no & & & PNL-6820, wol. 1 and 2 & PNL-6820, vol. 2 \\
\hline $299-W 7-5$ & $11 / 21 / 1987$ & & constant rate & unoonfined & single & & 1.53 & $\begin{array}{l}\text { Cooper and Jacobs semiliog } \\
\text { straightine method (drawdomn) }\end{array}$ & no & & & PNL-6820, wol. 1 and 2 & PNL-6820, vol. 2 \\
\hline $299-M 7-6$ & $10 / 4 / 1987$ & a & constant rate & unoonfined & single & & 6.5 & $\begin{array}{l}\text { Cooper and Jacobos sem iliog } \\
\text { sraightine method (drawdown) }\end{array}$ & no & & & PNL-6820, wol. 1 and 2 & PNL-6820, vol. 2 \\
\hline $299-W / 6$ & $10 / 4 / 1987$ & $\mathrm{~b}$ & constant rate & unoonfined & single & & 6.5 & $\begin{array}{l}\text { Cooper and Jacob sem ilog } \\
\text { sraightline method (recovery) }\end{array}$ & no & & & PNL-6820, wol. 1 and 2 & PNL-6820, vol. 2 \\
\hline$\frac{299-\sqrt[N]{ }-7}{299-1 / 8-1}$ & \begin{tabular}{|l|}
$1215 / 9899$ \\
$7 / 11 / 1987$ \\
\end{tabular} & & $\begin{array}{c}\frac{\text { sug }}{\text { constant rate }} \\
\text { sate }\end{array}$ & $\begin{array}{l}\text { unoon fined } \\
\text { unoon fined }\end{array}$ & $\begin{array}{l}\frac{\text { single }}{\text { single }} \\
\end{array}$ & & $\begin{array}{l}1.05 \\
7.36\end{array}$ & \begin{tabular}{|l|} 
Boumer and Rioe \\
Cooper and Jacoob sem ilog \\
straightline method (recovery)
\end{tabular} & $\begin{array}{l}\text { no } \\
\text { no }\end{array}$ & & & \begin{tabular}{|l} 
PNL-73333 \\
PNL-6820, wol. 1 and 2
\end{tabular} & $\frac{P N L-7333}{\text { PNL-6820, vol. } 2}$ \\
\hline $299-M / 19-1$ & $10 / 23 / 1987$ & a & sug & unmonfiner & single & & 1.1 & Boumer and Rioe & no & & & PNL-6820, wol. 1 and 2 & PNL-6820, vol. 2 \\
\hline $299-M 9-1$ & $10 / 23 / 1987$ & $\mathrm{~b}$ & sug & unoprfined & single & & 1.1 & Hworsev (1951) & no & & & PNL-6820, wol. 1 and 2 & PNL-6820, vol. 2 \\
\hline $299-W 10-13$ & 9/14/1987 & & constant rate & unoon fined & multiple & & 3.37 & $\begin{array}{l}\text { Cooper and Jacob sem ilog } \\
\text { staightline method (recovery) }\end{array}$ & no & & & PNL-6820, wol. 1 and 2 & PNL-6820, vol. 2 \\
\hline $299-1 M 10-14$ & $10 / 26 / 1987$ & & constant rate & unoonfined & multiple & Ringold Unit 5 & 8.39 & $\begin{array}{l}\text { Cooper and Jaoobb sem ilog } \\
\text { straightline method (recovery) }\end{array}$ & no & & & PNL-6820, wol. 1 and 2 & PNL-6820, vol. 2 \\
\hline 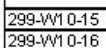 & \begin{tabular}{|l}
$11 / 3 / 1989$ \\
$10 / 30 / 1989$ \\
\end{tabular} & & siug & $\begin{array}{l}\text { unconfined } \\
\text { unon fined }\end{array}$ & $\begin{array}{l}\text { single } \\
\text { single }\end{array}$ & & $\begin{array}{l}0.6 \\
0.5\end{array}$ & \begin{tabular}{|l} 
Boumer and Rive \\
Boumer and Rioe \\
\end{tabular} & $\frac{\text { no }}{\text { no }}$ & & & $\frac{\text { PNLL-7330 }}{\text { PNL-7330 }}$ & $\frac{1}{\text { PNLL-7330 }}$ \\
\hline $299-1 / 10-17$ & $\mid \begin{array}{l}1 / 15 / 1991 \\
\end{array}$ & a & sug & unconfing & single & & 0.37 & Boumer and Rioe & no & & & $\begin{array}{l}\text { WHC-SD-EN-TI-014, } \\
\text { Rev, } 0\end{array}$ & $\begin{array}{l}\text { Airhart (1990) S-10 } \\
\text { borehole report }\end{array}$ \\
\hline $299-\times 10-17$ & 1/15/1991 & $\mathrm{b}$ & sug & unoonfined & single & & 0.66 & Boumer and Rioe & no & & & $\begin{array}{l}\text { WHC-SD-EN-TI-014, } \\
\text { Rev. } 0\end{array}$ & $\begin{array}{l}\text { Airhart (1990) S-10 } \\
\text { borehole reportt }\end{array}$ \\
\hline $299-M_{1} 0-18$ & 1M6M991 & & sug & unoonfined & single & & 0.45 & Boumer and Rioes & no & & & $\begin{array}{l}\text { WHC-SD-EN-TI-014, } \\
\text { ReV. } 0\end{array}$ & $\begin{array}{l}\text { Airhart (1990) S-10 } \\
\text { borehole report }\end{array}$ \\
\hline $299-1 / 10-23$ & 1884999 & a & sug & unconfined & single & & 1.117 & Boumer and Rice & & & & PNNLL-13378 & $\begin{array}{l}\text { Sigma V, Room } \\
2606\end{array}$ \\
\hline $299-1 \times 10-23$ & \begin{tabular}{|l|}
1881999 \\
\end{tabular} & $\mathrm{~b}$ & sug & unoon fined & single & & 1.117 & Type-Curve & & & & PNNL-13378 & $\begin{array}{l}\text { Sigma V, Room } \\
2606\end{array}$ \\
\hline $299-W 10-24$ & \begin{tabular}{|l|}
$1 / 11 / 1999$ \\
\end{tabular} & a & sug & unongfined & single & Ringold Unit 5 & 1.117 & Boumer and Rice & & & & PNNL-13378 & $\begin{array}{l}2000 \\
\text { Sigma V, Room } \\
26606\end{array}$ \\
\hline 299-W1 0-24 & 1/11/9999 & $\mathrm{b}$ & sug & unomfined & single & Ringold Unit 5 & 1.117 & Type-Curve & & & & PNNL-13378 & $\begin{array}{l}S_{2606} \\
2606, R o o m\end{array}$ \\
\hline $299-1 / 10-24$ & \begin{tabular}{|l}
$4 / 21 / 1999$ \\
\end{tabular} & & constant rate & unoonfined & multiple & Ringold Unit 5 & & Type-Curve & yes & & & PNNL-13378 & $\begin{array}{l}\text { Sigma V, Room } \\
2606\end{array}$ \\
\hline $299-W 10-26$ & $10 / 154998$ & $\mathrm{a}$ & sug & unoonfined & single & & 1.117 & Boumer and Rices & & & & PNNL-13378 & \\
\hline$\frac{2999-W 10-26}{299-M 10-26}$ & $\frac{10 / 5 / 1 / 998}{4 / 24 / 1999}$ & & $\frac{\text { sug }}{\text { constant rate }}$ & & $\frac{\text { singge }}{\text { mutiple }}$ & & & \begin{tabular}{|l|} 
Type-Curve \\
Type-Curve
\end{tabular} & yes & & & $\frac{\text { PNNLL-13378 }}{\text { PNNNL-13378 }}$ & sigmaV, Room \\
\hline 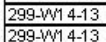 & $\frac{10 / 44 / 998}{10 / 44 / 998}$ & $\frac{a}{b}$ & $\frac{\text { slug }}{\text { sug }}$ & $\begin{array}{l}\text { unconfined } \\
\text { unoonfined }\end{array}$ & $\begin{array}{l}\text { single } \\
\text { single }\end{array}$ & $\begin{array}{l}\text { Ringold Unit 5 } \\
\text { Ringold Unit } 5 \\
\end{array}$ & $\frac{1.117}{1.117}$ & \begin{tabular}{|l} 
Eoumer and Rioe \\
Type-Curye
\end{tabular} & & & & $\frac{\mid \text { PNNL-13378 }}{\text { PNNL-13378 }}$ & \\
\hline
\end{tabular}




\begin{tabular}{|c|c|c|c|c|c|c|c|c|c|c|c|c|c|}
\hline mell name & $\begin{array}{c}\text { test tart } \\
\text { date }\end{array}$ & sequence & $\begin{array}{c}\text { test type } \\
\text { (constant } \\
\text { rateistepistug) }\end{array}$ & \begin{tabular}{|c}
$\begin{array}{c}\text { aquifer type } \\
\text { (unconfined, } \\
\text { confined) }\end{array}$ \\
cols
\end{tabular} & \begin{tabular}{|l} 
single or \\
muttiple wel \\
(single or \\
multiple) *
\end{tabular} & hydrogeologic unit tested & $\begin{array}{c}\text { maximum head } \\
\text { change at stress } \\
\text { well [m] }\end{array}$ & analysism method & $\begin{array}{l}\text { barometric } \\
\text { effects } \\
\text { rem oved } \\
\text { (yes or no) }\end{array}$ & $\begin{array}{c}\text { analysis } \\
\text { date }\end{array}$ & quality flag & I reference / source & data location \\
\hline $299-1 / 4-13$ & | 4/1/1999 & & & unoon fined & & Ringold Unit 5 & & |Type-Curve & & & & |PNNLL-13378 & $\mid \begin{array}{l}\text { Sigma V, Room } \\
2606\end{array}$ \\
\hline 299-WM 4-14 & $1 / 1 / 1 / 999$ & $\mathrm{~b}$ & sug & L o menoed & single & Ringold Unit 5 & 1.117 & Type-Curve & & & & PNNL-13378 & sigma V, Room \\
\hline 299-W15-15 & $8 / 21 / 1987$ & & \begin{tabular}{|l} 
constant rate \\
\end{tabular} & unomnfined & single & & 5.65 & Cooper and Jaoob semilog & no & & & PNL-6820, wol. 1 and 2 & $\frac{2606}{\text { PNL-6820, vol. } 2}$ \\
\hline 299-WM 5-16 & $8 / 20 / 987$ & a & \begin{tabular}{|l} 
constart rate \\
\end{tabular} & uncos fined & multiple & & 3.49 & $\begin{array}{l}\text { Cooper and Jacoos semilog } \\
\text { sraightine method (dra wdown) }\end{array}$ & no & & & PNL-6820, wol. 1 and 2 & PNL-6820, vol. 2 \\
\hline 299-W1 5-18 & $7 / 21 / 987$ & & \begin{tabular}{|c|} 
constart rate \\
\end{tabular} & uncon fined & multiple & & 2.1 & 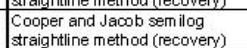 & no & & & PNL-6820, wol. 1 and 2 & PNL-6820, vol. 2 \\
\hline 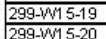 & $\begin{array}{l}10,3019989 \\
11 / 3989\end{array}$ & $a$ & \begin{tabular}{|l} 
sug \\
sug \\
\end{tabular} & \begin{tabular}{|l|l|} 
unconfined \\
unomfined \\
\end{tabular} & $\begin{array}{l}\frac{\text { single }}{\text { sinale }} \\
\end{array}$ & & $\begin{array}{l}0.63 \\
057\end{array}$ & 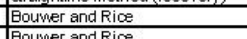 & no & & & 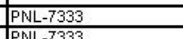 & PNL-7333 \\
\hline $299-1 / 15-20$ & \begin{tabular}{|l|l|}
113319899 \\
\end{tabular} & $\frac{a}{b}$ & sug & unoon fined & $\begin{array}{l}\text { silupe } \\
\text { single }\end{array}$ & & 0.57 & $\begin{array}{l}\text { Cooper and Jacosb semilog } \\
\text { straightine method }\end{array}$ & $\frac{100}{\text { no }}$ & & & PNL-7333 & PNL-7333 \\
\hline 299-:M 5-22 & 1/15/991 & a & sug & unoon fined & single & & $1.17 ?$ & Boumer and Rice & no & & & $\begin{array}{l}\text { MAC-SD-EN-TI-014, } \\
\text { ReY-0 }\end{array}$ & $\begin{array}{l}\text { Airhart (1990) S-10 } \\
\text { borehole report }\end{array}$ \\
\hline 299-WM 5-22 & 1/145M991 & $\mathrm{b}$ & sug & unoon fined & single & & 0.38 & Boumer and Rice & no & & & $\begin{array}{l}\text { MHC-SD-EN-TI-014, } \\
\text { ReY. } 0\end{array}$ & $\begin{array}{l}\text { Airhart (1990) S-10 } \\
\text { borehole report }\end{array}$ \\
\hline 299-WM15-41 & $5 / 10 / 2000$ & & \begin{tabular}{|l} 
constant rate \\
\end{tabular} & unominged & single & & & Type-Curve & yes & & & PNNL-13514 & $\frac{2606}{S_{2606}}$ \\
\hline $299-1 \times 18-21$ & $7 / 14 / 1987$ & $\mathrm{a}$ & \begin{tabular}{|c|} 
constant rate \\
\end{tabular} & unomnfined & muttiple & & 5.45 & Cooper and Jaoos semilog & no & & & PNL-6820, vol. 1 and 2 & PNL-6820, vol. 2 \\
\hline 299-WM1 8-21 & $7 / 44 / 987$ & $\mathrm{~b}$ & constant rate & unmoninert & muttiple & & 5.45 & Cooper and Jaoobb sem ilog & no & & & PNL-6820, wol. 1 and 2 & PNL-6820, vol. 2 \\
\hline 299-WM 8-22 & $8 / 26 / 987$ & & \begin{tabular}{|l} 
constant rate \\
\end{tabular} & Hungoneed & multiple & Ringold Unit 5 & 22.74 & 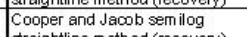 & no & & & PNL-6820, vol. 1 and 2 & PNL-6820, vol. 2 \\
\hline $299-1 \times 48-23$ & $6 / 22 / 987$ & a & \begin{tabular}{|l} 
constant rate \\
\end{tabular} & unomofined & single & & 0.79 & Cooper and Jaoos sem ilog & no & & & PNL-6820, wol. 1 and 2 & PNL-6820, vol. 2 \\
\hline $299-\$ M 18-23$ & $6 / 221987$ & $\mathrm{~b}$ & \begin{tabular}{|c|} 
constant rate \\
\end{tabular} & Lungonged & single & & 0.79 & 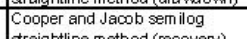 & no & & & PNL-6820, vol. 1 and 2 & PNL-6820, vol. 2 \\
\hline 299-W18-24 & $7 / 17 / 1987$ & & \begin{tabular}{|c|} 
constant rate \\
\end{tabular} & Hunonged & muttiple & & 0.51 & 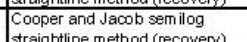 & no & & & PNL-6820, wol. 1 and 2 & PNL-6820, vol. 2 \\
\hline $299-1 \times 18-25$ & $12 / 12 / 4990$ & $a$ & sug & unoon fined & single & & 0.46 & Bouner and Rioe & no & & & $\begin{array}{l}\text { MAC-SD-EN-TI-014, } \\
\text { Rev. } 0\end{array}$ & \\
\hline $299-1 \times 18-25$ & 12 /12/1990 & $\mathrm{b}$ & sug & unoon fined & single & & 0.52 & Boumer and Rice & no & & & $\begin{array}{l}\text { WHC-SD-EN-T1-014, } \\
\text { Rev. } 0\end{array}$ & \\
\hline 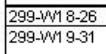 & \begin{tabular}{|l}
$\frac{11 / 22 / 1989}{1 / 17 / 9991}$ \\
\end{tabular} & a & $\begin{array}{l}\text { sugg } \\
\text { sug }\end{array}$ & unoon fined & $\begin{array}{l}\text { single } \\
\text { single }\end{array}$ & & $\begin{array}{l}0.46 \\
0.53\end{array}$ & \begin{tabular}{|l} 
Boumer and Rice \\
Boumer and Rice
\end{tabular} & $\begin{array}{l}\frac{n o}{n o} \\
\text { no }\end{array}$ & & & PNL-7333 & PNL-7333 \\
\hline
\end{tabular}





\begin{tabular}{|c|c|c|c|c|c|c|c|c|c|c|c|c|c|}
\hline Mell name & \begin{tabular}{|c|} 
test sart \\
date
\end{tabular} & sequence & $\begin{array}{c}\text { test type } \\
\text { (constart } \\
\text { rateistepisisug) }\end{array}$ & $\begin{array}{l}\text { aquitertype } \\
\text { (unconfined, } \\
\text { confined) }\end{array}$ & \begin{tabular}{|l} 
single or \\
multiple mel \\
(single or \\
multiple) *
\end{tabular} & hydrogeologic unit tested & $\begin{array}{c}\text { maximum head } \\
\text { change at stres } \\
\text { mell [m] }\end{array}$ & analysis method & \begin{tabular}{|l} 
barometric \\
effects \\
rem oved \\
(yes or no)
\end{tabular} & \begin{tabular}{|c|}
$\substack{\text { analysis } \\
\text { date }}$ \\
\end{tabular} & quality flag & reference / source & data location \\
\hline 299-W/23-15 & & a & sug & unoonfined & \begin{tabular}{|l|} 
single \\
\end{tabular} & & & |Boumer and Rioe & & & & PNNL-13514 & $\begin{array}{l}\text { Sigma V, Room } \\
2606\end{array}$ \\
\hline $299-W / 23-15$ & $1 / 24 / 2000$ & $\mathrm{~b}$ & sug & unomofined & single & & 1.117 & Type-Curve & & & & PNNL-13514 & $\begin{array}{l}\text { Sigma } \\
\text { sign, Room }\end{array}$ \\
\hline $299-W / 23-20$ & 11/1/2000 & a & sug & uncon fined & muttiple & & 1.117 & Boumer and Rice & & & & & $\begin{array}{l}\text { Sigoma V, Room } \\
2606\end{array}$ \\
\hline $299-\$ / 23-20$ & $11 / 1 / 2000$ & $\mathrm{~b}$ & sug & unoon fined & muttiple & & 1.117 & Type-Curve & & & & & $\begin{array}{l}\text { Sigma V, Room } \\
2606\end{array}$ \\
\hline $299-W / 23-21$ & 1/30/2001 & $a$ & sug & unoon fined & single & & 1.117 & Boumer and Rioe & & & & & $\begin{array}{l}\text { Sigma V, Room } \\
2606\end{array}$ \\
\hline $299-W / 23-21$ & $1 / 30 / 2001$ & $\mathrm{~b}$ & sug & unoon fined & single & & 1.117 & Type-Curve & & & & & $\begin{array}{l}\text { Sigma V, Room } \\
2606\end{array}$ \\
\hline $299-W 26-8$ & $5 / 31 / 1990$ & & sug & unconfined & single & & 0.56 & Boumer and Rios & no & & & $\begin{array}{l}\text { WHAC-SD-EN-TI-014, } \\
\text { Rev. } 0\end{array}$ & $\begin{array}{l}\text { Airhart (1990) S-10 } \\
\text { borehole report }\end{array}$ \\
\hline $299-N 26-9$ & $5 / 3 / 4990$ & & sug & unconfined & single & & 0.61 & Boumer and Rios & no & & & $\begin{array}{l}\text { WNCC-SD-EN-TI-014, } \\
\text { Rev. } 0 \text {, }\end{array}$ & $\begin{array}{l}\text { Airhant (1990) S-10 } \\
\text { borehole report }\end{array}$ \\
\hline |299-W26-10 & 5/31/1990 & & sug & unoonfined & single & & 0.55 & Boumer and Rice & no & & & $\begin{array}{l}\text { WNC-SD-EN-TI-014, } \\
\text { Rev. } 0\end{array}$ & 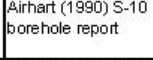 \\
\hline $299-W 26-11$ & $5 / 31 / 1990$ & a & sug & unconfined & single & & 0.67 & Boumer and Rios & no & & & $\begin{array}{l}\text { WNAC-SD-EN-TL-014, } \\
\text { Rev. } 0 \text {, }\end{array}$ & $\begin{array}{l}\text { Airhant (1990) S-10 } \\
\text { borehole report }\end{array}$ \\
\hline $299-W 26-11$ & $5 / 31 / 1990$ & $\mathrm{~b}$ & sug & unoonfined & single & & 0.6 & Boumer and Rioe & no & & & $\begin{array}{l}\text { WHC-SD-EN-TI-014, } \\
\text { ReV. }\end{array}$ & \begin{tabular}{|l|}
$\begin{array}{l}\text { Airhart (1990) S-10 } \\
\text { borehole report }\end{array}$ \\
bot
\end{tabular} \\
\hline $299-W 26-12$ & $5 / 10 / 990$ & a & sug & unconfined & single & & 0.32 & Boumer and Rios & no & & & $\begin{array}{l}\text { WHCC-SD-EN-TI-014, } \\
\text { Rev. } 0\end{array}$ & $\begin{array}{l}\text { Airhart (1990) S-10 } \\
\text { borehole report }\end{array}$ \\
\hline $299-W / 26-12$ & \begin{tabular}{|l|}
$510 M 990$ \\
\end{tabular} & $\mathrm{~b}$ & sug & unoonfined & single & & 0.58 & Boumer and Rios & no & & & $\begin{array}{l}\text { MNAC-SD-EN-TL-014, } \\
\text { Rev. } 0\end{array}$ & \begin{tabular}{|l}
$\begin{array}{l}\text { Airhart (1990) S-10 } \\
\text { borehole report }\end{array}$ \\
bot
\end{tabular} \\
\hline $299-W_{2} 6-13$ & $1 / 25 / 2000$ & a & sug & unoon fined & single & & 1.117 & Boumer and Rice & & & & PNNLL-13514 & $\begin{array}{l}\text { Sigma V, Room } \\
2606\end{array}$ \\
\hline $299-W 26-13$ & $1 / 25 / 2000$ & $\mathrm{~b}$ & slug & uncon fined & single & & 1.117 & Type-Curve & & & & PNNL-13514 & $\begin{array}{l}\text { Sigma a , Room } \\
2606\end{array}$ \\
\hline $399-1-9$ & 3/2/1987 & & constant rate & unoon fined & muttiple & & 24.58 & $\begin{array}{l}\text { Cooper and Jaoob straightline } \\
\text { semilog method (recovery) }\end{array}$ & no & & & PNL-6716 & PNL-6716 \\
\hline $399-1-10$ & $11 / 25 / 986$ & a & constant rate & unoonfined & single & & 0.72 & $\begin{array}{l}\text { Cooper and Jacobb straightiline } \\
\text { semilog method (drawdounn) }\end{array}$ & no & & & PNL-6716 & PNL-6716 \\
\hline$\frac{399-1-10}{399-1-10}$ & 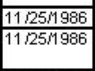 & $\frac{b}{c}$ & \begin{tabular}{|l} 
constant rate \\
constart rate \\
\end{tabular} & \begin{tabular}{|l} 
uncoonfined \\
unoonfined \\
\end{tabular} & $\begin{array}{l}\frac{\text { single }}{\text { single }} \\
\end{array}$ & & $\frac{0.72}{0.72}$ & 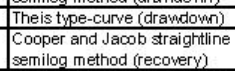 & $\frac{\text { no }}{\text { no }}$ & & & $\frac{\text { PNL-6716 }}{\text { PNL-6716 }}$ & $\frac{P N L-6716}{\text { PNL-6716 }}$ \\
\hline $399-1-13$ & \begin{tabular}{|l|}
$11 / 5 / 1986$ \\
\end{tabular} & a & constant rate & unoon fined & single & & 0.29 & $\begin{array}{l}\text { Cooper and Jacobt straightiline } \\
\text { semilog method (drandolown) }\end{array}$ & no & & & PNL-6716 & PNL-6716 \\
\hline 399-1-13 & $1115 / 986$ & $b$ & \begin{tabular}{|l} 
constant rate \\
\end{tabular} & $\begin{array}{ll}\text { uncoonfined } \\
\end{array}$ & single & & 0.29 & Theis type-curve (draindomolom) & no & & & PNL-6716 & PNL-6716 \\
\hline 399-1-13 & $1115 / 986$ & c & constant rate & unoon fined & single & & 0.29 & $\begin{array}{l}\text { Cooper and Jacobb straightline } \\
\text { semilog method (recovery) }\end{array}$ & no & & & PNL-6716 & PNL-6716 \\
\hline 399-1-14 & $11 / 12 / 986$ & & \begin{tabular}{|c|} 
constart rate \\
\end{tabular} & unoon fined & single & & 0.6 & 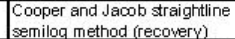 & no & & & PNL-6716 & PNL-6716 \\
\hline $399-1-16 \mathrm{~A}$ & \begin{tabular}{|l|l|}
$2 / 26 / 4987$ \\
304097
\end{tabular} & a & \begin{tabular}{|l} 
constant rate \\
\end{tabular} & $\begin{array}{l}\text { unoonfined } \\
\end{array}$ & muttiple & & 0.5 & $\begin{array}{l}\text { Theis thpe-curve (draindomn) } \\
\end{array}$ & no & & & PNL-6716 & PNL-6716 \\
\hline 399-1-16A & $2 / 26 / 1987$ & $\mathrm{~b}$ & \begin{tabular}{|l} 
constant rate \\
\end{tabular} & unomofined & multiple & & 0.5 & Cooper and Jaoob straightine & no & & & PNL-6716 & PNL-6716 \\
\hline 399-1-16. & \begin{tabular}{|l|}
$2 / 26 / 1987$ \\
\end{tabular} & c & \begin{tabular}{|l} 
constart rate \\
\end{tabular} & unconfined & muttiple & & 0.5 & $\begin{array}{l}\text { Cooper and Jacobb straightine } \\
\text { semilog method (recovery) }\end{array}$ & no & & & PNL-6716 & PNL-6716 \\
\hline 399-1-168 & 249 1987 & a & constant rate & unconfined & muttiple & & 4.4 & Theis type-curve (draindown) & no & & & PNL-6716 & PNLL6716 \\
\hline $399-1-168$ & $2 / 19 / 1987$ & $\mathrm{~b}$ & \begin{tabular}{|c|} 
constant rate \\
\end{tabular} & unoonfined & muttiple & & 4.4 & $\begin{array}{l}\text { Cooper and Jaoob straightine } \\
\text { semilog method (draudown) }\end{array}$ & no & & & PNL-6716 & PNL-6716 \\
\hline 399-1-16日 & 2 2/24/1987 & a & constant rate & unoon fined & muttiple & & 8.59 & Theis type-curve (reocovery) & no & & & PNL-6716 & PNL-6716 \\
\hline
\end{tabular}




\begin{tabular}{|c|c|c|c|c|c|c|c|c|c|c|c|c|c|}
\hline nell name & $\begin{array}{c}\text { test start } \\
\text { date }\end{array}$ & sequence & $\begin{array}{c}\text { test type } \\
\text { (constant } \\
\text { rateistepisiug) }\end{array}$ & $\begin{array}{l}\text { aquifer type } \\
\text { (unconfined, } \\
\text { confined) }\end{array}$ & $\begin{array}{l}\text { single or } \\
\text { multiple we } \\
\text { (single or } \\
\text { multiple) * }\end{array}$ & hydrogeologic unit tested & $\begin{array}{c}\text { maximum head } \\
\text { change at stress } \\
\text { mell [m] }\end{array}$ & analysismethod & \begin{tabular}{|c} 
barometric \\
effects \\
rem oved \\
(yes or no)
\end{tabular} & \begin{tabular}{c|} 
analysis \\
date
\end{tabular} & quality flag & reference / sounce & data location \\
\hline 399-1-168 & $2 / 24 / 1987$ & $\mathrm{~b}$ & \begin{tabular}{|l} 
constant rate \\
\end{tabular} & unoonfined & multiple & & 8.59 & Cooper and Jacob straightline & no & & & PNL-6716 & PNL-6716 \\
\hline $399-1-16 C$ & $2 M 7 / M 987$ & $a$ & constant rate & $\begin{array}{ll}\text { unoonfined } \\
\end{array}$ & muttiple & & 12.81 & Theis type-curve (dramdown) & no & & & PNL-6716 & PNL-6716 \\
\hline $399-1-16 \mathrm{C}$ & $2 / 17 / 19987$ & $\frac{\mathrm{a}}{\mathrm{b}}$ & constant rate & unconfined & muttiple & & 12.81 & $\begin{array}{l}\text { Cooper and Jacobs straightline } \\
\text { semilog method (dramdown) }\end{array}$ & no & & & PNL-6716 & PNL-6716 \\
\hline $399-1-16 \mathrm{C}$ & 2 2M7/M987 & $\bar{c}$ & constant rate & unoonfined & muttiple & & 12.81 & $\begin{array}{l}\text { Cooper and Jacosb straightline } \\
\text { semilog method (recovery) }\end{array}$ & no & & & PNL-6716 & PNL-6716 \\
\hline $399-1-178$ & $2 / 9 / 1987$ & a & constant rate & unoonfined & muttiple & & 12.81 & Theis type-curve (drawdomn) & no & & & PNL-6716 & PNL-6716 \\
\hline $399-1-178$ & $29 / 1987$ & $\mathrm{~b}$ & constant rate & unoonfined & multiple & & 12.81 & $\begin{array}{l}\text { Cooper and Jacobb straightline } \\
\text { semilog method draindono? }\end{array}$ & no & & & PNL-6716 & $\begin{array}{l}\text { PNL-6716 } \\
\end{array}$ \\
\hline 399-1-17日 & $29 / 987$ & $\mathrm{c}$ & constant rate & unoon fined & muttiple & & 12.81 & $\begin{array}{l}\text { Cooper and Jacob straightline } \\
\text { semilog method (recovery) }\end{array}$ & no & & & PNL-6716 & \begin{tabular}{|l|l|} 
PNL-6716 \\
\end{tabular} \\
\hline $399-1-17 \mathrm{C}$ & $2 / 1 / 1987$ & a & constant rate & $\begin{array}{ll}\text { unoonfined } \\
\end{array}$ & multiple & & 6.3 & Theis type-curve (dramdown) & no & & & PNL-6716 & PNL-6716 \\
\hline $399-1-17 \mathrm{C}$ & $2 / 11 / 1987$ & $\frac{\mathrm{b}}{\mathrm{b}}$ & $\begin{array}{l}\text { constant rate } \\
\end{array}$ & unoon fined & multiple & & 6.3 & $\begin{array}{l}\text { Cooper and Jacobs straightline } \\
\text { semilog method (drawdown) }\end{array}$ & $\frac{\text { no }}{\text { no }}$ & & & PNL-6716 & $\begin{array}{l}\text { PNL-6716 } \\
\text { PND }\end{array}$ \\
\hline $399-1-17 \mathrm{C}$ & $2 / 11 M 987$ & $\bar{c}$ & constant rate & unoonfined & muttiple & & 6.3 & $\begin{array}{l}\text { Cooper and Jacobs straightline } \\
\text { semilog method (recovery) }\end{array}$ & no & & & PNL-6716 & PNL-6716 \\
\hline $\begin{array}{l}\frac{399-1-18 \mathrm{~A}}{399-1-18 \mathrm{~A}} \\
\end{array}$ & $\frac{11 / 11 / 1986}{11 / 11 / 1986}$ & $\frac{a}{b}$ & $\begin{array}{l}\text { constant rate } \\
\text { constant rate }\end{array}$ & $\begin{array}{l}\text { unoonfined } \\
\text { unoonfined }\end{array}$ & $\frac{\text { single }}{\text { single }}$ & & $\begin{array}{l}0.09 \\
0.09\end{array}$ & $\begin{array}{l}\text { Theis type-curve (draindown) } \\
\text { Cooper and Jacob straightline } \\
\text { semilog method (draindown) }\end{array}$ & $\frac{\text { no }}{\text { no }}$ & & & \begin{tabular}{|l} 
PNL-6716 \\
PNL-6716
\end{tabular} & $\begin{array}{l}\text { PNLL-6716 } \\
\text { PNL-6716 }\end{array}$ \\
\hline $399-1-18 \mathrm{~B}$ & $1 / 29 / 987$ & a & constant rate & unoonfined & muttiple & & 7.89 & $\begin{array}{l}\text { Cooper and Jacoob straightline } \\
\text { semilog method (draindown) }\end{array}$ & no & & & PNL-6716 & PNL-6716 \\
\hline $\begin{array}{ll}399-1-18 \mathrm{~B} \\
39-190\end{array}$ & $1 / 29 / 987$ & $\mathrm{~b}$ & constant rate & unoonfined & multiple & & 7.89 & Theis type-curve (drandown) & no & & & PNL-6716 & PNL-6716 \\
\hline $\begin{array}{l}399-1-18 \mathrm{C} \\
399-1-18 \mathrm{C}\end{array}$ & \begin{tabular}{|l|}
$2 / 3 / 987$ \\
$23 / 3987$
\end{tabular} & $\frac{a}{b}$ & $\begin{array}{l}\text { constant rate } \\
\text { constant rate }\end{array}$ & unconfined & $\begin{array}{l}\frac{\text { multiple }}{\text { mutiple }} \\
\end{array}$ & & $\begin{array}{l}10.35 \\
10.35\end{array}$ & $\begin{array}{l}\text { Theis type-curve (drawdown) } \\
\text { Cooper and Jacob straightline }\end{array}$ & $\frac{\mathrm{no}}{\mathrm{no}}$ & & & $\frac{\text { PNLL-6716 }}{\text { PNL-6716 }}$ & $\begin{array}{l}\text { PNL-6716 } \\
\text { PNL-6716 }\end{array}$ \\
\hline $399-1-18 \mathrm{C}$ & $2 / 3 / 1987$ & c & constant rate & 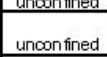 & muttiple & & 10.35 & 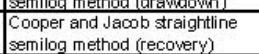 & no & & & PNL-6716 & $\begin{array}{l}\text { PNL-6716 } \\
\end{array}$ \\
\hline 699-S22-E9A & $1 / 2 M 992$ & & sug & & single & & & Boumer and Rice & & & & $\begin{array}{l}\text { WHC-SD-EN-T1-052, } \\
\text { Rev. 0 }\end{array}$ & \\
\hline 699-S22-E9D & $4 / 14 / 1992$ & & sing & & muttiple & & 0.54 & Boumer and Rice & & & & MHC-SD-EN-TI-052, & \\
\hline 699-S27 E9A & $1 / 141992$ & & step & unconfined & single & & 1.7 & Domenio and Schmartz (1990) & no & & & $\begin{array}{l}\text { WHC-SD-EN-T1-052, } \\
\text { Rev. } 0\end{array}$ & \\
\hline & $10 M 992$ & & sug & unomnfined & single & & & Pouner and Bise & $m$ & & & MHC-SD-EN-T1-052, & \\
\hline 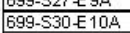 & 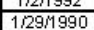 & $a$ & slug & 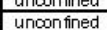 & single & Ringold & 1.157 & Boumer and Riose & & & & 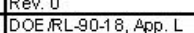 & \\
\hline 699-S30-E10A & $1 / 29 / 1990$ & $\mathrm{~b}$ & sug & unoonfined & single & Ringold & 1.157 & Boumer and Rice & & & & DOE RL $-90-18, A D P . L$ & \\
\hline 699-S30-E108 & $22 / 21990$ & a & slug & unoonfined & single & Hantord/Ringold & 1.157 & Boumer and Rios & & & & DOE RL- $90-18, \beta P P . L$ & \\
\hline 699-530-E10B & $212 / 990$ & $\mathrm{~b}$ & sug & unconfined & single & HanfordRingold & 1.157 & Boumer and Rice & & & & DOE RL-90-18, APP. L & \\
\hline 699-S31-E8A & $1 / 22 / 1990$ & a & sug & unoonfined & single & HanfordRingold & 0.457 & Eoumer and Rice & & & & DOE RL-90-18,APP. L & \\
\hline 699-S31-E8A & $1 / 22 / 1990$ & $\mathrm{~b}$ & $\frac{\text { sug }}{1+10}$ & unoonfined & single & $\begin{array}{l}\text { Hanford/Ringold } \\
\text { Bipald/2. }\end{array}$ & 0.457 & Eoumer and Rice & & & & DOE RL-90-18, App.L & \\
\hline$\frac{6999-5311-10 \mathrm{~A}}{6910 \mathrm{~A}}$ & \begin{tabular}{|l}
$21441 / 1900$ \\
$214 / 1990$ \\
\end{tabular} & $\frac{a}{b}$ & $\frac{\text { sug }}{\text { sug }}$ & $\begin{array}{l}\text { uncosfined } \\
\text { uncon fined }\end{array}$ & $\frac{\frac{s i n g l e}{\text { single }}}{\text { sing }}$ & $\frac{\text { Ringold }}{\text { Ringold }}$ & $\begin{array}{l}1.157 \\
1.157\end{array}$ & \begin{tabular}{|l} 
Boumer and Rice \\
Boumer and Rice
\end{tabular} & & & & 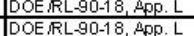 & \\
\hline 699-531-E10C & 1094990 & & sul & unomofned & single & Bingold & 1.157 & Foymer and Ripe & & & & DOE RI - $90-18 \triangle A O C$ & \\
\hline 699-S31-E10D & (1) & a & soges & 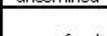 & single & & 1.157 & & & & & & \\
\hline 699-S31-E10D & $1 / 24 / 19900$ & $\mathrm{~b}$ & slug & unoonfined & single & Ringold & 1.157 & Eoumer and Rices & & & & DOE $\mathbb{R} L-90-18, A_{\mathrm{ppp}} \mathrm{L}$ & \\
\hline & $1 / 24 / 1990$ & & sug & unoonfined & & Ringold & & Eoumer and Rioe & & & & DOE RL-90-18, App.L & \\
\hline$\frac{699-532-E 8}{699-534-10}$ & $\frac{24211990}{281990}$ & $a$ & $\frac{\text { sug }}{\text { sug }}$ & $\begin{array}{l}\text { unoos fined } \\
\text { unconfined }\end{array}$ & $\frac{\frac{s}{\text { single }}}{\text { single }}$ & $\begin{array}{l}\text { Ringold } \\
\text { Hanford Ringold }\end{array}$ & $\begin{array}{l}1.157 \\
1.157\end{array}$ & $\begin{array}{l}\text { Boumer and Rioe } \\
\text { Boumer and Rioe }\end{array}$ & & & & 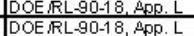 & \\
\hline 699-S34-E10 & $288 / 1990$ & $\mathrm{~b}$ & slug & unoonfined & single & Hanford Ringold & 1.157 & Boumer and Rice & & & & DOE RL-90-18, App. L & \\
\hline 699-S37-E11 & $2 / 2 / 1990$ & a & sug & unoonfined & single & Hanford & 1.157 & Boumer and Rios & & & & DOE $R L-90-18, A p p . L$ & \\
\hline 699-S37-E11 & $2 / 2 / 1990$ & $\mathrm{~b}$ & slug & unoonfined & single & Hanford & 1.157 & Boumer and Rice & & & & DOE RL-90-18, $A \mathrm{pp} . \mathrm{L}$ & \\
\hline 699-S38-E11 & $2 / 2 / 1990$ & $\mathrm{c}$ & slug & unconfined & single & Hanford & 1.157 & Boumer and Rices & & & & DOE RL-90-18, App. L & \\
\hline 699-S38-E12A & $2 \pi M 990$ & & sug & unoonfined & single & Ringold & 1.157 & Eoumer and Rice & & & & DOE RL-90-18, App. L & \\
\hline 699-S38-E12B & $2 \pi / 1990$ & 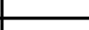 & sug & unoonfined & single & Ringold & 1.157 & Eoumer and Rios & & & & DOE RL-90-18, App $\mathrm{L}$ & \\
\hline$\frac{6999-541-11 \text { A }}{699-541-E 12}$ & \begin{tabular}{|l}
$21 / 19990$ \\
2128990 \\
\end{tabular} & $a$ & $\frac{s_{\text {sug }}}{\text { slug }}$ & $\begin{array}{l}\text { uncosfined } \\
\text { uncon fined }\end{array}$ & $\frac{\text { single }}{\text { single }}$ & $\begin{array}{l}\text { Hantord Ringold } \\
\text { Hantord Ringold }\end{array}$ & $\begin{array}{l}1.157 \\
1.157\end{array}$ & 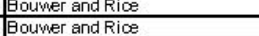 & & & & 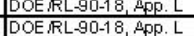 & \\
\hline 699-541_E12 & 21281990 & $b$ & sug & unoonfined & single & Hantord/Ringold & 1.157 & Boumer and Rice & & & & DOE $R \mathrm{RL}-90-18, \mathrm{APP}_{\mathrm{P}} \mathrm{L}$ & \\
\hline
\end{tabular}




\begin{tabular}{|c|c|c|c|c|c|c|c|c|c|c|c|c|c|}
\hline nell name & $\begin{array}{c}\text { test sart } \\
\text { date }\end{array}$ & sequence & $\begin{array}{c}\text { test type } \\
\text { (oonstart } \\
\text { rateistepisisug) }\end{array}$ & $\begin{array}{c}\text { aquifer type } \\
\text { (unconfined, } \\
\text { confined) } \\
\end{array}$ & $\begin{array}{l}\text { single or } \\
\text { multiple we } \\
\text { (single or } \\
\text { multiple) * }\end{array}$ & hydrogeologic unit tested & $\begin{array}{c}\text { maximum head } \\
\text { change at stress } \\
\text { well [m] }\end{array}$ & analysis method & $\begin{array}{l}\text { barometric } \\
\text { effects } \\
\text { rem oved } \\
\text { (yes or no) }\end{array}$ & \begin{tabular}{|c|}
$\begin{array}{c}\text { analysis } \\
\text { date }\end{array}$ \\
date
\end{tabular} & qually flag & reference / source & data location \\
\hline 699-S41 E13C & $28 / 1990$ & & sug & & single & Ringold & & Boumer and Rioe & & & & DOE RL-90-18,App . L & \\
\hline $699-17-47$ & $6 / 231969$ & & constant rate & & single & & 0.3 & $\begin{array}{l}\text { Cooper and Jaoob (1946) semilog } \\
\text { straightline }\end{array}$ & no & & & PNL-8337 & \\
\hline 699-40-39 & $8 / 44989$ & & $\frac{\text { sug }}{\text { sug }}$ & & $\begin{array}{l}\text { single } \\
\text { single }\end{array}$ & 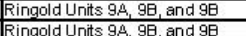 & 0.351 & \begin{tabular}{|l|l|} 
Cooper et al. Type-Curve \\
Cooper te al Thye-Curve
\end{tabular} & & & & PNL-7180 & $\begin{array}{l}\text { PNL-7180 } \\
\text { PNL-7180 }\end{array}$ \\
\hline $\begin{array}{ll}699-4-4-240 \\
699-42-42 \theta \\
\end{array}$ & $\frac{72 / 3699}{5 / 261993}$ & a & $\frac{\operatorname{sug}}{\text { sug }}$ & & $\begin{array}{l}\text { Singie } \\
\text { muttiple }\end{array}$ & & $\begin{array}{l}0.551 \\
8.86 \\
\end{array}$ & 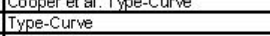 & & & & PNL-1080 & \\
\hline $699-42-428$ & $52: 261993$ & $\mathrm{~b}$ & sug & & muttiple & & 8.86 & Boumer and Rioe & & & & PNL-10835 & \\
\hline $\begin{array}{ll}699-42-42 \theta \\
69-934-41 E\end{array}$ & 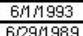 & & constant rate & & $\begin{array}{ll}\text { mutiples } \\
\text { singor }\end{array}$ & 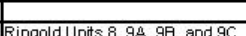 & 0351 & Type-Curve & no & & & $\begin{array}{ll}\mathrm{PNL}-10835 \\
\mathrm{PN}-7180\end{array}$ & 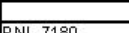 \\
\hline 699-43-41E & & & & & single & Ringold Units $8,9 \mathrm{~A}$, $9 \mathrm{~B}$, and $9 \mathrm{C}$ & 0.351 & Cooper et al. Type-Curve & & & & & PNL-7180 \\
\hline 699-43-41F & 5301989 & & sug & & single & Ringold Units $8,9 \mathrm{~A}, 9 \mathrm{~B}$, and $9 \mathrm{C}$ & 0.351 & Cooper et al. Type-Curve & & & & PNL-7180 & PNL-7180 \\
\hline 699-43-44 & $1,282,2000$ & a & stug & & single & & 1.117 & Boumer and Rios & & & & PNNL-13514 & $\begin{array}{l}\text { Sigma V, Room } \\
2606\end{array}$ \\
\hline 699-43-44 & $1 / 282,2000$ & $\mathrm{~b}$ & sug & & single & & 1.117 & Type-Curve & & & & PNNL-13514 & Sigma V, Room \\
\hline 699-43-44 & $4 \pi / 2000$ & & constant rate & & single & & & Type-Curve & yes & & & PNNL-13514 & Sigma V, Room \\
\hline 699-44-43B & $5 / 9 / 989$ & a & sug & uncon fined & single & $\begin{array}{l}\text { Han ford fomm ation Unit } 1 \text { and } \\
\text { Ringold Unit } 99\end{array}$ & 0.34 & Boumer and Rice & & & & $\begin{array}{l}\text { PNL-7180 } \\
\text { PN }\end{array}$ & PNL-7180 \\
\hline 699-44-438 & $5 / 91989$ & $\bar{b}$ & sing & unornfined & single & $\begin{array}{l}\text { Hantord form ation Unit } 1 \text { and } \\
\text { Ringold Unit } 9\end{array}$ & 0.34 & Boumer and Rice & & & & PNL-7180 & PNL-7180 \\
\hline 699-44-438 & $5 / 9 / 989$ & $\mathrm{c}$ & sing & unoon fined & single & $\begin{array}{l}\text { Hanford fom ation Unit } 1 \text { and } \\
\text { Ringold Unit } 9\end{array}$ & 0.34 & Cooper et al. Type-Curve & & & & PNL-7180 & PNL-7180 \\
\hline 699-44-43B & 5/9/9/989 & d & sug & unmotined & single & Han ford form ation Unit 1 and & 0.34 & Cooper et al. Type-Curve & & & & PNL-7180 & PNL-7180 \\
\hline 699-44-43B & 7154989 & a & stug & unonifned & single & 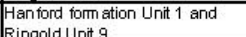 & 0.351 & Boumer and Rios & & & & PNL-7180 & PNL-7180 \\
\hline $\begin{array}{ll}699-44-438 \\
\end{array}$ & $7 / 5 / 989$ & $\bar{b}$ & siug & unconfined & single & $\begin{array}{l}\text { Hantford formation Unit } 1 \text { and } \\
\text { Ringold Unit } 9\end{array}$ & 0.351 & Cooper et al. Type-Curve & & & & $\begin{array}{l}\text { PNL-7180 } \\
\end{array}$ & PNL-7180 \\
\hline 699-77-54 & $7 / 234957$ & & constant rate & & single & & & $\begin{array}{c}\text { Cooper and Jacos (1946) sem ilog } \\
\text { straghtine }\end{array}$ & & & & PNL-8057 & \\
\hline 699-87-55 & $7 / 2 / 9699$ & & constant rate & & single & & & $\begin{array}{l}\text { Cooper and Jacob (1946) semilog } \\
\text { sraightline }\end{array}$ & & & & PNL-8057 & \\
\hline
\end{tabular}




\begin{tabular}{|c|c|c|c|c|c|c|c|c|c|c|}
\hline mell name & $\begin{array}{c}\text { test start } \\
\text { date }\end{array}$ & sequence & $\begin{array}{c}\text { static depth } \\
\text { to water at } \\
\text { time of test, } \\
\text { belowwref } \\
\text { point [m] }\end{array}$ & \begin{tabular}{|c|c|}
$\begin{array}{c}\text { reference } \\
\text { point } \\
\text { elevation } \\
\text { Im] }\end{array}$ \\
\end{tabular} & $\begin{array}{l}\text { reference datum } \\
\text { (ground surface, } \\
\text { top of casing, } \\
\text { brass cap, etc.) }\end{array}$ & $\begin{array}{c}\text { stress well open } \\
\text { interval, top } \\
\text { depth belowref } \\
\text { point [m] } \\
\end{array}$ & $\begin{array}{c}\text { sress well open } \\
\text { interval, bottom } \\
\text { depth belowret } \\
\text { point [m] }\end{array}$ & \begin{tabular}{|c}
$\begin{array}{c}\text { peroent of } \\
\text { aquiter } \\
\text { penetration } \\
\text { stress mell } \\
\text { (or } \\
\text { unknown) }\end{array}$ \\
\end{tabular} & \begin{tabular}{|c|c|} 
saturated \\
open \\
interval \\
length Im \\
\end{tabular} & Lomments \\
\hline$\frac{199-N-32}{299-E 18-1}$ & $\begin{array}{ll}3 / 26 / 984 \\
8 / 3 / 988\end{array}$ & a & 96.0 & 220.6 & $\begin{array}{l}\text { Top of } 6^{n} \\
\text { P rotedive Casing }\end{array}$ & 95.2 & 101.4 & partial & 5.4 & $\begin{array}{l}\text { Nor response in observation mell } \\
\text { Dramdown data analyzed }\end{array}$ \\
\hline 299-E18-1 & $8 / 3 / 988$ & $\mathrm{~b}$ & 96.0 & 220.6 & $\begin{array}{l}\text { Top of } 6^{\prime \prime} \\
\text { P rotedive Casing }\end{array}$ & 95.2 & 101.4 & & 5.4 & Drandown data analyzed \\
\hline 299-E18-1 & $8 / 3 / 1988$ & $\mathrm{c}$ & 96.0 & 220.6 & $\begin{array}{l}\text { Top of } 6^{\prime \prime} \\
\text { Protedive casing }\end{array}$ & 95.2 & 101.4 & & 5.4 & Recovery data analyzed \\
\hline $299-E 18-2$ & $11 / 4 / 988$ & & 96.3 & 220.9 & $\begin{array}{l}\text { Top of } 6^{\prime \prime} \\
\text { P rotedive Casing }\end{array}$ & 95.1 & 101.4 & & $?$ & $\begin{array}{l}\text { Dramdown data analyzed; no recovery data; (a) static } \\
\text { water level measured belowsilling well }\end{array}$ \\
\hline 299-E18-3 & $8 M 2 M 988$ & a & 96.5 & 221.2 & $\begin{array}{l}\text { Top of } 6^{\prime \prime} \\
\text { P rotedive Casing }\end{array}$ & 95.4 & 101.6 & & 5.2 & Drandown data analyzed \\
\hline $299-\mathrm{E} 18-3$ & $8 / 2 / 988$ & $\mathrm{~b}$ & 96.5 & 221.2 & $\begin{array}{l}\text { Top of } 6^{\prime \prime} \\
\text { Protedive Casing }\end{array}$ & 95.4 & 101.6 & & 5.2 & Recovery data analyzed \\
\hline $299-E 24-19$ & $10 / 2 / 989$ & & 87.3 & 211.9 & Top of 4" Casing & 85.5 & 91.9 & & 4.7 & Slug withdramal data analyzed \\
\hline $299-E 25-40$ & 9/29/1989 & & 78.7 & 203.5 & Top of 4" Casing & 77.2 & 83.6 & & 4.9 & Slug withdrawal data analyzed \\
\hline $299-E 25-41$ & 9/29/1989 & & 79.9 & & Ground surface & 77.8 & 84.2 & & 4.3 & Slug withdramal data provide best estimates \\
\hline $299-E 26-9$ & $8 / 13 / 990$ & & 60.0 & & $\begin{array}{l}\text { Top oftemporary } \\
12 " \text { casing }\end{array}$ & 58.7 & 61.9 & & 1.9 & $\begin{array}{l}\text { Partial submergenoe of sugging rod; Top of } \\
\text { temporary } 12 \text { casing is } 0.68 \mathrm{~m} \text { above ground surface }\end{array}$ \\
\hline 299-E26-11 & $8 / 28 / 990$ & & 58.6 & & \begin{tabular}{|l|} 
Top of temporary \\
$12 "$ casing
\end{tabular} & 61.8 & 63.5 & & 1.7 & $\begin{array}{l}\text { Top oftemporary } 12^{2} \text { casing is } 0.73 \mathrm{~m} \text { above ground } \\
\text { surface; Test interval may be under confined } \\
\text { conditions }\end{array}$ \\
\hline $299-E 27-8$ & $8 / 19 / 987$ & & 70.8 & & $\begin{array}{l}\text { Top of } \\
\text { Temporary 8" } \\
\text { Carbon Steel } \\
\text { Casing } \\
\end{array}$ & 76.2 & 79.3 & & 3.1 & $\begin{array}{l}\text { Test conducted in tem porary telescoping screen; } \\
\text { Dravdown data analyzed; Top of } 8 \text { "casing is } 0.98 \mathrm{~m} \\
\text { above ground surface }\end{array}$ \\
\hline $299-E 27-9$ & $8 / 15 / 1987$ & & 68.4 & & $?$ & 71.1 & 74.5 & & 3.3 & $\begin{array}{l}\text { Test conduded in tem porary telescoping screen; } \\
\text { Recovery data analyzed; Re ferenoe point datum } \\
\text { unknown }\end{array}$ \\
\hline 299-E27-10 & $8 / 1 / 1987$ & & 66.6 & & Top of silling well & 70.6 & 73.9 & & 3.3 & $\begin{array}{l}\text { Test conducted in tem porary telescoping screen; Top } \\
\text { of stilling well is } 0.73 \mathrm{~m} \text { above ground surface }\end{array}$ \\
\hline $299-E 27-13$ & $10 / 20 / 1989$ & & 80.0 & 204.6 & Top of 4" Casing & 77.9 & 84.3 & & 4.3 & Slug withdramal test $\$ 2$ provided best estimate \\
\hline $299-E 27-14$ & $10 / 20 / 1989$ & & 76.3 & 201.3 & Top of 4" Casing & 75.1 & 81.5 & & 5.2 & Slug withdrawal test $\# 3$ provided best estimate \\
\hline $299-E 27-15$ & $10 / 19 / 1989$ & & 75.6 & 200.0 & $\begin{array}{l}\text { Top of } 6^{\prime \prime} \\
\text { Protedive Casing }\end{array}$ & 73.4 & 79.8 & & 4.2 & Slug withdramal te $\$$ \#1 provided best estimate \\
\hline $299-E 28-27$ & 9/29/987 & & 83.9 & & Top of stilling well & 89.5 & 92.6 & & 3.1 & $\begin{array}{l}\text { Test conduced in tem porary telescoping screen; Top } \\
\text { of stilling well is } 0.73 \mathrm{~m} \text { above ground surface }\end{array}$ \\
\hline $299-E 324$ & 9/21/1987 & & 85.8 & & Top of silling well & 92.0 & 95.1 & & 3.1 & $\begin{array}{l}\text { Test conducted in tem porary telescoping screen; Top } \\
\text { of stilling well is } 1.15 \mathrm{~m} \text { above ground surface }\end{array}$ \\
\hline $299-E 32-5$ & $8 / 139990$ & & 84.6 & 209.0 & $\begin{array}{l}\text { Top of } 6^{\prime \prime} \\
\text { P rotedive Casing }\end{array}$ & 83.5 & 89.9 & & 5.3 & Average of tests $\# 1$ and $\# 2$ \\
\hline 299-E33-28 & $10 / 21 / 1987$ & & 79.3 & & Top of stilling mell & 82.6 & 85.7 & & 3.1 & $\begin{array}{l}\text { Test conducted in tem porary telescoping screen; Top } \\
\text { of stilling well is } 0.89 \mathrm{~m} \text { above ground surface }\end{array}$ \\
\hline $299-E 33-29$ & 9/17/987 & & 81.9 & & Top of stilling mell & 86.1 & 89.1 & & 3.1 & $\begin{array}{l}\text { Test conducted in tem porary telescoping screen; Top } \\
\text { of stilling well is } 0.87 \mathrm{~m} \text { above ground surface }\end{array}$ \\
\hline $299-E 33-30$ & 9/24/1987 & & 79.1 & & Top of stilling well & 82.1 & 85.2 & & 3.1 & $\begin{array}{l}\text { Test conduded in tem porary telescoping screen; Top } \\
\text { of stilling well is } 0.81 \mathrm{~m} \text { above ground surface }\end{array}$ \\
\hline $299-E 33-33$ & 9/27/1989 & & 71.8 & 196.2 & $\begin{array}{l}\text { Top of } 6^{\prime \prime} \\
\text { Protedive Casing }\end{array}$ & 70.2 & 76.6 & & 4.8 & Slug withdrawal te $\$$ \#2 provided best estimate \\
\hline $299-E 33-44$ & $10 / 13 / 1998$ & $\mathrm{a}$ & 72.5 & 196.0 & Erass cap & 72.5 & 77.1 & & 2.2 & \\
\hline $299-E 33-44$ & $10 / 13 / 1998$ & $b$ & 72.5 & 196.0 & Erass cap & 72.5 & 77.1 & & 2.2 & \\
\hline $299-E 33-334$ & $2 / 12000$ & $a$ & 80.5 & 203.3 & Erass cap & 78.6 & 86.2 & & 5.6 & \\
\hline $299-E 33-334$ & $2 M 12000$ & b & 80.5 & 203.3 & Brass cap & 78.6 & 86.2 & & 5.6 & \\
\hline $299-E 33-335$ & $3 / 28 / 2000$ & a & 80.7 & 203.4 & Erass cap & 79.3 & 85.4 & & 4.7 & \\
\hline 299-E33-335 & $3 / 28 / 2000$ & $\mathrm{~b}$ & 80.7 & 203.4 & Erass cap & 79.3 & 85.4 & & 4.7 & \\
\hline $299-E 34-2$ & $8 \pi / 1987$ & a & 69.1 & & Top of stilling well & 70.9 & 74.1 & & 3.1 & $\begin{array}{l}\text { Test conducted in tem porary telescoping screen; Top } \\
\text { of stilling well is } 0.81 \mathrm{~m} \text { above ground surface }\end{array}$ \\
\hline $299-E 34-2$ & $87 / 1987$ & b & 69.1 & & Top of stilling well & 70.9 & 74.1 & & 3.1 & $\begin{array}{l}\text { Test conducted in tem porary telescoping screen; Top } \\
\text { of stilling well is } 0.81 \mathrm{~m} \text { above ground surface }\end{array}$ \\
\hline $299-E 34-3$ & $8 / 5 / 1987$ & a & 62.6 & & Top of stilling well & 62.7 & 65.9 & & 3.1 & $\begin{array}{l}\text { Test conduded in tem porary telescoping screen; Top } \\
\text { of stilling well is } 0.69 \mathrm{~m} \text { above ground surface }\end{array}$ \\
\hline $299-E 34-3$ & $8 / 5 / 1987$ & $\bar{b}$ & 62.6 & & Top of stilling mell & 62.7 & 65.9 & & 3.1 & $\begin{array}{l}\text { Test conducted in tem porary telescoping screen; Top } \\
\text { of stilling well is } 0.69 \mathrm{~m} \text { above ground surface }\end{array}$ \\
\hline
\end{tabular}

Table A.2 Stress Well Depth Interval and Comments 


\begin{tabular}{|c|c|c|c|c|c|c|c|c|c|c|}
\hline 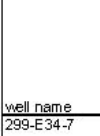 & \begin{tabular}{|c|}
$\begin{array}{c}\text { test start } \\
\text { date }\end{array}$ \\
$10 / 5 / 1989$
\end{tabular} & sequence & \begin{tabular}{|} 
static depth \\
to mater at \\
time of test. \\
belowref \\
point Iml \\
59.9 \\
\end{tabular} & $\begin{array}{c}\begin{array}{c}\text { reference } \\
\text { point } \\
\text { elevation } \\
\text { [m] }\end{array} \\
183.7\end{array}$ & $\begin{array}{l}\text { reference datum } \\
\text { (ground surface, } \\
\text { top of casing, } \\
\text { brass cap etc.) } \\
\text { Top of } 4^{\prime \prime ~ C a s i n g ~}\end{array}$ & \begin{tabular}{|c}
$\begin{array}{c}\text { stress well open } \\
\text { interval, top } \\
\text { depth belowret } \\
\text { point [m] }\end{array}$ \\
59.6
\end{tabular} & \begin{tabular}{|c|}
$\begin{array}{c}\text { stess well open } \\
\text { interval, bottom } \\
\text { depth belowref } \\
\text { point [m] }\end{array}$ \\
62.8 \\
\end{tabular} & 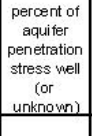 & $\begin{array}{c}\begin{array}{c}\text { saturated } \\
\text { open } \\
\text { interval } \\
\text { length Im] }\end{array} \\
2.9\end{array}$ & comments \\
\hline 299-E35-2 & $8 / 3 / 1990$ & & 59.7 & & \begin{tabular}{|l|} 
Top of temporary \\
12 c casing
\end{tabular} & 58.8 & 62.1 & & 2.4 & $\begin{array}{l}\text { Top of temporary } 12^{\prime \prime} \text { casing is } 0.63 \mathrm{~m} \text { above ground } \\
\text { surtace }\end{array}$ \\
\hline $299-W 6-2$ & 11/5/1987 & & 70.1 & & Top of stilling well & 73.2 & 76.3 & & 3.1 & $\begin{array}{l}\text { Test conduced in tem porary telescoping screen; Top } \\
\text { of stilling well is } 0.68 \mathrm{~m} \text { above ground surface }\end{array}$ \\
\hline $299-M^{2}-2$ & $11 / 5 / 987$ & & 70.1 & & Top of stilling well & 73.2 & 76.3 & & 3.1 & $\begin{array}{l}\text { Test conduced in tem porary telescoping screen; Top } \\
\text { of stilling well is } 0.68 \mathrm{~m} \text { above ground surface }\end{array}$ \\
\hline $299-W 7-1$ & $7 / 1 / 1987$ & a & 69.6 & & Top of stilling well & 71.9 & 74.9 & & 3.1 & $\begin{array}{l}\text { Test conducted in tem porary telescoping screen; Top } \\
\text { of stilling well is } 0.87 \mathrm{~m} \text { above ground surface }\end{array}$ \\
\hline $299-W 7-1$ & $7 / 15 / 987$ & $\mathrm{~b}$ & 69.6 & & Top of stilling well & 71.9 & 74.9 & & 3.1 & $\begin{array}{l}\text { Test conducted in tem porary telescoping screen; Top } \\
\text { of stilling well is } 0.87 \mathrm{~m} \text { above ground surface }\end{array}$ \\
\hline $299-W 7-2$ & 9/16/987 & a & 65.4 & & Top of stilling well & 65.4 & 68.5 & & 3.1 & $\begin{array}{l}\text { Test conduced in tem porary telescoping screen; Top } \\
\text { of stilling well is } 0.78 \mathrm{~m} \text { above ground surface }\end{array}$ \\
\hline $299-W 7-2$ & $9 / 16 / 1987$ & $\mathrm{~b}$ & 65.4 & & Top of stilling well & 65.4 & 68.5 & & 3.1 & $\begin{array}{l}\text { Test conduded in tem porary telescoping screen; Top } \\
\text { of stilling well is } 0.78 \mathrm{~m} \text { above ground surface }\end{array}$ \\
\hline 299-W7 4 & $11 / 12 / 1987$ & a & 63.6 & & Top of stilling well & 69.0 & 72.1 & & 3.1 & $\begin{array}{l}\text { Test conducted in tem porary telescoping screen; Top } \\
\text { of stilling well is } 1.06 \mathrm{~m} \text { above ground surface }\end{array}$ \\
\hline $299-W 7-4$ & $11 / 12 / 1987$ & $\mathrm{~b}$ & 63.6 & & Top of stilling well & 69.0 & 72.1 & & 3.1 & $\begin{array}{l}\text { Test conducted in tem porary telescoping screen; Top } \\
\text { of stilling well is } 1.06 \mathrm{~m} \text { above ground surface }\end{array}$ \\
\hline 299-W7-5 & $11 / 21 / 1987$ & & 63.9 & 206.2 & Top of 4" Casing & 64.1 & 70.2 & & 6.1 & $\begin{array}{l}\text { Test conducted in final well screen; Recovery data } \\
\text { incomplete }\end{array}$ \\
\hline $299-W 7-6$ & $10 / 14 / 1987$ & a & 66.7 & & Top of stilling well & 71.5 & 74.6 & & 3.1 & $\begin{array}{l}\text { Test conducted in tem porary telescoping screen; Top } \\
\text { of stilling well is } 1.09 \mathrm{~m} \text { above ground surface }\end{array}$ \\
\hline $299-W 7-6$ & $10 / 14 / 1987$ & $\mathrm{~b}$ & 66.7 & & Top of stilling mell & 71.5 & 74.6 & & 3.1 & $\begin{array}{l}\text { Test conducted in tem porary telescoping screen; Top } \\
\text { of stilling well is } 1.09 \mathrm{~m} \text { above ground surface }\end{array}$ \\
\hline $299-W 7-7$ & $12 / 5 / 1989$ & & 64.6 & 206.3 & Top of 4" Casing & 63.5 & 69.8 & & 5.2 & \\
\hline 299-W8-1 & $7 / 11 / 1987$ & & 72.8 & & Top of stilling well & 79.2 & 82.2 & & 3.1 & $\begin{array}{l}\text { Test conducted in tem porary telescoping screen; Top } \\
\text { of stilling well is } 0.83 \mathrm{~m} \text { above ground surface }\end{array}$ \\
\hline 299-W9-1 & $10 / 23 / 1987$ & a & 82.8 & 226.0 & Top of 4" Casing & 81.8 & 87.9 & & 5.1 & \\
\hline $299-\mathrm{WM}$ & $10 / 23 / 1987$ & $\mathrm{~b}$ & 82.8 & 226.0 & Top of 4" Casing & 81.8 & 87.9 & & 5.1 & \\
\hline $299-\mathrm{W}_{10-13}$ & $9 / 1 / 4 / 987$ & & 71.0 & & Top of stilling well & 70.6 & 76.7 & & 5.6 & $\begin{array}{l}\text { Test conduded in tem porary telescoping screen; Top } \\
\text { of stilling well is } 1.21 \mathrm{~m} \text { above ground surface; } \\
\text { observation well not completed }\end{array}$ \\
\hline 299-W1 0-14 & 10/26/1987 & & 71.3 & & Top of stilling well & 134.1 & 137.2 & & 3.1 & $\begin{array}{l}\text { Test conducted in tem porary telescoping screen; Top } \\
\text { of stilling well is } 0.94 \mathrm{~m} \text { above ground surface; no dat. } \\
\text { for observation well }\end{array}$ \\
\hline$\frac{299-\mathrm{M} M 0-15}{299-\mathrm{WM} 0-16}$ & 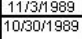 & & $\frac{62.8}{62.3}$ & 205.7 & \begin{tabular}{|l|} 
Ground surface \\
Top of 4" Casing
\end{tabular} & $\frac{61.3}{60.9}$ & $\frac{67.7}{67.3}$ & & $\frac{4.9}{5.0}$ & Slug withdramal test $\# 3$ provided best results \\
\hline 299-W10-17 & $1 / 115 / 999$ & $a$ & $\sim 62.5$ & & Ground surface & 61.4 & 67.9 & & & \\
\hline 299-W1 0-17 & $1 / 1559991$ & $b$ & -62.5 & & Ground surface & 61.4 & 67.9 & & $\frac{5.8}{5.8}$ & \\
\hline 299-W10-18 & 1,1961991 & & $\sim 61.6$ & & Ground surface & 60.9 & 67.4 & & 5.8 & \\
\hline 299-W10-23 & $18 / 1999$ & $a$ & 68.6 & 206.7 & Brass cap & 68.8 & 79.5 & \#REF! & 10.7 & \\
\hline $299-\mathrm{W} 10-23$ & $1,8 M 999$ & $\mathrm{~b}$ & 68.6 & 206.7 & Erass cap & 68.8 & 79.5 & $\begin{array}{l}\mathrm{ARE} \\
\mathrm{NRE}\end{array}$ & 10.7 & \\
\hline $299-W_{1} 0-24$ & $1 / 11$ M999 & $a$ & 71.0 & 209.0 & Brass cap & 71.0 & 81.7 & \#RE & 10.7 & \\
\hline 299-W $10-24$ & $1 / 111999$ & b & 71.0 & 209.0 & Erass cap & 71.0 & 81.7 & $\frac{H R E}{H R E}$ & 10.7 & \\
\hline $299-\mathrm{W}_{10-24}$ & $4 / 21 / 1999$ & & & 209.0 & Brass cap & 71.0 & 81.7 & \#REF! & 10.7 & \\
\hline $299-W_{1} 0-26$ & $10 / 45 / 1998$ & a & 66.2 & 204.7 & Brass cap & 66.2 & 76.9 & \#REF! & 10.4 & \\
\hline 299-W10-26 & $10 / 15 / 1998$ & $b$ & 66.2 & 204.7 & Brass cap & 66.2 & 76.9 & \#REF! & 10.4 & \\
\hline 299-W10-26 & $4 / 24 / 1999$ & & & 204.7 & Brass cap & 66.2 & 76.9 & \#REF! & 10.4 & \\
\hline 299-W1 4-13 & $10 / 44 / 1998$ & $a$ & 66.0 & 204.4 & Brass cap & 66.0 & 76.7 & \#REF! & 10.6 & \\
\hline 299-W1 4-13 & $10 / 44 / 1998$ & $\mathrm{~b}$ & 66.0 & 204.4 & Brass cap & 66.0 & 76.7 & \#REF! & 10.6 & \\
\hline $299-$ W1 4-13 $^{2}$ & $4 / 1 / 1999$ & & & 204.4 & Brass cap & 66.0 & 76.7 & \#REF! & 10.6 & \\
\hline 299-W/ 4-14 & 11111999 & a & 66.1 & 204.6 & Brass cap & 66.1 & 76.8 & \#REF! & 10.7 & \\
\hline $299-W / 44-14$ & 1 1M1M999 & $\mathrm{b}$ & 66.1 & 204.6 & Brass cap & 66.1 & 76.8 & \#REF! & 10.7 & \\
\hline 299-W15-15 & $8 / 21 / 1987$ & & 69.5 & & Top of stilling well & 75.4 & 78.4 & & 3.1 & $\begin{array}{l}\text { Test conducted in tem porary telescoping screen; Top } \\
\text { of stilling well is } 0.72 \mathrm{~m} \text { above ground surface }\end{array}$ \\
\hline 299-W15-16 & $8 / 20 / 1987$ & a & 65.2 & & Top of stilling well & 70.0 & 73.0 & & 3.1 & $\begin{array}{l}\text { Test conduced in tem porary telescoping screen; Top } \\
\text { of stilling well is } 0.63 \mathrm{~m} \text { above ground surface; } \\
\text { observation well data analyzed using Theis and } \\
\text { semilog methods }\end{array}$ \\
\hline $299-\mathrm{W} 15-16$ & $8: 20 / 1987$ & $\bar{b}$ & 65.2 & & Top of stilling well & 70.0 & 73.0 & & 3.1 & $\begin{array}{l}\text { Test conduced in tem porary telescoping screen; Top } \\
\text { of stilling well is } 0.63 \mathrm{~m} \text { above ground surface }\end{array}$ \\
\hline $299-W 15-18$ & $7 / 21 / 1987$ & & 65.5 & & Top of stilling well & 71.8 & 74.8 & & 3.1 & $\begin{array}{l}\text { Test conducted in tem porary telescoping screen; Top } \\
\text { of stling well above ground surface is } 0.98 \mathrm{~m} \text { above } \\
\text { ground surface }\end{array}$ \\
\hline 299-W/ 5-19 & $10 / 30 / 1989$ & & 67.3 & 211.4 & Top of 4" Casing & 65.6 & 72.5 & & 5.2 & Slug withdramal test provided best results \\
\hline
\end{tabular}




\begin{tabular}{|c|c|c|c|c|c|c|c|c|c|c|}
\hline mell name & \begin{tabular}{|c|}
$\begin{array}{c}\text { test start } \\
\text { date }\end{array}$ \\
113409
\end{tabular} & sequence & \begin{tabular}{|c} 
static depth \\
to water at \\
time of test \\
belowret \\
point [m] \\
\end{tabular} & $\begin{array}{c}\begin{array}{c}\text { reference } \\
\text { point } \\
\text { elevation } \\
{[m]}\end{array} \\
\end{array}$ & $\begin{array}{l}\text { reference datum } \\
\text { ground surface, } \\
\text { top of casing, } \\
\text { brass cap, etc.) }\end{array}$ & $\begin{array}{c}\text { stress mell open } \\
\text { interval, top } \\
\text { depth belowret } \\
\text { point iml } \\
\end{array}$ & $\begin{array}{c}\text { stress well open } \\
\text { interval, bottom } \\
\text { depth belowret } \\
\text { point [m] }\end{array}$ & $\begin{array}{c}\text { percent of } \\
\text { aquifer } \\
\text { penetration } \\
\text { stress nell } \\
\text { cor } \\
\text { unknown) }\end{array}$ & $\begin{array}{l}\text { saturated } \\
\text { open } \\
\text { interval } \\
\text { length [m] }\end{array}$ & oomments \\
\hline 299-W15-20 & 11/3/989 & a & \begin{tabular}{|l|}
69.9 \\
\end{tabular} & 214.0 & Top of 4" Casing & & & & & \\
\hline $299-\mathrm{W} 15-20$ & 11/3/4989 & $\mathrm{b}$ & 69.9 & 214.0 & Top of 4" Casing & 67.9 & 74.3 & & 4.5 & \\
\hline $299-W 15-22$ & 1/15/1991 & a & 61.9 & & Ground surface & 60.5 & 67.0 & & 5.2 & Incorrect analysis? \\
\hline$\frac{2939-W_{1}-25}{29-22}$ & 1/115/1991 & $\frac{a}{b}$ & 61.9 & & Ground surface & 60.5 & 67.0 & & 5.2 & \\
\hline $299-W M 15-24$ & $12 / 18 \% 1989$ & & $?$ & & $?$ & 67.1 & 73.5 & & $?$ & \\
\hline $299-W 1540$ & $10 / 4411998$ & a & 66.4 & 205.1 & Brass cap & 66.4 & 77.1 & \#REF! & 10.5 & \\
\hline $299-W 1540$ & $10 / 14 / 1998$ & $\frac{a}{b}$ & 66.4 & 205.1 & Erass cap & 66.4 & 77.1 & HREF! & 10.5 & \\
\hline $299-$ WM 541 & $3 / 29 / 2000$ & $\mathrm{a}$ & 65.6 & 202.8 & Brass cap & 65.8 & 70.4 & \#REF! & 4.6 & \\
\hline $299-\mathrm{W} 15-41$ & $3 / 29 / 2000$ & $b$ & 65.6 & 202.8 & Erass cap & 65.8 & 70.4 & \#REF! & 4.6 & \\
\hline 299-WM15-41 & $5 / 10 / 2000$ & & 65.4 & 202.8 & Erass cap & 65.8 & 70.4 & \#REF! & 4.6 & \\
\hline $299-\mathrm{MM18-21}$ & $7 / 1 / 4987$ & $\mathrm{a}$ & 60.5 & & Top of stilling well & 66.6 & 69.6 & & 3.1 & $\begin{array}{l}\text { Test conducted in tem porary telescoping screen; Top } \\
\text { of stilling well is } 0.88 \mathrm{~m} \text { above ground surface; } \\
\text { observation well not completed }\end{array}$ \\
\hline 299-W/8-21 & $7 / 4 / 1987$ & $\mathrm{~b}$ & 60.5 & & Top of stilling well & 66.6 & 69.6 & & 3.1 & $\begin{array}{l}\text { Test conduded in tem porary telescoping screen; Top } \\
\text { of stilling well is } 0.88 \mathrm{~m} \text { above ground surface; } \\
\text { observation well not completed }\end{array}$ \\
\hline $299-\mathrm{W} / 18-22$ & \begin{tabular}{|l|}
$8 / 26 / 1987$ \\
\end{tabular} & & 60.7 & & Top of stilling well & 134.0 & 137.1 & & 3.1 & $\begin{array}{l}\text { Test conduded in tem porary telescoping screen; Top } \\
\text { of stilling well is } 0.69 \mathrm{~m} \text { above ground surface }\end{array}$ \\
\hline $299-\mathrm{W} / 8-23$ & $6 / 22 / 987$ & a & 68.9 & & Top of stilling well & 73.9 & 77.0 & & 3.1 & $\begin{array}{l}\text { Test conducted in tem porary telescoping screen; Top } \\
\text { of stilling well is } 0.46 \mathrm{~m} \text { above ground surface }\end{array}$ \\
\hline $299-W_{1} 18-23$ & 6/22/1987 & $\mathrm{b}$ & 68.9 & & Top of stilling well & 73.9 & 77.0 & & 3.1 & $\begin{array}{l}\text { Test conducted in tem porary telescoping screer; Top } \\
\text { of stilling well is } 0.46 \mathrm{~m} \text { above ground surface }\end{array}$ \\
\hline 299-WM18-24 & 7/17/987 & & 65.1 & & Top of stilling well & 71.1 & 74.2 & & 3.1 & $\begin{array}{l}\text { Test conduded in tem porary telescoping screen; Top } \\
\text { of stilling well is } 1.0 \mathrm{~m} \text { above ground surface; } \\
\text { observation well data analyzed by Theis recovery } \\
\text { method }\end{array}$ \\
\hline $299-\mathrm{W} 18-25$ & $\frac{12 / 2 / 1990}{12421990}$ & $a$ & 59.1 & & Ground surface & 59.0 & 65.5 & & 6.4 & \\
\hline $299-$ W1 8-25 & $12 / 12 / 1990$ & $\mathrm{~b}$ & 59.1 & & Ground surface & 59.0 & 65.5 & & 6.4 & \\
\hline $299-$ W18-26 & $11 / 22 / 1989$ & & 69.4 & & Top of 4" Casing & 68.1 & 74.5 & & 5.1 & \\
\hline 299-W19-31 & 1/1779991 & $a$ & 62.7 & & Ground surface & 61.4 & 67.9 & & 5.2 & \\
\hline$\frac{299-2 \times 19-31}{20194020}$ & $1 / 17 / 1991$ & $b$ & 62.7 & & Ground surface & 61.4 & 67.9 & & 5.2 & \\
\hline $299-W_{1} 19-32$ & $1 / 1441991$ & a & 62.7 & & Ground surface & 61.5 & 67.8 & & 5.1 & \\
\hline $299-W_{19-32}$ & 1/M4/1991 & $\mathrm{b}$ & 62.7 & & Ground surface & 61.5 & 67.8 & & 5.1 & \\
\hline 299-W19-41 & $10 / 19 ; 1998$ & a & 67.1 & 205.8 & Erass cap & 67.1 & 77.8 & \#REF! & 10.3 & \\
\hline $299-W 1941$ & $10 / 19 / 1998$ & $\mathrm{~b}$ & 67.1 & 205.8 & Brass cap & 67.1 & 77.8 & \#REF! & 10.3 & \\
\hline $299-W_{19-42}$ & $10 / 15 / 1998$ & $a$ & 67.1 & 205.5 & Brass cap & 67.1 & 77.8 & \#REF! & 10.7 & \\
\hline $299-$ WM19-42 & $10 / 15 / 1998$ & $\mathrm{~b}$ & 67.1 & 205.5 & Brass cap & 67.1 & 77.8 & \#REF! & 10.7 & \\
\hline 299-WM1942 & $3 / 26 / 1999$ & & & 205.5 & Erass cap & 67.1 & 77.8 & \#REF! & 10.7 & \\
\hline$\frac{2939-1 / 32245}{299-W 245}$ & $1 / 27 / 2000$ & $a$ & 65.6 & 203.1 & Brass cap & 60.1 & $\frac{16.0}{71.3}$ & AREF! & $\frac{10.7}{5.7}$ & Heterogeneous, result for outer zone \\
\hline $299-W 2245$ & $1 / 27 / 2000$ & $\mathrm{~b}$ & 65.6 & 203.1 & Brass cap & 60.4 & 71.3 & AREF! & 5.7 & Heterogeneous, result for outer zone \\
\hline $299-W 2246$ & $4,1 / 1,2000$ & $\frac{a}{a}$ & 67.1 & 204.6 & Brass cap & 58.8 & 69.8 & HREF! & 2.7 & \\
\hline $299-W 22246$ & $\begin{array}{ll}4 / 1 / 322000 \\
4 / 2000 \\
\end{array}$ & $\frac{a}{b}$ & 67.1 & 204.6 & Brass cap & 58.8 & 69.8 & \#REF! & $\frac{2.1}{2.7}$ & \\
\hline $299-W 22-48$ & $1 / 26 / 2000$ & $a$ & 69.7 & 207.1 & Brass cap & 69.0 & 73.5 & \#REF! & 3.8 & \\
\hline $299-W 2248$ & $1 / 26 / 2000$ & $\mathrm{~b}$ & 69.7 & 207.1 & Brass cap & 69.0 & 73.5 & \#REF! & 3.8 & \\
\hline $299-W 22-48$ & $5 / 22 / 2000$ & & 69.8 & 207.1 & Brass cap & 69.0 & 73.5 & \#REF! & 3.7 & \\
\hline $299-W 22-49$ & $1 / 27 / 2000$ & $\mathrm{a}$ & 66.5 & 203.9 & Brass cap & 66.4 & 71.0 & \#REF! & 4.5 & \\
\hline $299-W / 22-49$ & $1 / 27 / 2000$ & b & 66.5 & 203.9 & Brass cap & 66.4 & 71.0 & \#REF! & 4.5 & \\
\hline $299-W 2249$ & $4 / 20 / 2000$ & & 66.5 & 203.9 & Brass cap & 66.4 & 71.0 & \#REF! & 4.5 & \\
\hline $299-W 22-50$ & $4 / 10 / 2000$ & $a$ & 66.7 & 204.1 & Brass cap & 66.4 & 71.0 & \#REF! & 4.3 & \\
\hline $299-W 2250$ & $4 / 10,2000$ & $\mathrm{~b}$ & 66.7 & 204.1 & Brass cap & 66.4 & 71.0 & AREF! & 4.3 & \\
\hline$\frac{299-W 22-50}{290}$ & $5 / 31 / 2000$ & & 66.7 & 204.1 & Brass cap & 66.4 & 71.0 & \#REF! & 4.3 & \\
\hline $299-W 22-79$ & $10 / 19 / 1998$ & $a$ & 74.0 & 210.9 & Brass cap & 74.0 & 84.7 & \#REF! & 10.7 & \\
\hline $299-W / 22-79$ & $10 / 9 / 1998$ & $\mathrm{~b}$ & 74.0 & 210.9 & Brass cap & 74.0 & 84.7 & \#REF! & 10.7 & \\
\hline $299-W 22-80$ & $10 / 25 / 2000$ & $a$ & & & Brass cap & & & & & \\
\hline $299-W 22-80$ & $10 / 25 / 2000$ & $\mathrm{~b}$ & & & Brass cap & & & & & \\
\hline $299-W 22-81$ & $4 / 30 / 2001$ & a & & & Erass cap & & & & & Heterogeneous, result for outer zone \\
\hline $299-W 22-81$ & $4 / 3022001$ & $\frac{a b}{b}$ & & & Erass cap & & & & & Heterogeneous, result for outer zone \\
\hline $299-W 22-82$ & $4,25 / 2001$ & a & & & Brass cap & & & & & Heterogeneous, result for outer zone \\
\hline $299-W 22-82$ & $4 / 25 / 2001$ & $\mathrm{~b}$ & & & Erass cap & & & & & Heterogeneous, result for outer zone \\
\hline $299-W 22-83$ & $4 / 26 / 2001$ & a & & & Brass cap & & & & & Heterogeneous, result for outer zone \\
\hline $299-W 22-83$ & $4 / 26 / 2001$ & $\mathrm{~b}$ & & & Erass cap & & & & & Heterogene ous, result for outer zone \\
\hline $299-W / 22-84$ & $12 / 4 / 2001$ & $a$ & & & Brass cap & & & & & Heterogeneous, result for outer zone \\
\hline $299-W / 22-84$ & $12 / 4 / 2001$ & $\mathrm{~b}$ & & & Erass cap & & & & & Heterogeneous, result for outer zone \\
\hline $299-W 22-85$ & $12 / 5 / 2001$ & $a$ & & & Brass cap & & & & & Heterogeneous, result for outer zone \\
\hline $299-W / 22-85$ & $12 / 5 / 2001$ & $\mathrm{~b}$ & & & Brass cap & & & & & Heterogeneous, result for outer zone \\
\hline $299-W 23-13$ & $12 / 12 / 1990$ & & 60.5 & & Ground surface & 59.7 & 66.2 & partial & 5.7 & \\
\hline 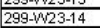 & $5 / 211991$ & a & 60.8 & & Ground surface & $\frac{59.1}{59.1}$ & 65.2 & $\frac{\text { pantian }}{\text { partial }}$ & $\frac{1.8}{4.8}$ & \\
\hline 299-W23-14 & $5 / 12 M 991$ & $\frac{a b}{b}$ & 60.8 & & Ground surfaoe & 59.1 & 65.6 & partial & 4.8 & \\
\hline $299-W / 23-15$ & $1 / 24 / 2000$ & a & 62.1 & 199.8 & & 56.6 & 67.8 & \#REF! & 5.7 & \\
\hline $299-W 23-15$ & $1 / 24 / 2000$ & $\mathrm{~b}$ & 62.1 & 199.8 & Brass cap & 56.6 & 67.8 & \#REF! & 5.7 & Heterogeneous, result for outer zone \\
\hline $299-W 23-20$ & $11 / 1 / 2000$ & $a$ & & & $s$ cap & & & & & \\
\hline $299-W 23-20$ & $11 / 1 / 2000$ & $\mathrm{~b}$ & & & Brass cap & & & & & \\
\hline $299-W 23-21$ & $1,30 / 2001$ & a & & & Erass cap & & & & & Heterogeneous, result for outer zone \\
\hline $299-W 23-21$ & $1,30 / 2001$ & $\mathrm{~b}$ & & & Brass cap & & & & & Heterogene ous, result for outer zone \\
\hline$\frac{2399-W 26-8}{299-8}$ & $5 / 31 / 1990$ & & $\sim 61$ & & Ground surface & 59.3 & 65.8 & partial & 5.1 & \\
\hline$\frac{293-\sqrt{2}-200}{299-9}$ & \begin{tabular}{|l|l|}
$5 / 3 / 9990$ \\
\end{tabular} & & -57.6 & & Ground surface & 56.3 & 62.5 & $\frac{\text { partitial }}{\text { partal }}$ & 4.9 & \\
\hline $299-W 26-10$ & $5 / 31 / 1990$ & & $\sim 63$ & & Ground surface & 61.3 & 67.5 & partial & 4.6 & \\
\hline $299-W 26-11$ & $5 / 31 / 1990$ & a & -37.2 & & Ground surface & 35.1 & 41.2 & partial & 5.1 & \\
\hline $299-W 26-11$ & $5 / 31 / 1990$ & $\mathrm{~b}$ & -37.2 & & Ground surface & 35.1 & 41.2 & partial & 5.1 & \\
\hline $299-W 26-12$ & $5 / 104990$ & a & $\sim 64.1$ & & Ground surface & 63.2 & 69.5 & partial & 5.5 & \\
\hline
\end{tabular}




\begin{tabular}{|c|c|c|c|c|c|c|c|c|c|c|}
\hline well name & $\begin{array}{c}\text { test start } \\
\text { date }\end{array}$ & sequence & $\begin{array}{c}\text { static depth } \\
\text { to water at } \\
\text { time of test } \\
\text { belowref } \\
\text { point [m] }\end{array}$ & $\begin{array}{c}\text { reference } \\
\text { point } \\
\text { elevation } \\
\text { [m] }\end{array}$ & $\begin{array}{l}\text { reference datum } \\
\text { (ground surface, } \\
\text { top of casing, } \\
\text { brass cap, etc.) }\end{array}$ & $\begin{array}{c}\text { stress well open } \\
\text { interval, top } \\
\text { depth belowref } \\
\text { point [m] }\end{array}$ & $\begin{array}{c}\text { stress well open } \\
\text { interval, bottom } \\
\text { depth belowref } \\
\text { point [m] }\end{array}$ & $\begin{array}{l}\text { percent of } \\
\text { aquifer } \\
\text { penetration } \\
\text { stress well } \\
\text { (or } \\
\text { unknown) } \\
\end{array}$ & $\begin{array}{l}\text { saturated } \\
\text { open } \\
\text { interval } \\
\text { length [m] }\end{array}$ & comments \\
\hline $299-W 26-12$ & 5 M10i1990 & b & \begin{tabular}{|c|c|}
$\sigma 64.1$ \\
\end{tabular} & & Ground surface & \begin{tabular}{|l|l|}
63.2 \\
6
\end{tabular} & \begin{tabular}{|l|l|}
69.5 \\
\end{tabular} & partial & 5.5 & \\
\hline $299-W 26-13$ & $1 / 25 / 2000$ & a & 61.6 & 199.0 & Brass cap & 61.6 & 72.3 & \#REF! & 10.7 & \\
\hline$\frac{2939-W / 26-13}{290-13}$ & 1,2522000 & $\frac{a}{b}$ & 61.6 & 199.0 & Brass cap & 61.6 & 72.3 & \#REF! & 10.7 & \\
\hline $399-1-9$ & $3 / 2 / 1987$ & & 3.3 & 117.8 & Brass cap & 51.8 & 54.9 & \#REF! & 3.1 & \\
\hline $399-1-10$ & $11 / 25 / 1986$ & a & 8.8 & 114.4 & Brass cap & 9.1 & 12.2 & partial & 3.1 & Test conducted in tem porary telescoping screen \\
\hline $399-1-10$ & $11 / 25 / 1986$ & $\mathrm{~b}$ & 8.8 & 114.4 & Brass cap & 9.1 & 12.2 & partial & 3.1 & Test conduced in tem porary telescoping screen \\
\hline $399-1-10$ & $11 / 25 / 1986$ & $\mathrm{c}$ & 8.8 & 114.4 & Brass cap & 9.1 & 12.2 & partial & 3.1 & Test conduded in tem porary telescoping screen \\
\hline $399-1-13$ & $11 / 5 / 986$ & a & 13.2 & 118.6 & Brass cap & 13.1 & 16.2 & partial & 3.0 & Test conducted in tem porary telescoping screen \\
\hline $399-1-13$ & $11 / 5 / 1986$ & $\mathrm{~b}$ & 13.2 & 118.6 & Brass cap & 13.1 & 16.2 & partial & 3.0 & Test conduded in tem porary telescoping screen \\
\hline $399-1-13$ & $11 / 5 / 1986$ & $\mathrm{c}$ & 13.2 & 118.6 & Brass cap & 13.1 & 16.2 & partial & 3.0 & Test conduded in tem porary telescoping screen \\
\hline $399-1-14$ & $11 / 12 / 1986$ & & $?$ & & Ground surface & 11.3 & 14.3 & partial & $?$ & $\begin{array}{l}\text { Test conduced in tem porary telescoping screen; } \\
\text { Distance between top of } 10^{\prime \prime} \text { casing and ground } \\
\text { surface is unknown }\end{array}$ \\
\hline $399-1-16 \mathrm{~A}$ & $2 / 26 / 987$ & a & 11.7 & 116.9 & Brass cap & 9.8 & 14.3 & \#REF! & 2.6 & Observation mell data affected by river stage \\
\hline $399-1-16 \mathrm{~A}$ & $2 / 26,998$ & $b$ & 11.7 & 116.9 & Brass cap & 9.8 & 14.3 & \#REF! & 2.6 & Observation well data affected by river stage \\
\hline $399-1-16 \mathrm{~A}$ & $2 / 26 / 987$ & $\mathrm{c}$ & 11.7 & 116.9 & Brass cap & 9.8 & 14.3 & \#REF! & 2.6 & observation well data affected by river stage \\
\hline $399-1-168$ & $2 / 9,987$ & a & 11.5 & 116.9 & Brass cap & 32.0 & 35.1 & \#REF! & 3.1 & Test \#1; Ob servation well data analyzed \\
\hline $399-1-160$ & $2 / 9 M 987$ & $\frac{a}{b}$ & 11.5 & 116.9 & Brass cap & $\frac{32.0}{32.0}$ & $\frac{3.1}{35.1}$ & \#REF! & $\frac{3.1}{3.1}$ & Test \#1; Observation well data analyzed \\
\hline $399-1-168$ & $2 / 24 / 1987$ & a & 11.4 & 116.9 & Brass cap & 32.0 & 35.1 & \#REF! & 3.1 & Test \#2; Observation well data analyzed \\
\hline $399-1-168$ & $2 / 24 / 1987$ & $\mathrm{~b}$ & 11.4 & 116.9 & Brass cap & 32.0 & 35.1 & \#REF! & 3.1 & Test \#2; Observation mell data analyzed \\
\hline $399-1-16 \mathrm{C}$ & $2 / 7 / 1987$ & a & 8.2 & 117.1 & Brass cap & 50.9 & 54.1 & \#REF! & 3.2 & \\
\hline $399-1-16 \mathrm{CC}$ & $2,1 / 79087$ & $\frac{a}{b}$ & 8.2 & 117.1 & Brass cap & 50.9 & 54.1 & \#REF! & 3.2 & \\
\hline $399-1-16 \mathrm{C}$ & $2 M 7 / M 987$ & $\mathrm{c}$ & 8.2 & 117.1 & Brass cap & 50.9 & 54.1 & \#REF! & 3.2 & \\
\hline $399-1-178$ & $2,9 / 1987$ & a & 10.2 & 115.5 & Brass cap & 30.5 & 33.5 & \#REF! & 3.1 & \\
\hline $399-1-178$ & $2 / 9 / 1987$ & b & 10.2 & 115.5 & Erass cap & 30.5 & 33.5 & \#REF! & 3.1 & \\
\hline $399-1-178$ & $2 / 9 / 4987$ & $\mathrm{c}$ & 10.2 & 115.5 & Brass cap & 30.5 & 33.5 & \#REF! & 3.1 & \\
\hline $399-1-17 \mathrm{C}$ & $2 / 1 / 988$ & $a$ & 0.2 & 115.5 & Brass cap & 49.1 & 52.1 & HREF! & 3.1 & \\
\hline $399-1-17 \mathrm{C}$ & $2 / 1 / 1987$ & $\mathrm{~b}$ & 0.2 & 115.5 & Brass cap & 49.1 & 52.1 & \#REF! & 3.1 & \\
\hline $399-1-17 \mathrm{C}$ & $2 M 1 / 1987$ & c & 0.2 & 115.5 & Erass cap & 49.1 & 52.1 & \#REF! & 3.1 & \\
\hline $399-1-18 \mathrm{~A}$ & $11 / 11 / 1986$ & a & 13.5 & 119.2 & Erass cap & 13.4 & 16.5 & \#REF! & 3.0 & \\
\hline $399-1-18 \mathrm{~A}$ & 11/11/1986 & b & 13.5 & 119.2 & Erass cap & 13.4 & 16.5 & \#REF! & 3.0 & \\
\hline $399-1-18 \mathrm{~B}$ & $1 / 29 / 1987$ & a & 12.8 & 119.1 & Brass cap & 33.2 & 36.3 & \#REF! & 3.1 & \\
\hline $399-1-180$ & $1 / 29 / 1987$ & b & 12.8 & 119.1 & Erass cap & 33.2 & 36.3 & \#REF! & 3.1 & \\
\hline $399-1-18 \mathrm{C}$ & $2 / 3 / 1987$ & $a$ & 12.6 & 118.5 & Brass cap & 39.6 & 42.7 & partial & 3.1 & \\
\hline $399-1-18 \mathrm{C}$ & $2 / 3 / 1987$ & $\frac{a}{b}$ & 12.6 & 118.5 & Brass cap & 39.6 & 42.7 & partial & 3.1 & \\
\hline $399-1-18 \mathrm{C}$ & $2 / 3 / 1987$ & $\mathrm{c}$ & 12.6 & 118.5 & Brass cap & 39.6 & 42.7 & partial & 3.1 & \\
\hline 699-S22-E9A & $1 / 2 / 1992$ & & & 115.1 & $\begin{array}{l}\text { Top of 6" } \\
\text { protective casing }\end{array}$ & 7.7 & 12.2 & partial & & \\
\hline 699-S22-E 9D & $4 / 1 / 4,1992$ & & 8.1 & 116.5 & $\begin{array}{l}\text { Erass cap at } \\
\text { ground surface }\end{array}$ & 6.5 & 12.6 & \#REF! & 4.5 & Slug withdrawal data analyzed \\
\hline 699-S27-EgA & $1 / 1449992$ & & 12.9 & 120.0 & $\begin{array}{l}\text { Top of } 6^{\prime \prime} \\
\text { orotective casing }\end{array}$ & 11.3 & 17.5 & \#REF! & 4.6 & \\
\hline 699-S27-E9A & $1 / 2 / 1992$ & & & 120.0 & $\begin{array}{l}\text { Top of } 6^{\prime \prime} \\
\text { orotective casing }\end{array}$ & 11.3 & 17.5 & partial & & \\
\hline 699-S30-E10A & $1 / 29$ M990 & $\mathrm{a}$ & 13.3 & 120.6 & $\begin{array}{l}\text { Top of } 6^{\prime \prime} \\
\text { standpipe }\end{array}$ & 11.8 & 17.9 & & 4.6 & Early data \\
\hline 699-S30-E10A & 1/29/1990 & $\mathrm{b}$ & 13.3 & 120.6 & $\begin{array}{l}\text { Top of } 6^{\prime \prime} \\
\text { standpipe }\end{array}$ & 11.8 & 17.9 & & 4.6 & Late data \\
\hline 699-S30-E10日 & $2 / 2 / 1990$ & a & 13.1 & 120.5 & $\begin{array}{l}\begin{array}{l}\text { Top of 6" } \\
\text { standpipe }\end{array} \\
\text { s. }\end{array}$ & 11.8 & 17.9 & & 4.8 & Early data \\
\hline 699-S30-E10日 & 2021990 & $\mathrm{~b}$ & 131 & 1205 & $\begin{array}{l}\text { Top of } 6^{\prime \prime} \\
\text { standipe }\end{array}$ & 118 & 179 & & 48 & Late data \\
\hline 699-S31 E8A & $1 / 22 / 990$ & a & 6.6 & 115.2 & $\begin{array}{l}\text { Top of 6" } \\
\text { standpipe }\end{array}$ & 4.2 & 10.4 & & 3.8 & Early data \\
\hline 699-S31-E8A & $1 / 2211990$ & $\mathrm{~b}$ & 6.6 & 115.2 & $\begin{array}{l}\text { Top of } 6^{\prime \prime} \\
\text { standpipe }\end{array}$ & 4.2 & 10.4 & & 3.8 & Late data \\
\hline 699-S31-E10A & $2 M 4,1990$ & a & 11.1 & 118.2 & $\begin{array}{l}\text { Top of 6" } \\
\text { standpipe }\end{array}$ & 9.4 & 15.5 & & 4.4 & Early data \\
\hline 699-S31E10A & $2 M 4 / 1990$ & $\mathrm{~b}$ & 11.1 & 118.2 & $\begin{array}{l}\text { Top of 6" } \\
\text { standpipe }\end{array}$ & 9.4 & 15.5 & & 4.4 & Late data \\
\hline 699-S31-E10C & $1 / 29,1990$ & & 10.4 & 117.7 & $\begin{array}{l}\text { Top of 6" } \\
\text { standpipe }\end{array}$ & 14.6 & 17.7 & & 3.1 & Early data \\
\hline 699-S31-E10D & 1/24/1990 & a & 9.7 & 117.0 & $\begin{array}{l}\text { Top of } 6^{\prime \prime} \\
\text { standpipe }\end{array}$ & 5.9 & 12.1 & & 2.3 & Early data \\
\hline 699-S31-E10D & $1 / 244990$ & $\mathrm{~b}$ & 97 & 1170 & Top of 6" & 59 & 121 & & 23 & Late data \\
\hline 699-S32-E8 & $2 M 2 M 990$ & & 5.2 & 115.5 & $\begin{array}{l}\text { Top of } 6^{\prime \prime} \\
\text { standpipe }\end{array}$ & 22.5 & 25.5 & & 3.1 & Early data \\
\hline 699-S34-E10 & 2818990 & a & 8.9 & 117.5 & $\begin{array}{l}\text { Top of } 6^{\prime \prime} \\
\text { standpipe }\end{array}$ & 7.3 & 13.4 & & 4.5 & Early data \\
\hline 699-S34-E10 & $2 / 8 / 1990$ & $\mathrm{~b}$ & 8.9 & 117.5 & $\begin{array}{l}\text { Top of 6" } \\
\text { standpipe }\end{array}$ & 7.3 & 13.4 & & 4.5 & Late data \\
\hline 699-S37E11 & $2 / 2 / 1990$ & a & 14.2 & 122.7 & $\begin{array}{l}\text { Top of } 6 " \\
\text { standpipe }\end{array}$ & 12.1 & 18.2 & & 4.0 & Early data \\
\hline 699-537-E11 & $2 / 2 / 1990$ & 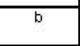 & 14.2 & 122.7 & $\begin{array}{l}\text { Top of 6" } \\
\text { Standpipe }\end{array}$ & 12.1 & 18.2 & & 4.0 & Late data \\
\hline
\end{tabular}




\begin{tabular}{|c|c|c|c|c|c|c|c|c|c|c|}
\hline mell name & $\begin{array}{c}\text { test start } \\
\text { date }\end{array}$ & sequence & $\begin{array}{c}\text { static depth } \\
\text { to water at } \\
\text { time of test, } \\
\text { belowref } \\
\text { point [m] } \\
\end{array}$ & $\begin{array}{c}\text { reference } \\
\text { point } \\
\text { elevation } \\
{[m]} \\
\end{array}$ & $\begin{array}{l}\text { reference datum } \\
\text { (ground surface, } \\
\text { top of casing, } \\
\text { brass cap, etc.) }\end{array}$ & $\begin{array}{l}\text { stress well open } \\
\text { interval, top } \\
\text { depth belowref } \\
\text { point [m] }\end{array}$ & $\begin{array}{c}\text { stress well open } \\
\text { interval, bottom } \\
\text { depth belowre f } \\
\text { point [m] }\end{array}$ & $\begin{array}{l}\text { peroent of } \\
\text { aquifer } \\
\text { penetration } \\
\text { stress well } \\
\text { (or } \\
\text { unknown) } \\
\end{array}$ & $\begin{array}{l}\text { saturated } \\
\text { open } \\
\text { interval } \\
\text { length [m] }\end{array}$ & comments \\
\hline 699-S38-E11 & $2 / 2 / 1990$ & $\mathrm{c}$ & 13.7 & 122.5 & $\begin{array}{l}\text { Top of 6" } \\
\text { standpipe }\end{array}$ & 12.4 & 18.5 & & 4.8 & Early data \\
\hline 699-S38-E12A & $2 \pi / 1990$ & & 16.0 & 124.4 & $\begin{array}{l}\text { Top of 6" } \\
\text { standpipe }\end{array}$ & 14.6 & 20.7 & & 4.7 & Early data \\
\hline 699-S38-E12B & $2 \pi M 990$ & & 16.1 & 124.5 & $\begin{array}{l}\text { Top of 6" } \\
\text { standpipe }\end{array}$ & 22.9 & 27.4 & & 4.6 & Early data \\
\hline 699-S41_E11A & $2 M / 1990$ & & 13.6 & 123.4 & Top of 4" casing & 11.6 & 17.7 & & 4.1 & Early data \\
\hline 699-S41-E12 & $2 / 28 / 1990$ & a & 15.3 & 123.5 & Top of 4" casing & 13.3 & 19.7 & & 4.4 & Early data \\
\hline 699-S41-E12 & $2 / 28 / 1990$ & b & 15.3 & 123.5 & Top of 4" casing & 13.3 & 19.7 & & 4.4 & Late data \\
\hline 699-S41-E13C & 288 M990 & & 17.6 & 126.2 & $\begin{array}{l}\text { Top of 6" } \\
\text { standpipe }\end{array}$ & 34.9 & 38.0 & & 3.1 & Early data \\
\hline 699-17-47 & $6 / 23 / 1969$ & & 53.3 & & $?$ & 53.3 & 103.6 & & 50.3 & Recovery data re-analyzed \\
\hline $699-40-39$ & 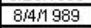 & & 38.0 & 165.3 & Brass cap & 61.3 & 64.5 & & 3.2 & \\
\hline $699-41-40$ & \begin{tabular}{|l|}
$7 \pi / 1989$ \\
\end{tabular} & & 37.7 & 166.5 & Brass cap & 50.0 & 53.1 & & 3.2 & \\
\hline $699-42-42 \mathrm{~B}$ & $5 / 26 / 1993$ & a & 49.4 & & Ground surface & 56.4 & & $\# R E F !$ & 5.8 & \\
\hline $699-42-428$ & $5 / 26 / 1993$ & $\mathrm{~b}$ & 49.4 & & Ground surface & 56.4 & & \#REF! & 5.8 & \\
\hline $699-42-42 \mathrm{~B}$ & 6 6MM993 & & 49.4 & & Ground surface & 56.4 & & \#REF! & 5.8 & \\
\hline $699-43-41 \mathrm{E}$ & $6 / 29 / 1989$ & & 38.3 & 168.0 & Brass cap & 41.2 & 44.4 & & 3.2 & \\
\hline $699-43-41 \mathrm{~F}$ & 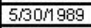 & & 38.5 & 168.0 & Brass cap & 50.3 & 53.6 & & & \\
\hline $699-43-44$ & \begin{tabular}{|l}
$1 / 28 / 2000$ \\
\end{tabular} & a & 53.3 & 176.6 & Brass cap & 52.1 & 58.2 & partial & 4.9 & \\
\hline $699-43-44$ & $1 / 28 / 2000$ & $\mathrm{~b}$ & 53.3 & 176.6 & Erass cap & 52.1 & 58.2 & partial & 4.9 & \\
\hline $699-43-44$ & \begin{tabular}{|l}
$4 \pi / 2000$ \\
\end{tabular} & & & 176.6 & Brass cap & 52.1 & 58.2 & partial & & No static depth to mater taken \\
\hline $699-44-43 \mathrm{~B}$ & $5 / 19 / 1989$ & a & 49.0 & & Ground surface & 52.7 & 53.7 & & 1.0 & temporary casing with open hole \\
\hline $699-44-438$ & $5 / 19 / 1989$ & $b$ & 49.0 & & Ground surface & 52.7 & 53.7 & & 1.0 & temporary casing with open hole \\
\hline $699-44-438$ & $5 / 19 / 1989$ & $\frac{a}{c}$ & 49.0 & & Ground surface & 52.7 & 53.7 & & 1.0 & temporary casing with open hole \\
\hline $699-44-438$ & $5 / 19 / 1989$ & d & 49.0 & & Ground surface & 52.7 & 53.7 & & 1.0 & temporary casing with open hole \\
\hline $699-44-438$ & $7 / 5 / 1989$ & a & 49.5 & 176.9 & Brass cap & 47.4 & 53.7 & & 4.2 & final casing screen \\
\hline $699-44-43 \mathrm{~B}$ & \begin{tabular}{|l|l|}
$715 / 989$ \\
\end{tabular} & $\mathrm{~b}$ & 49.5 & 176.9 & Brass cap & 47.4 & 53.7 & & 4.2 & final casing screen \\
\hline $699-77-54$ & $7 / 23 / 1957$ & & & & & & & & & \\
\hline $699-87-55$ & $7 / 2 / 1969$ & & & & & & & & & \\
\hline
\end{tabular}




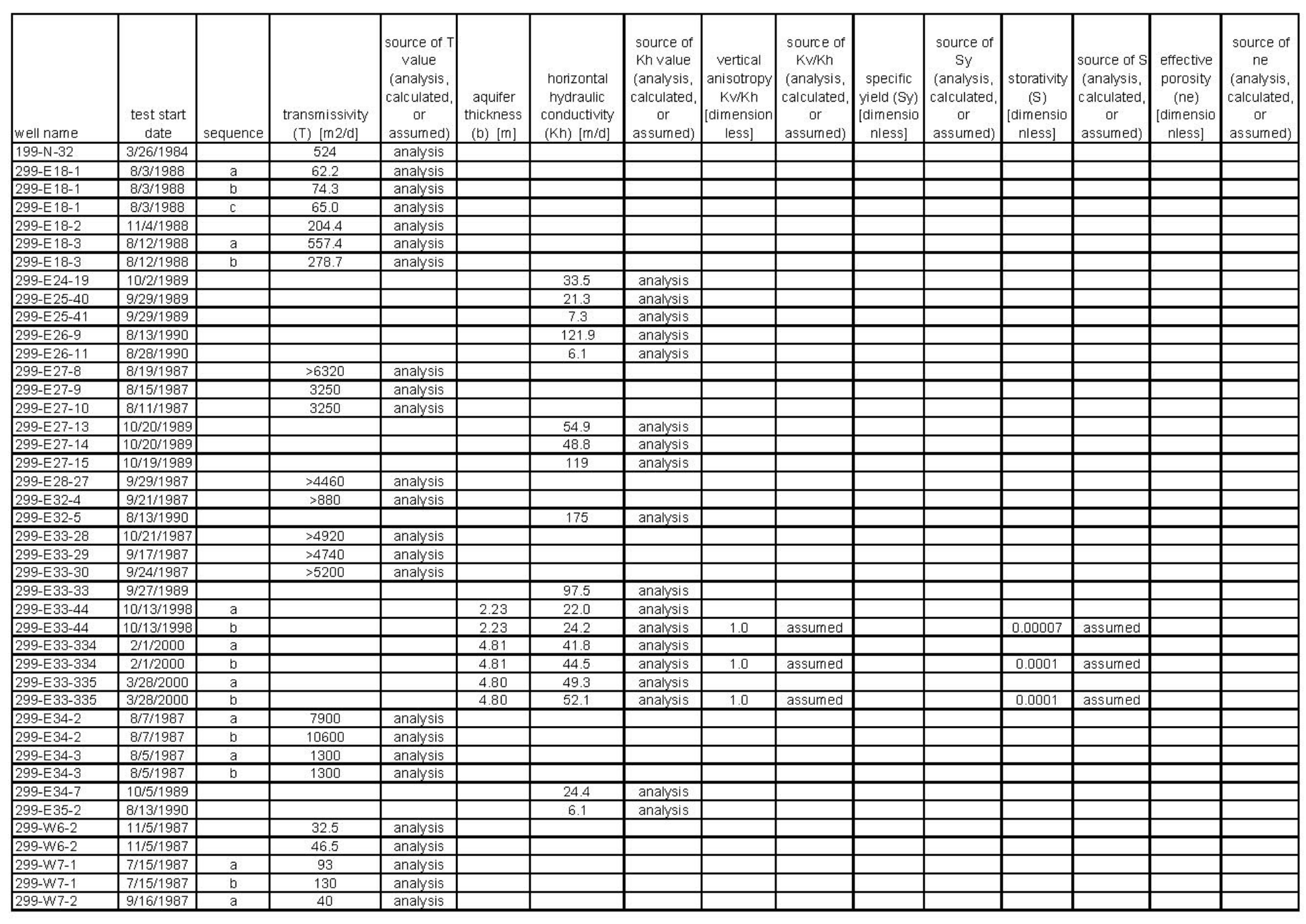

Table A.3 Analysis Results 


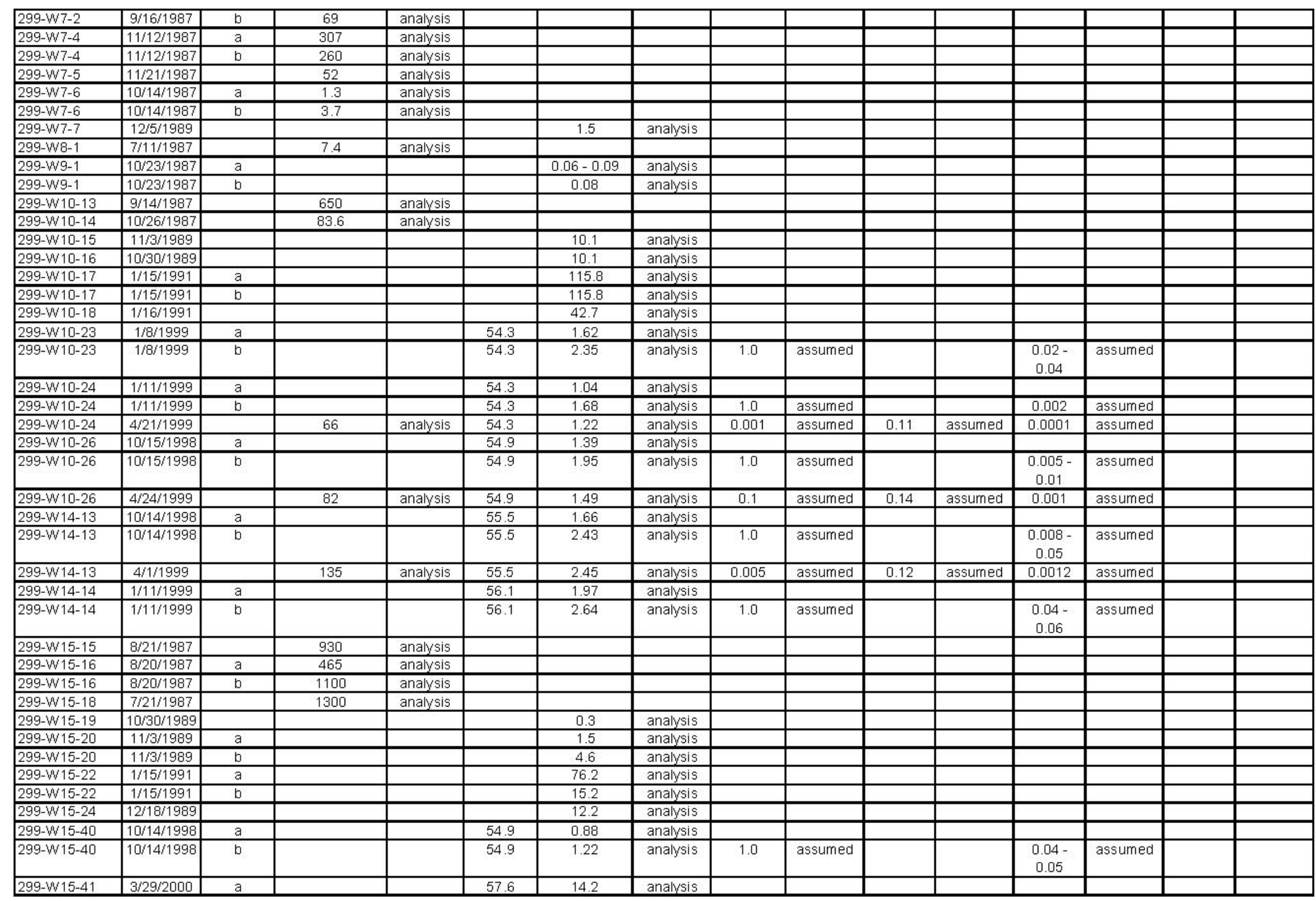

A. 15 


\begin{tabular}{|c|c|c|c|c|c|c|c|c|c|c|c|c|c|c|c|}
\hline 299-W15-41 & \begin{tabular}{ll|}
$3 / 29 / 2000$ \\
\end{tabular} & $\mathrm{~b}$ & & & 57.6 & 19.9 & analysis & 1.0 & assumed & & & $\begin{array}{c}0.0003- \\
0.0006\end{array}$ & assumed & & \\
\hline $299-W 15-41$ & $5 / 10 / 2000$ & & 1130 & analysis & 57.6 & 19.6 & analysis & 0.1 & assumed & 0.12 & assumed & 0.00012 & assumed & & \\
\hline $299-W 18-21$ & $7 / 14 / 1987$ & $\mathrm{a}$ & 120 & analysis & & & & & & & & & & & \\
\hline 299-W/18-21 & $7 / 14 / 1987$ & $\mathrm{~b}$ & 4740 & analysis & & & & & & & & & & & \\
\hline $299-W 18-22$ & \begin{tabular}{|l|}
$8 / 26 / 1987$ \\
\end{tabular} & & 39 & analysis & & & & & & & & & & & \\
\hline $299-W / 18-23$ & \begin{tabular}{|l|}
$6 / 22 / 1987$ \\
\end{tabular} & $\mathrm{a}$ & 2140 & analysis & & & & & & & & & & & \\
\hline $299-W 18-23$ & $6 / 22 / 1987$ & $\mathrm{~b}$ & 2510 & analysis & & & & & & & & & & & \\
\hline $299-W 18-24$ & $\begin{array}{l}7 / 17 / 1987 \\
\end{array}$ & & 4090 & analysis & & & & & & & & & & & \\
\hline 299-W18-25 & $12 / 12 / 1990$ & $\mathrm{a}$ & & & & 1.86 & analysis & & & & & & & & \\
\hline $299-W / 18-25$ & $12 / 12 / 1990$ & $\mathrm{~b}$ & & & & 1.86 & analysis & & & & & & & & \\
\hline $299-W 18-26$ & $11 / 22 / 1989$ & & & & & 3.0 & analysis & & & & & & & & \\
\hline 299-W19-31 & $1 / 17 / 1991$ & $\mathrm{a}$ & & & & 30.5 & analysis & & & & & & & & \\
\hline $299-W 19-31$ & $1 / 17 / 1991$ & $\mathrm{~b}$ & & & & 36.6 & analysis & & & & & & & & \\
\hline $299-W 19-32$ & 1/14/1991 & $a$ & & & & 0.093 & analysis & & & & & & & & \\
\hline 299-W19-32 & 1/144/1991 & $\mathrm{b}$ & & & & $0.093-0.42$ & analysis & & & & & & & & \\
\hline 299-W19-41 & $10 / 19 / 1998$ & $\mathrm{a}$ & & & 56.4 & 1.18 & analysis & & & & & & & & \\
\hline $299-W / 19-41$ & $10 / 19 / 1998$ & $\bar{b}$ & & & 56.4 & 1.69 & analysis & 1.0 & assumed & & & $\begin{array}{c}0.01- \\
0.04\end{array}$ & assumed & & \\
\hline 299-W19-42 & $10 / 15 / 1998$ & $\bar{a}$ & & & 56.4 & 7.06 & analysis & & & & & & & & \\
\hline $299-W 19-42$ & $10 / 15 / 1998$ & b & & & 56.4 & 9.5 & analysis & 1.0 & assumed & & & 0.0006 & assumed & & \\
\hline 299-W19-42 & $3 / 26 / 1999$ & & 345 & analysis & 56.4 & 6.12 & analysis & 0.1 & assumed & 0.17 & assumed & 0.00017 & assumed & & \\
\hline 299-W22-45 & $1 / 27 / 2000$ & $\mathrm{a}$ & & & 77.0 & $<0.4$ & analysis & & & & & & & & \\
\hline $299-W / 22-45$ & \begin{tabular}{l|l}
$1 / 27 / 2000$ \\
\end{tabular} & $\mathrm{~b}$ & & & 77.0 & 0.14 & analysis & 1.0 & assumed & & & $\begin{array}{c}0.00008- \\
0.0002\end{array}$ & assumed & & \\
\hline $299-W 22-46$ & $4 / 13 / 2000$ & $\mathrm{a}$ & & & 73.5 & 2.43 & analysis & & & & & & & & \\
\hline $299-W 22-46$ & $4 / 13 / 2000$ & $\mathrm{~b}$ & & & 73.5 & 3.37 & analysis & 1.0 & assumed & & & $\begin{array}{l}0.004- \\
0.008\end{array}$ & assumed & & \\
\hline $299-W 22-48$ & $1 / 26 / 2000$ & $\mathrm{a}$ & & & 70.1 & 1.42 & analysis & & & & & & & & \\
\hline $299-W 22-48$ & 1/26/2000 & $\bar{b}$ & & & 70.1 & 1.86 & analysis & 1.0 & assumed & & & $\begin{array}{c}0.0001- \\
0.001\end{array}$ & assurned & & \\
\hline $299-W 22-48$ & $5 / 22 / 2000$ & & 125 & analysis & 70.1 & 1.78 & analysis & 0.1 & assumed & 0.09 & assumed & 0.00009 & assumed & & \\
\hline $299-W 22-49$ & $1 / 27 / 2000$ & $a$ & & & 72.5 & 6.04 & analysis & & & & & & & & \\
\hline 299-W22-49 & $1 / 27 / 2000$ & $\mathrm{~b}$ & & & 72.5 & 7.97 & analysis & 1.0 & assumed & & & $\begin{array}{c}0.0004- \\
0.001\end{array}$ & assumed & & \\
\hline $299-W 22-49$ & $4 / 20 / 2000$ & & 783 & analysis & 72.5 & 10.8 & analysis & 0.1 & assumed & 0.12 & assumed & 0.00012 & assumed & & \\
\hline 299-W22-50 & $4 / 10 / 2000$ & $\mathrm{a}$ & & & 73.5 & 4.24 & analysis & & & & & & & & \\
\hline $299-W 22-50$ & \begin{tabular}{|l|}
$4 / 10 / 2000$ \\
\end{tabular} & $\mathrm{~b}$ & & & 73.5 & 5.70 & analysis & 1.0 & assumed & & & $\begin{array}{c}0.005- \\
0.002\end{array}$ & assumed & & \\
\hline $299-W 22-50$ & \begin{tabular}{|l|}
$5 / 31 / 2000$ \\
\end{tabular} & & 385 & analysis & 73.5 & 5.24 & analysis & 0.1 & assumed & 0.11 & assumed & 0.0011 & assumed & & \\
\hline 299-W22-79 & \begin{tabular}{|l|}
$10 / 19 / 1998$ \\
\end{tabular} & $\bar{a}$ & & & 53.3 & 4.18 & analvsis & & & & & & & & \\
\hline $299-W 22-79$ & \begin{tabular}{|l|}
$10 / 19 / 1998$ \\
\end{tabular} & $\bar{b}$ & & & 53.3 & 5.4 & analysis & 1.0 & assumed & & & $\begin{array}{c}0.02- \\
0.04\end{array}$ & assumed & & \\
\hline $299-W 22-80$ & $10 / 25 / 2000$ & $\mathrm{a}$ & & & & 11.3 & analysis & & & & & & & & \\
\hline $299-W 22-80$ & $10 / 25 / 2000$ & $\mathrm{~b}$ & & & & 15.4 & analysis & & & & & & & & \\
\hline $299-W 22-81$ & $4 / 30 / 2001$ & $\mathrm{a}$ & & & & 1.77 & analvsis & & & & & & & & \\
\hline $299-W 22-81$ & 4/30/2001 & $\mathrm{b}$ & & & & 2.27 & analysis & & & & & & & & \\
\hline 299-W22-82 & $4 / 25 / 2001$ & $\mathrm{a}$ & & & & 1.16 & analysis & & & & & & & & \\
\hline 299-W22-82 & $4 / 25 / 2001$ & $\mathrm{~b}$ & & & & 1.45 & analysis & & & & & & & & \\
\hline
\end{tabular}

A. 16 


\begin{tabular}{|c|c|c|c|c|c|c|c|c|c|c|c|c|c|c|c|}
\hline 299-W/22-83 & $4 / 26 / 2001$ & $\mathrm{a}$ & & & & 0.78 & analysis & & & & & & & & \\
\hline $299-W 22-83$ & $4 / 26 / 2001$ & $\mathrm{~b}$ & & & & 1.00 & analysis & & & & & & & & \\
\hline 299-W22-84 & $12 / 4 / 2001$ & $a$ & & & & 1.15 & analysis & & & & & & & & \\
\hline $299-W 22-84$ & $12 / 4 / 2001$ & $\mathrm{~b}$ & & & & 1.51 & analysis & & & & & & & & \\
\hline 299-W22-85 & $12 / 5 / 2001$ & $\mathrm{a}$ & & & & 5.69 & analysis & & & & & & & & \\
\hline $299-W 22-85$ & $12 / 5 / 2001$ & $\mathrm{~b}$ & & & & 7.73 & analysis & & & & & & & & \\
\hline 299-W23-13 & $12 / 12 / 1990$ & & & & & 8.4 & analysis & & & & & & & & \\
\hline 299-W23-14 & $5 / 12 / 1991$ & $\mathrm{a}$ & & & & 0.13 & analysis & & & & & & & & \\
\hline 299-W23-14 & $5 / 12 / 1991$ & $\mathrm{~b}$ & & & & 0.13 & analysis & & & & & & & & \\
\hline 299-W/23-15 & $1 / 24 / 2000$ & $\mathrm{a}$ & & & 75.6 & $<0.3$ & analysis & & & & & & & & \\
\hline 299-W23-15 & $1 / 24 / 2000$ & $\mathrm{~b}$ & & & 75.6 & 0.05 & analysis & 1.0 & assumed & & & 0.0013 & assumed & & \\
\hline $299-W 23-20$ & $11 / 1 / 2000$ & $\mathrm{a}$ & & & & 16.9 & analysis & & & & & & & & \\
\hline 299-W23-20 & $11 / 1 / 2000$ & $\mathrm{~b}$ & & & & 17.2 & analysis & & & & & & & & \\
\hline 299-W23-21 & $1 / 30 / 2001$ & $\mathrm{a}$ & & & & 0.59 & analysis & & & & & & & & \\
\hline $299-W 23-21$ & $1 / 30 / 2001$ & $\mathrm{~b}$ & & & & 0.75 & analysis & & & & & & & & \\
\hline $299-W 26-8$ & $5 / 31 / 1990$ & & & & & 1.5 & analysis & & & & & & & & \\
\hline $299-W 26-9$ & $5 / 3 / 1990$ & & & & & 9.1 & analysis & & & & & & & & \\
\hline $299-W 26-10$ & $5 / 31 / 1990$ & & & & & 22.9 & analysis & & & & & & & & \\
\hline 299-W26-11 & $5 / 31 / 1990$ & $\mathrm{a}$ & & & & 0.0018 & analysis & & & & & & & & \\
\hline $299-W 26-11$ & 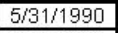 & $\mathrm{b}$ & & & & 0.000012 & analysis & & & & & & & & \\
\hline $299-W 26-12$ & $5 / 10 / 1990$ & $\mathrm{a}$ & & & & 1.5 & analysis & & & & & & & & \\
\hline $299-W 26-12$ & $5 / 10 / 1990$ & $\mathrm{~b}$ & & & & 4.9 & analysis & & & & & & & & \\
\hline $299-W 26-13$ & $1 / 25 / 2000$ & $\mathrm{a}$ & & & 76.2 & $\angle 0.42$ & analysis & & & & & & & & \\
\hline $299-W 26-13$ & $1 / 25 / 2000$ & $\mathrm{~b}$ & & & 76.2 & 0.09 & analysis & 1.0 & assumed & & & 0.0027 & assumed & & \\
\hline $399-1-9$ & $\begin{array}{l}3 / 2 / 1987 \\
\end{array}$ & & 5.6 & analysis & 6.1 & & & & & & & & & & \\
\hline $399-1-10$ & $11 / 25 / 1986$ & $\mathrm{a}$ & 10220 & analysis & & & & & & & & & & & \\
\hline $399-1-10$ & $11 / 25 / 1986$ & $\mathrm{~b}$ & 8090 & analysis & & & & & & & & & & & \\
\hline $399-1-10$ & $11 / 25 / 1986$ & c & 24200 & analysis & & & & & & & & & & & \\
\hline $399-1-13$ & $11 / 5 / 1986$ & $\mathrm{a}$ & 9300 & analysis & & & & & & & & & & & \\
\hline $399-1-13$ & 11/5/1986 & $\mathrm{b}$ & 9850 & analysis & & & & & & & & & & & \\
\hline $399-1-13$ & $11 / 5 / 1986$ & c & 11100 & analysis & & & & & & & & & & & \\
\hline $399-1-14$ & $11 / 12 / 1986$ & & 17650 & analysis & & & & & & & & & & & \\
\hline $399-1-16 \mathrm{~A}$ & $2 / 26 / 1987$ & $\mathrm{a}$ & 557.7 & analysis & 24.4 & & & & & & & & & & \\
\hline $399-1-16 \mathrm{~A}$ & $2 / 26 / 1987$ & $\mathrm{~b}$ & 1403.6 & analysis & 24.4 & & & & & & & & & & \\
\hline $399-1-16 \mathrm{~A}$ & $2 / 26 / 1987$ & c & 650.7 & analysis & 24.4 & & & & & & & & & & \\
\hline $399-1-16 \mathrm{~B}$ & $2 / 19 / 1987$ & $\mathrm{a}$ & & & 17.7 & & & & & & & & & & \\
\hline $399-1-16 \mathrm{~B}$ & 2/19/1987 & $\mathrm{b}$ & & & 17.7 & & & & & & & & & & \\
\hline $399-1-16 \mathrm{~B}$ & $2 / 24 / 1987$ & $\mathrm{a}$ & & & 17.7 & & & & & & & & & & \\
\hline $399-1-16 \mathrm{~B}$ & $2 / 24 / 1987$ & $\mathrm{~b}$ & & & 17.7 & & & & & & & & & & \\
\hline $399-1-16 \mathrm{C}$ & $2 / 17 / 1987$ & $\mathrm{a}$ & 1.4 & analysis & 16.46 & & & & & & & & & & \\
\hline $399-1-16 \mathrm{C}$ & $2 / 17 / 1987$ & $\mathrm{~b}$ & 0.9 & analysis & 16.46 & & & & & & & & & & \\
\hline $399-1-16 \mathrm{C}$ & $2 / 17 / 1987$ & c & 8.4 & analysis & 16.46 & & & & & & & & & & \\
\hline $399-1-17 \mathrm{~B}$ & $2 / 9 / 1987$ & $\mathrm{a}$ & 23.2 & analysis & 15.2 & & & & & & & & & & \\
\hline $399-1-17 \mathrm{~B}$ & $2 / 9 / 1987$ & $\mathrm{~b}$ & 125.5 & analysis & 15.2 & & & & & & & & & & \\
\hline $399-1-17 \mathrm{~B}$ & $2 / 9 / 1987$ & c & 93 & analysis & 15.2 & & & & & & & & & & \\
\hline $399-1-17 \mathrm{C}$ & $2 / 11 / 1987$ & $\mathrm{a}$ & 40 & analysis & 1.5 & & & & & & & & & & \\
\hline $399-1-17 \mathrm{C}$ & $2 / 11 / 1987$ & $\mathrm{~b}$ & 102.2 & analysis & 1.5 & & & & & & & & & & \\
\hline $399-1-17 \mathrm{C}$ & $2 / 11 / 1987$ & c & 185.9 & analysis & 1.5 & & & & & & & & & & \\
\hline $399-1-18 \mathrm{~A}$ & $11 / 11 / 1986$ & $\mathrm{a}$ & 58000 & analysis & 6.1 & & & & & & & & & & \\
\hline
\end{tabular}




\begin{tabular}{|c|c|c|c|c|c|c|c|c|c|c|c|c|c|c|c|}
\hline $399-1-18 \mathrm{~A}$ & \begin{tabular}{|l|}
$11 / 11 / 1986$ \\
\end{tabular} & $b$ & 111500 & analysis & 6.1 & & & & & & & & & & \\
\hline 399-1-18B & \begin{tabular}{|l|}
$1 / 29 / 1987$ \\
\end{tabular} & $a$ & 13 & analysis & 16.15 & & & & & & & & & & \\
\hline $399-1-18 \mathrm{~B}$ & $1 / 29 / 1987$ & $\mathrm{~b}$ & 5.6 & analysis & 16.15 & & & & & & & & & & \\
\hline $399-1-18 \mathrm{C}$ & $2 / 3 / 1987$ & $\mathrm{a}$ & 3.7 & analysis & & & & & & & & & & & \\
\hline $399-1-18 \mathrm{C}$ & $2 / 3 / 1987$ & $\mathrm{~b}$ & 13 & analysis & 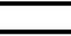 & & & & & & & & & & \\
\hline $399-1-18 \mathrm{C}$ & 2/3/1987 & c & 8.7 & analysis & & & & & & & & & & & \\
\hline 699-S22-E9A & $1 / 2 / 1992$ & & & & 5.5 & 9.1 & analysis & & & & & & & & \\
\hline 699-S22-E9D & $4 / 14 / 1992$ & & & & 5.5 & 10.7 & analysis & & & & & & & & \\
\hline 699-S27-E9A & $1 / 14 / 1992$ & & 451 & analysis & 10.3 & & & & & & & & & & \\
\hline 699-S27-E9A & \begin{tabular}{ll|}
$1 / 2 / 1992$ \\
\end{tabular} & & & & 10.3 & 5.2 & analysis & & & & & & & & \\
\hline 699-S30-E10A & 1/29/1990 & $\mathrm{a}$ & & & & 0.9 & analysis & & & & & & & & \\
\hline 699-S30-E10A & 1/29/1990 & $\mathrm{b}$ & & & & 1.5 & analysis & & & & & & & & \\
\hline 699-S30-E10B & $2 / 2 / 1990$ & $\mathrm{a}$ & & & & 1.2 & analysis & & & & & & & & \\
\hline 699-S30-E10B & $2 / 2 / 1990$ & $\mathrm{~b}$ & & & & 0.9 & analysis & & & & & & & & \\
\hline 699-S31-E8A & $1 / 22 / 1990$ & $a$ & & & & 46.5 & analysis & & & & & & & & \\
\hline 699-S31-EBA & $1 / 22 / 1990$ & $\mathrm{~b}$ & & & & 62 & analysis & & & & & & & & \\
\hline 699-S31-E10A & $2 / 14 / 1990$ & $\mathrm{a}$ & & & & 5.18 & analysis & & & & & & & & \\
\hline 699-S31-E10A & \begin{tabular}{|l|}
$2 / 14 / 1990$ \\
\end{tabular} & $\mathrm{~b}$ & & & & 5.79 & analysis & & & & & & & & \\
\hline 699-S31-E10C & & & & & & & analysic & & & & & & & & \\
\hline 699-S31-E10D & $1 / 24 / 1990$ & a & & & & 25.1 & analysis & & & & & & & & \\
\hline 699-S31-E10D & $1 / 24 / 1990$ & $\bar{b}$ & & & & 35.7 & analysis & & & & & & & & \\
\hline 699-S32-E8 & $2 / 12 / 1990$ & & & & & 0.3 & analysis & & & & & & & & \\
\hline 699-S34-E10 & \begin{tabular}{|l|}
$2 / 8 / 1990$ \\
\end{tabular} & $\mathrm{a}$ & & & & 6.7 & analysis & & & & & & & & \\
\hline 699-S34-E10 & $2 / 8 / 1990$ & $\mathrm{~b}$ & & & & 9.45 & analysis & & & & & & & & \\
\hline 699-S37-E11 & $2 / 2 / 1990$ & $\mathrm{a}$ & & & & 9.45 & analysis & & & & & & & & \\
\hline 699-S37-E11 & $2 / 2 / 1990$ & $\mathrm{~b}$ & & & & 16.46 & analysis & & & & & & & & \\
\hline 699-S38-E11 & $2 / 2 / 1990$ & c & & & & 7.92 & analysis & & & & & & & & \\
\hline 699-S38-E12A & $2 / 7 / 1990$ & & & & & 10.67 & analysis & & & & & & & & \\
\hline 699-S38-E12B & $2 / 7 / 1990$ & & & & & 2.74 & analysis & & & & & & & & \\
\hline 699-S41-E11A & $2 / 1 / 1990$ & & & & & 4.72 & analysis & & & & & & & & \\
\hline 699-S41-E12 & $2 / 28 / 1990$ & $\mathrm{a}$ & & & & 26.8 & analysis & & & & & & & & \\
\hline 699-S41-E12 & $2 / 28 / 1990$ & $b$ & & & & 42.1 & analysis & & & & & & & & \\
\hline 699-S41-E13C & $2 / 8 / 1990$ & & & & & 0.061 & analysis & & & & & & & & \\
\hline $699-17-47$ & $6 / 23 / 1969$ & & 474 & analysis & & & & & & & & & & & \\
\hline 699-40-39 & $8 / 4 / 1989$ & & 0.418 & analysis & & & & & & & & & & & \\
\hline $699-41-40$ & $7 / 7 / 1989$ & & 0.251 & analysis & & & & & & & & & & & \\
\hline $699-42-42 B$ & $5 / 26 / 1993$ & $\mathrm{a}$ & 7.5 & analysis & 12.8 & & & 0.1 & assumed & & & 0.0001 & assumed & & \\
\hline $699-42-42 \mathrm{~B}$ & $5 / 26 / 1993$ & $\mathrm{~b}$ & 6.2 & analysis & 12.8 & & & & & & & & & & \\
\hline $699-42-42 B$ & $6 / 1 / 1993$ & & 8.5 & analysis & 12.8 & & & 0.45 & assumed & & & 0.0001 & assumed & & \\
\hline $699-43-41 \mathrm{E}$ & $6 / 29 / 1989$ & & 1.58 & analysis & & & & & & & & & & & \\
\hline $699-43-41 F$ & $5 / 30 / 1989$ & & 0.098 & analysis & & & & & & & & & & & \\
\hline $699-43-44$ & $1 / 28 / 2000$ & $\mathrm{a}$ & & & 5.21 & 1.74 & analysis & & & & & & & & \\
\hline $699-43-44$ & $1 / 28 / 2000$ & b & & & 5.21 & 1.95 & analysis & 1.0 & assumed & & & 0.00001 & assumed & & \\
\hline $699-43-44$ & $4 / 7 / 2000$ & & 8.85 & analysis & 5.21 & 1.70 & analysis & 0.5 & assumed & 0.16 & assumed & 0.0002 & assumed & & \\
\hline 699-44-43B & $5 / 19 / 1989$ & a & & & & 0.12 & analysis & & & & & & & & \\
\hline
\end{tabular}

A. 18 


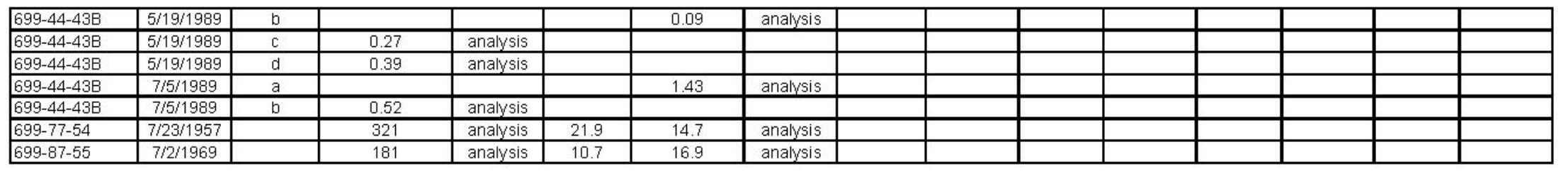




\begin{tabular}{|c|c|c|c|c|c|c|c|c|c|c|}
\hline well name & $\begin{array}{l}\text { test start } \\
\text { date }\end{array}$ & sequence & $\begin{array}{l}\text { test type (constant } \\
\text { rate/step/slug) }\end{array}$ & $\begin{array}{r}\begin{array}{c}\text { Constant } \\
\text { Inform }\end{array} \\
\end{array}$ & $\begin{array}{l}\text { Rate Test } \\
\text { nation }\end{array}$ & Step DI & down Test In & nformation & & \\
\hline & & & & $\begin{array}{l}\text { purnping } \\
\text { duration } \\
\text { [min] }\end{array}$ & $\begin{array}{l}\text { flow rate } \\
\text { [L min] }\end{array}$ & $\begin{array}{l}\text { total } \\
\text { pumping } \\
\text { duration } \\
\text { [min] }\end{array}$ & $\begin{array}{l}\text { min flow } \\
\text { rate [L/min] }\end{array}$ & $\begin{array}{l}\text { max flow } \\
\text { rate [ } \mathrm{L} / \mathrm{min}]\end{array}$ & $\begin{array}{l}\text { calculated } \\
\text { head loss - } \\
\text { friction [m] }\end{array}$ & $\begin{array}{l}\text { calculated } \\
\text { well efficiency } \\
\text { [percentage] }\end{array}$ \\
\hline $199-N-32$ & $3 / 26 / 1984$ & & constant rate & 1440 & $\begin{array}{r}378.5 \\
\end{array}$ & & & & & \\
\hline 299-E18-1 & $8 / 3 / 1988$ & $\mathrm{a}$ & constant rate & 236 & 50.3 & & & & & \\
\hline 299-E18-1 & 8/3/1988 & $\mathrm{b}$ & constant rate & 236 & 50.3 & & & & & \\
\hline 299-E18-1 & 8/3/1988 & c & constant rate & 236 & 50.3 & & & & & \\
\hline 299-E18-2 & $11 / 4 / 1988$ & & constant rate & 220 & 34.1 & & & & & \\
\hline 299-E18-3 & $8 / 12 / 1988$ & $\mathrm{a}$ & constant rate & 300 & 128.7 & & & & & \\
\hline 299-E18-3 & $8 / 12 / 1988$ & $\mathrm{~b}$ & constant rate & 300 & 128.7 & & & & & \\
\hline 299-E27-10 & $8 / 11 / 1987$ & & constant rate & 480 & 397.4 & & & & & \\
\hline 299-E27-8 & $8 / 19 / 1987$ & & constant rate & 375 & 726.7 & & & & & \\
\hline 299-E27-9 & $8 / 15 / 1987$ & & constant rate & 570 & 643.5 & & & & & \\
\hline 299-E28-27 & $9 / 29 / 1987$ & & constant rate & 240 & 514.8 & & & & & \\
\hline 299-E32-4 & $9 / 21 / 1987$ & & constant rate & 240 & 102.2 & & & & & \\
\hline 299-E33-28 & $10 / 21 / 1987$ & & constant rate & 240 & 567.8 & & & & & \\
\hline 299-E33-29 & $9 / 17 / 1987$ & & constant rate & 180 & 548.8 & & & & & \\
\hline 299-E33-30 & $9 / 24 / 1987$ & & constant rate & 218 & 605.6 & & & & & \\
\hline 299-E34-2 & $8 / 7 / 1987$ & $\mathrm{a}$ & constant rate & 225 & 734.3 & & & & & \\
\hline 299-E34-2 & 8/7/1987 & $\mathrm{b}$ & constant rate & 225 & 734.3 & & & & & \\
\hline 299-E34-3 & $8 / 5 / 1987$ & $\mathrm{a}$ & constant rate & 180 & 227.1 & & & & & \\
\hline 299-E34-3 & 8/5/1987 & $b$ & constant rate & 180 & 227.1 & & & & & \\
\hline $299-W 10-13$ & $9 / 14 / 1987$ & & constant rate & 480 & 113.6 & & & & & \\
\hline 299-W10-14 & $10 / 26 / 1987$ & & constant rate & 225 & 53.0 & & & & & \\
\hline $299-W 10-24$ & $4 / 21 / 1999$ & & constant rate & 235 & 41.2 & & & & & \\
\hline $299-W 10-26$ & $4 / 24 / 1999$ & & constant rate & 213 & 39.5 & & & & & \\
\hline 299-W14-13 & $4 / 1 / 1999$ & & constant rate & 270 & 48.9 & & & & & \\
\hline 299-W15-15 & $8 / 21 / 1987$ & & constant rate & 360 & 75.7 & & & & & \\
\hline 299-W15-16 & $8 / 20 / 1987$ & $a$ & constant rate & 420 & 302.8 & & & & & \\
\hline 299-W15-16 & $8 / 20 / 1987$ & $\mathrm{~b}$ & constant rate & 420 & 302.8 & & & & & \\
\hline 299-W15-18 & $7 / 21 / 1987$ & & constant rate & 450 & 329.3 & & & & & \\
\hline 299-W/15-41 & $5 / 10 / 2000$ & & constant rate & 150 & 60.4 & & & & & \\
\hline 299-W18-21 & $7 / 14 / 1987$ & $\mathrm{a}$ & constant rate & 480 & 219.5 & & & & & \\
\hline 299-W18-21 & $7 / 14 / 1987$ & $\mathrm{~b}$ & constant rate & 480 & 219.5 & & & & & \\
\hline 299-W18-22 & $8 / 26 / 1987$ & & constant rate & 480 & 193 & & & & & \\
\hline $299-W / 18-23$ & $6 / 22 / 1987$ & $\mathrm{a}$ & constant rate & 480 & 321.7 & & & & & \\
\hline 299-W/18-23 & $6 / 22 / 1987$ & $\mathrm{~b}$ & constant rate & 480 & 321.7 & & & & & \\
\hline 299-W18-24 & $7 / 17 / 1987$ & & constant rate & 450 & 378.5 & & & & & \\
\hline $299-W / 19-42$ & $3 / 26 / 1999$ & & constant rate & 307 & 56.8 & & & & & \\
\hline $299-W 22-48$ & $5 / 22 / 2000$ & & constant rate & 220 & 6.96 & & & & & \\
\hline 299-W/22-49 & $4 / 20 / 2000$ & & constant rate & 195 & 42.2 & & & & & \\
\hline 299-W22-50 & $5 / 31 / 2000$ & & constant rate & 121 & 29.2 & & & & & \\
\hline 299-W6-2 & 11/5/1987 & & constant rate & 300 & 83.3 & & & & & \\
\hline 299-W6-2 & $11 / 5 / 1987$ & & constant rate & 300 & 83.3 & & & & & \\
\hline 299-W7-1 & $7 / 15 / 1987$ & $a$ & constant rate & 480 & 66.2 & & & & & \\
\hline $299-W 7-1$ & $7 / 15 / 1987$ & $\bar{b}$ & constant rate & 480 & 66.2 & & & & & \\
\hline $299-W 7-2$ & $9 / 16 / 1987$ & $\mathrm{a}$ & constant rate & 480 & 39.7 & & & & & \\
\hline 299-W7-2 & $9 / 16 / 1987$ & $\mathrm{~b}$ & constant rate & 480 & 39.7 & & & & & \\
\hline $299-W 7-4$ & $11 / 12 / 1987$ & $\mathrm{a}$ & constant rate & 420 & 181.7 & & & & & \\
\hline $299-W 7-4$ & $11 / 12 / 1987$ & $\mathrm{~b}$ & constant rate & 420 & 181.7 & & & & & \\
\hline $299-W 7-5$ & $11 / 21 / 1987$ & & constant rate & 360 & 16.7 & & & & & \\
\hline 299-W7-6 & $10 / 14 / 1987$ & $\mathrm{a}$ & constant rate & 480 & 26.5 & & & & & \\
\hline 299-W7-6 & $10 / 14 / 1987$ & $b$ & constant rate & 480 & 26.5 & & & & & \\
\hline 299-W8-1 & $7 / 11 / 1987$ & & constant rate & 360 & 32.9 & & & & & \\
\hline $399-1-10$ & $11 / 25 / 1986$ & $\mathrm{a}$ & constant rate & 240 & 2384.6 & & & & & \\
\hline $399-1-10$ & $11 / 25 / 1986$ & $b$ & constant rate & 240 & 2384.6 & & & & & \\
\hline $399-1-10$ & $11 / 25 / 1986$ & c & constant rate & 240 & 2384.6 & & & & & \\
\hline 399-1-13 & $11 / 5 / 1986$ & $\mathrm{a}$ & constant rate & 132 & 2498 & & & & & \\
\hline $399-1-13$ & 11/5/1986 & $\mathrm{b}$ & constant rate & 132 & 2498 & & & & & \\
\hline 399-1-13 & $11 / 5 / 1986$ & C & constant rate & 132 & 2498 & & & & & \\
\hline $399-1-14$ & $11 / 12 / 1986$ & & constant rate & 420 & 2138.5 & & & & & \\
\hline $399-1-16 \mathrm{~A}$ & $2 / 26 / 1987$ & $\mathrm{a}$ & constant rate & 180 & 113.6 & & & & & \\
\hline 399-1-16A & $2 / 26 / 1987$ & $b$ & constant rate & 180 & 113.6 & & & & & \\
\hline
\end{tabular}

Table A.4 Constant Rate and Step Drawdown Test Information 


\begin{tabular}{|c|c|c|c|c|c|c|c|c|c|c|}
\hline well name & $\begin{array}{l}\text { test start } \\
\text { date }\end{array}$ & sequence & $\begin{array}{l}\text { test type (constant } \\
\text { rate/step/slug) }{ }^{*}\end{array}$ & $\begin{array}{l}\text { Constant } \\
\text { Inform }\end{array}$ & $\begin{array}{l}\text { e Test } \\
\text { on }\end{array}$ & Step Draw & down Test In & Information & & \\
\hline 399-1-16A & $2 / 26 / 1987$ & $\mathrm{C}$ & constant rate & 180 & 113.6 & & & & & \\
\hline 399-1-16B & $2 / 19 / 1987$ & $a$ & constant rate & 800 & 45.4 & & & & & \\
\hline $399-1-16 \mathrm{~B}$ & $2 / 19 / 1987$ & $\mathrm{~b}$ & constant rate & 800 & 45.4 & & & & & \\
\hline 399-1-16B & $2 / 24 / 1987$ & $a$ & constant rate & 300 & 75.7 & & & & & \\
\hline $399-1-16 \mathrm{~B}$ & $2 / 24 / 1987$ & $\mathrm{~b}$ & constant rate & 300 & 75.7 & & & & & \\
\hline $399-1-16 \mathrm{C}$ & $2 / 17 / 1987$ & $\mathrm{a}$ & constant rate & 480 & 10.6 & & & & & \\
\hline $399-1-16 \mathrm{C}$ & $2 / 17 / 1987$ & $\mathrm{~b}$ & constant rate & 480 & 10.6 & & & & & \\
\hline $399-1-16 \mathrm{C}$ & $2 / 17 / 1987$ & C & constant rate & 480 & 10.6 & & & & & \\
\hline 399-1-17B & 2/9/1987 & $a$ & constant rate & 315 & 87.06 & & & & & \\
\hline 399-1-17B & $2 / 9 / 1987$ & $\mathrm{~b}$ & constant rate & 315 & 87.06 & & & & & \\
\hline 399-1-17B & $2 / 9 / 1987$ & C & constant rate & 315 & 87.06 & & & & & \\
\hline $399-1-17 \mathrm{C}$ & $2 / 11 / 1987$ & a & constant rate & 360 & 106.0 & & & & & \\
\hline $399-1-17 \mathrm{C}$ & $2 / 11 / 1987$ & $\mathrm{~b}$ & constant rate & 360 & 106.0 & & & & & \\
\hline $399-1-17 C$ & $2 / 11 / 1987$ & $\mathrm{C}$ & constant rate & 360 & 106.0 & & & & & \\
\hline $399-1-18 \mathrm{~A}$ & 11/11/1986 & $\mathrm{a}$ & constant rate & 120 & 2573.8 & & & & & \\
\hline $399-1-18 \mathrm{~A}$ & $11 / 11 / 1986$ & $b$ & constant rate & 120 & 2573.8 & & & & & \\
\hline 399-1-18B & $1 / 29 / 1987$ & $a$ & constant rate & 480 & 15.9 & & & & & \\
\hline 399-1-18B & $1 / 29 / 1987$ & $\mathrm{~b}$ & constant rate & 480 & 15.9 & & & & & \\
\hline $399-1-18 \mathrm{C}$ & $2 / 3 / 1987$ & $a$ & constant rate & 480 & 15.1 & & & & & \\
\hline $399-1-18 \mathrm{C}$ & 2/3/1987 & $b$ & constant rate & 480 & 15.1 & & & & & \\
\hline $399-1-18 C$ & $2 / 3 / 1987$ & c & constant rate & 480 & 15.1 & & & & & \\
\hline $399-1-9$ & $3 / 2 / 1987$ & & constant rate & 480 & 10.2 & & & & & \\
\hline $699-17-47$ & $6 / 23 / 1969$ & & constant rate & 420 & 340.7 & & & & & \\
\hline 699-42-42B & $6 / 1 / 1993$ & & constant rate & 1440 & 18.5 & & & & & \\
\hline $699-43-44$ & $4 / 7 / 2000$ & & constant rate & 213 & 14.5 & & & & & \\
\hline $699-77-54$ & $7 / 23 / 1957$ & & constant rate & & & & & & & \\
\hline 699-87-55 & $7 / 2 / 1969$ & & constant rate & & & & & & & \\
\hline 699-S27-E9A & $1 / 14 / 1992$ & & step & & & 244 & 7.42 & 35.96 & 0.52 & \\
\hline
\end{tabular}




\begin{tabular}{|c|c|c|c|}
\hline well name & test start date & sequence & slugging method (injection, withdrawal) \\
\hline 299-E24-19 & $10 / 2 / 1989$ & & slug injection and withdrawal \\
\hline 299-E25-40 & $9 / 29 / 1989$ & & slug injection and withdrawal \\
\hline 299-E25-41 & $9 / 29 / 1989$ & & slug injection and withdrawal \\
\hline 299-E26-11 & $8 / 28 / 1990$ & & slug withdrawal \\
\hline 299-E26-9 & $8 / 13 / 1990$ & & slug withdrawal \\
\hline 299-E27-13 & $10 / 20 / 1989$ & & slug injection and withdrawal \\
\hline 299-E27-14 & $10 / 20 / 1989$ & & slug injection and withdrawal \\
\hline 299-E27-15 & $10 / 19 / 1989$ & & slug injection and withdrawal \\
\hline $299-E 32-5$ & $8 / 13 / 1990$ & & slug withdrawal \\
\hline 299-E33-33 & $9 / 27 / 1989$ & & slug injection and withdrawal \\
\hline 299-E33-334 & $2 / 1 / 2000$ & $a$ & slug withdrawal \\
\hline 299-E33-334 & $2 / 1 / 2000$ & $\bar{b}$ & slug withdrawal \\
\hline 299-E33-335 & $3 / 28 / 2000$ & $\bar{a}$ & slug withdrawal \\
\hline 299-E33-335 & $3 / 28 / 2000$ & $\mathrm{~b}$ & slug withdrawal \\
\hline $299-E 33-44$ & 10/13/1998 & $\bar{a}$ & slug withdrawal \\
\hline 299-E33-44 & $10 / 13 / 1998$ & $\bar{b}$ & slug withdrawal \\
\hline $299-E 34-7$ & $10 / 5 / 1989$ & & slug withdrawal \\
\hline 299-E35-2 & $8 / 13 / 1990$ & & slug withdrawal \\
\hline 299-W10-15 & $11 / 3 / 1989$ & & slug withdrawal \\
\hline 299-W10-16 & $10 / 30 / 1989$ & & slug injection and withdrawal \\
\hline 299-W10-17 & $1 / 15 / 1991$ & a & slug injection \\
\hline 299-W10-17 & $1 / 15 / 1991$ & $\bar{b}$ & slug withdrawal \\
\hline 299-W10-18 & $1 / 16 / 1991$ & & slug withdrawal \\
\hline 299-W10-23 & $1 / 8 / 1999$ & $a$ & slug withdrawal \\
\hline 299-W10-23 & $1 / 8 / 1999$ & $\bar{b}$ & slug withdrawal \\
\hline 299-W10-24 & $1 / 11 / 1999$ & $\bar{a}$ & slug withdrawal \\
\hline $299-W 10-24$ & $1 / 11 / 1999$ & $\bar{b}$ & slug withdrawal \\
\hline 299-W10-26 & $10 / 15 / 1998$ & $a$ & slug withdrawal \\
\hline 299-W10-26 & $10 / 15 / 1998$ & $\bar{b}$ & slug withdrawal \\
\hline 299-W14-13 & $10 / 14 / 1998$ & $\bar{a}$ & slug withdrawal \\
\hline 299-W14-13 & $10 / 14 / 1998$ & $\bar{b}$ & slug withdrawal \\
\hline 299-W14-14 & $1 / 11 / 1999$ & $\bar{a}$ & slug withdrawal \\
\hline 299-W14-14 & $1 / 11 / 1999$ & $\bar{b}$ & slug withdrawal \\
\hline 299-W15-19 & $10 / 30 / 1989$ & & slug injection and withdrawal \\
\hline 299-W15-20 & $11 / 3 / 1989$ & $a$ & slug withdrawal \\
\hline 299-W15-20 & $11 / 3 / 1989$ & $\bar{b}$ & slug withdrawal \\
\hline 299-W15-22 & $1 / 15 / 1991$ & $\bar{a}$ & slug injection \\
\hline 299-W15-22 & $1 / 15 / 1991$ & $\mathrm{~b}$ & slug withdrawal \\
\hline 299-W15-24 & $12 / 18 / 1989$ & & slug withdrawal \\
\hline 299-W15-40 & $10 / 14 / 1998$ & $\bar{a}$ & slug withdrawal \\
\hline 299-W15-40 & $10 / 14 / 1998$ & $\bar{b}$ & slug withdrawal \\
\hline 299-W15-41 & $3 / 29 / 2000$ & a & slug withdrawal \\
\hline 299-W15-41 & $3 / 29 / 2000$ & b & slug withdrawal \\
\hline 299-W18-25 & $12 / 12 / 1990$ & $\bar{a}$ & slug injection \\
\hline 299-W18-25 & $12 / 12 / 1990$ & $\mathrm{~b}$ & slug withdrawal \\
\hline 299-W18-26 & $11 / 22 / 1989$ & & slug withdrawal \\
\hline 299-W19-31 & $1 / 17 / 1991$ & $\bar{a}$ & slug injection \\
\hline 299-W19-31 & $1 / 17 / 1991$ & $\bar{b}$ & slug withdrawal \\
\hline 299-W19-32 & 1/14/1991 & $\bar{a}$ & slug injection \\
\hline 299-W19-32 & $1 / 14 / 1991$ & b & slug withdrawal \\
\hline
\end{tabular}

Table A.5 Slug Test Information 


\begin{tabular}{|c|c|c|c|}
\hline well name & test start date & sequence & slugging method (injection, withdrawal) \\
\hline 299-W19-41 & $10 / 19 / 1998$ & $a$ & slug withdrawal \\
\hline 299-W19-41 & 10/19/1998 & $\bar{b}$ & slug withdrawal \\
\hline 299-W19-42 & 10/15/1998 & a & slug withdrawal \\
\hline 299-W19-42 & $10 / 15 / 1998$ & $\mathrm{~b}$ & slug withdrawal \\
\hline $299-W 22-45$ & $1 / 27 / 2000$ & a & slug withdrawal \\
\hline 299-W22-45 & $1 / 27 / 2000$ & $\mathrm{~b}$ & slug withdrawal \\
\hline 299-W22-46 & $4 / 13 / 2000$ & a & slug withdrawal \\
\hline 299-W22-46 & $4 / 13 / 2000$ & b & slug withdrawal \\
\hline $299-W 22-48$ & $1 / 26 / 2000$ & $\mathbf{a}$ & slug withdrawal \\
\hline 299-W22-48 & $1 / 26 / 2000$ & b & slug withdrawal \\
\hline 299-W22-49 & $1 / 27 / 2000$ & $\bar{a}$ & slug withdrawal \\
\hline $299-W 22-49$ & $1 / 27 / 2000$ & $\mathrm{~b}$ & slug withdrawal \\
\hline $299-W 22-50$ & $4 / 10 / 2000$ & $\bar{a}$ & slug withdrawal \\
\hline $299-W 22-50$ & $4 / 10 / 2000$ & b & slug withdrawal \\
\hline 299-W22-79 & $10 / 19 / 1998$ & $\bar{a}$ & slug withdrawal \\
\hline 299-W22-79 & 10/19/1998 & b & slug withdrawal \\
\hline 299-W22-80 & $10 / 25 / 2000$ & $a$ & slug withdrawal \\
\hline $299-W 22-80$ & $10 / 25 / 2000$ & b & slug withdrawal \\
\hline 299-W22-81 & $4 / 30 / 2001$ & $\bar{a}$ & slug withdrawal \\
\hline 299-W22-81 & $4 / 30 / 2001$ & b & slug withdrawal \\
\hline 299-W22-82 & $4 / 25 / 2001$ & $\bar{a}$ & slug withdrawal \\
\hline 299-W22-82 & $4 / 25 / 2001$ & b & slug withdrawal \\
\hline $299-W 22-83$ & $4 / 26 / 2001$ & $\bar{a}$ & slug withdrawal \\
\hline 299-W22-83 & $4 / 26 / 2001$ & b & slug withdrawal \\
\hline 299-W22-84 & $12 / 4 / 2001$ & $\mathbf{a}$ & slug withdrawal \\
\hline $299-W 22-84$ & $12 / 4 / 2001$ & $\bar{b}$ & slug withdrawal \\
\hline $299-W 22-85$ & $12 / 5 / 2001$ & $\bar{a}$ & slug withdrawal \\
\hline 299-W22-85 & $12 / 5 / 2001$ & $\mathrm{~b}$ & slug withdrawal \\
\hline 299-W23-13 & $12 / 12 / 1990$ & & slug injection \\
\hline 299-W23-14 & $5 / 12 / 1991$ & $a$ & slug injection \\
\hline 299-W23-14 & $5 / 12 / 1991$ & $\bar{b}$ & slug withdrawal \\
\hline 299-W23-15 & $1 / 24 / 2000$ & $\bar{a}$ & slug withdrawal \\
\hline 299-W23-15 & $1 / 24 / 2000$ & $\bar{b}$ & slug withdrawal \\
\hline 299-W23-20 & $11 / 1 / 2000$ & $\mathrm{a}$ & slug withdrawal \\
\hline 299-W23-20 & $11 / 1 / 2000$ & $\mathrm{~b}$ & slug withdrawal \\
\hline 299-W23-21 & $1 / 30 / 2001$ & $a$ & slug withdrawal \\
\hline 299-W23-21 & $1 / 30 / 2001$ & $\bar{b}$ & slug withdrawal \\
\hline 299-W26-10 & $5 / 31 / 1990$ & & slug withdrawal \\
\hline 299-W26-11 & $5 / 31 / 1990$ & $\mathrm{a}$ & slug injection \\
\hline 299-W26-11 & $5 / 31 / 1990$ & $\bar{b}$ & slug withdrawal \\
\hline 299-W26-12 & $5 / 10 / 1990$ & $\bar{a}$ & slug injection \\
\hline 299-W26-12 & $5 / 10 / 1990$ & $\mathrm{~b}$ & slug withdrawal \\
\hline 299-W26-13 & $1 / 25 / 2000$ & $a$ & slug withdrawal \\
\hline 299-W26-13 & $1 / 25 / 2000$ & $\bar{b}$ & slug withdrawal \\
\hline 299-W26-8 & $5 / 31 / 1990$ & & slug withdrawal \\
\hline 299-W26-9 & $5 / 3 / 1990$ & & slug withdrawal \\
\hline 299-W7-7 & $12 / 5 / 1989$ & & slug withdrawal \\
\hline 299-W9-1 & $10 / 23 / 1987$ & $a$ & slug withdrawal \\
\hline 299-W9-1 & $10 / 23 / 1987$ & $\mathrm{~b}$ & slug withdrawal \\
\hline $699-40-39$ & $8 / 4 / 1989$ & & slug injection \\
\hline
\end{tabular}




\begin{tabular}{|c|c|c|c|}
\hline well name & test start date & sequence & slugging method (injection, withdrawal) \\
\hline $699-41-40$ & $7 / 7 / 1989$ & & slug injection \\
\hline 699-42-42B & $5 / 26 / 1993$ & a & pneumatic \\
\hline 699-42-42B & $5 / 26 / 1993$ & b & pneumatic \\
\hline 699-43-41E & $6 / 29 / 1989$ & & slug injection \\
\hline 699-43-41F & $5 / 30 / 1989$ & & slug injection \\
\hline $699-43-44$ & $1 / 28 / 2000$ & $\mathbf{a}$ & slug withdrawal \\
\hline $699-43-44$ & $1 / 28 / 2000$ & $\bar{b}$ & slug withdrawal \\
\hline 699-44-43B & $5 / 19 / 1989$ & $\mathbf{a}$ & slug injection \\
\hline 699-44-43B & $5 / 19 / 1989$ & $\bar{b}$ & slug withdrawal \\
\hline 699-44-43B & $5 / 19 / 1989$ & c & slug injection \\
\hline 699-44-43B & $5 / 19 / 1989$ & $\mathrm{~d}$ & slug withdrawal \\
\hline 699-44-43B & $7 / 5 / 1989$ & $\mathbf{a}$ & slug injection \\
\hline 699-44-43B & $7 / 5 / 1989$ & $\bar{b}$ & slug injection \\
\hline 699-S22-E9A & $1 / 2 / 1992$ & & slug withdrawal \\
\hline 699-S22-E9D & $4 / 14 / 1992$ & & slug injection and withdrawal \\
\hline 699-S27-E9A & $1 / 2 / 1992$ & & slug withdrawal \\
\hline 699-S30-E10A & $1 / 29 / 1990$ & a & slug withdrawal \\
\hline 699-S30-E10A & $1 / 29 / 1990$ & b & slug withdrawal \\
\hline 699-S30-E10B & $2 / 2 / 1990$ & $\mathbf{a}$ & slug withdrawal \\
\hline 699-S30-E10B & $2 / 2 / 1990$ & $\bar{b}$ & slug withdrawal \\
\hline 699-S31-E10A & $2 / 14 / 1990$ & $\bar{a}$ & slug withdrawal \\
\hline 699-S31-E10A & $2 / 14 / 1990$ & b & slug withdrawal \\
\hline 699-S31-E10C & $1 / 29 / 1990$ & & slug withdrawal \\
\hline 699-S31-E10D & $1 / 24 / 1990$ & $\mathrm{a}$ & slug withdrawal \\
\hline 699-S31-E10D & $1 / 24 / 1990$ & b & slug withdrawal \\
\hline 699-S31-E8A & $1 / 22 / 1990$ & $\bar{a}$ & slug withdrawal \\
\hline 699-S31-E8A & $1 / 22 / 1990$ & $\bar{b}$ & slug withdrawal \\
\hline 699-S32-E8 & $2 / 12 / 1990$ & & slug withdrawal \\
\hline 699-S34-E10 & $2 / 8 / 1990$ & a & slug withdrawal \\
\hline 699-S34-E10 & $2 / 8 / 1990$ & b & slug withdrawal \\
\hline 699-S37-E11 & $2 / 2 / 1990$ & $\mathrm{a}$ & slug withdrawal \\
\hline 699-S37-E11 & $2 / 2 / 1990$ & $\bar{b}$ & slug withdrawal \\
\hline 699-S38-E11 & $2 / 2 / 1990$ & $\bar{c}$ & slug withdrawal \\
\hline 699-S38-E12A & $2 \pi / 1990$ & & slug withdrawal \\
\hline 699-S38-E12B & $2 \pi / 1990$ & & slug withdrawal \\
\hline 699-S41-E11A & $2 / 1 / 1990$ & & slug withdrawal \\
\hline 699-S41-E12 & $2 / 28 / 1990$ & a & slug withdrawal \\
\hline 699-S41-E12 & $2 / 28 / 1990$ & $\mathrm{~b}$ & slug withdrawal \\
\hline 699-S41-E13C & $2 / 8 / 1990$ & & slug withdrawal \\
\hline
\end{tabular}




\begin{tabular}{|c|c|c|c|c|c|c|c|c|c|}
\hline well name & $\begin{array}{c}\text { test start } \\
\text { date }\end{array}$ & sequence & $\begin{array}{c}\text { number of } \\
\text { observation } \\
\text { wells }\end{array}$ & $\begin{array}{c}\text { observation well \#1 } \\
\text { well name }\end{array}$ & $\begin{array}{l}\text { distance from } \\
\text { stress well [m] }\end{array}$ & $\begin{array}{l}\text { reference point } \\
\text { elevation [m] }\end{array}$ & $\begin{array}{l}\text { reference } \\
\text { datum } \\
\text { (ground } \\
\text { surface, top } \\
\text { of casing. } \\
\text { brass cap. } \\
\text { etc.) }\end{array}$ & $\begin{array}{l}\text { observation } \\
\text { well open } \\
\text { interval, top } \\
\text { depth below } \\
\text { ref point [m] }\end{array}$ & $\begin{array}{c}\text { observation } \\
\text { well open } \\
\text { interval, } \\
\text { bottom depth } \\
\text { below ref } \\
\text { point [m] }\end{array}$ \\
\hline $199-\mathrm{N}-32$ & $3 / 26 / 1984$ & & 1 & $199-\mathrm{N}-33$ & 157 & & & & \\
\hline 299-E27-10 & $8 / 11 / 1987$ & & 1 & 299-E26-1 & 85.3 & & & 66.14 & 69.19 \\
\hline 299-E34-2 & $8 / 7 / 1987$ & $a$ & 1 & 299-E32-1 & 18.3 & & & 65.53 & 70.1 \\
\hline 299-E34-2 & $8 / 7 / 1987$ & $b$ & 1 & 299-E32-1 & 18.3 & & & 65.53 & 70.1 \\
\hline $299-W 7-1$ & $7 / 15 / 1987$ & $\bar{a}$ & 1 & $299-W 8-1$ & 182.6 & & & & \\
\hline 299-W7-1 & $7 / 15 / 1987$ & $\mathrm{~b}$ & 1 & 299-W8-1 & 182.6 & & & & \\
\hline 299-W/7-2 & 9/16/1987 & a & 1 & 299-W7-3 & 10.7 & & & & \\
\hline 299-W7-2 & $9 / 16 / 1987$ & $\mathrm{~b}$ & 1 & $299-W 7-3$ & 10.7 & & & & \\
\hline 299-W10-13 & 9/14/1987 & & 1 & 299-W10-14 & 10.4 & & & 73.2 & \\
\hline 299-W10-14 & 10/26/1987 & & 1 & $299-W 10-13$ & 10.4 & & & 69.19 & 75.29 \\
\hline 299-W10-24 & $4 / 21 / 1999$ & & 1 & $299-W 11-27$ & 2.27 & & & & \\
\hline 299-W10-26 & $4 / 24 / 1999$ & & 1 & 299-W10-18 & 5.53 & & & & \\
\hline 299-W14-13 & $4 / 1 / 1999$ & & 1 & 299-W14-12 & 4.36 & & & & \\
\hline 299-W15-16 & $8 / 20 / 1987$ & $\mathrm{a}$ & 1 & 299-W15-17 & 14.6 & & & 67.1 & \\
\hline 299-W15-16 & $8 / 20 / 1987$ & $\mathrm{~b}$ & 1 & 299-W15-17 & 14.6 & & & 67.1 & \\
\hline 299-W15-18 & $7 / 21 / 1987$ & & 1 & $299-W 18-4$ & $\sim 122$ & & & 61 & 74.3 \\
\hline 299-W18-21 & $7 / 14 / 1987$ & $\mathrm{a}$ & 1 & 299-W18-22 & 14.6 & & & 62.5 & \\
\hline 299-W18-21 & $7 / 14 / 1987$ & $\bar{b}$ & 1 & 299-W18-22 & 14.6 & & & 62.5 & \\
\hline 299-W18-22 & $8 / 26 / 1987$ & & 1 & 299-W18-21 & 14.6 & & & 60.24 & 69.39 \\
\hline 299-W19-42 & $3 / 26 / 1999$ & & 1 & 299-W19-31 & 4.59 & & & & \\
\hline $299-W / 22-49$ & $4 / 20 / 2000$ & & 1 & 299-W22-39 & 12.1 & & & & \\
\hline 699-S22-E9D & $4 / 14 / 1992$ & & 1 & 699-S22-E9A & 9.1 & & & 7.8 & 12.37 \\
\hline $299-\mathrm{E} 18-3$ & $8 / 12 / 1988$ & $\mathrm{a}$ & 2 & 299-E 18-2 & 39.0 & & & 95.1 & 101.38 \\
\hline 299-E18-3 & $8 / 12 / 1988$ & $\mathrm{~b}$ & 2 & 299-E18-2 & 39.0 & & & 95.1 & 101.38 \\
\hline 299-W18-24 & $7 / 17 / 1987$ & & 2 & 299-W18-2 & 38.1 & & & 62.48 & 77.72 \\
\hline $399-1-17 \mathrm{~B}$ & $2 / 9 / 1987$ & $\mathrm{a}$ & 2 & $399-1-17 \mathrm{~A}$ & 8.99 & & & 7.62 & 12.19 \\
\hline $399-1-17 \mathrm{~B}$ & $2 / 9 / 1987$ & $\mathrm{~b}$ & 2 & $399-1-17 \mathrm{~A}$ & 8.99 & & & 7.62 & 12.19 \\
\hline 399-1-17B & $2 / 9 / 1987$ & C & 2 & 399-1-17A & 8.99 & & & 7.62 & 12.19 \\
\hline $399-1-17 \mathrm{C}$ & $2 / 11 / 1987$ & $\mathrm{a}$ & 2 & 399-1-17A & 9.72 & & & 7.62 & 12.19 \\
\hline $399-1-17 \mathrm{C}$ & $2 / 11 / 1987$ & $\mathrm{~b}$ & 2 & 399-1-17A & 9.72 & & & 7.62 & 12.19 \\
\hline $399-1-17 \mathrm{C}$ & $2 / 11 / 1987$ & C & 2 & 399-1-17A & 9.72 & & & 7.62 & 12.19 \\
\hline 399-1-18B & $1 / 29 / 1987$ & $a$ & 2 & 399-1-18A & & & & & \\
\hline 399-1-18B & $1 / 29 / 1987$ & $\mathrm{~b}$ & 2 & 399-1-18A & & & & & \\
\hline $399-1-18 \mathrm{C}$ & \begin{tabular}{|l|}
$2 / 3 / 1987$ \\
\end{tabular} & $a$ & 2 & 399-1-18A & & & & & \\
\hline $399-1-18 \mathrm{C}$ & $2 / 3 / 1987$ & $\mathrm{~b}$ & 2 & 399-1-18A & & & & & \\
\hline $399-1-18 \mathrm{C}$ & $2 / 3 / 1987$ & C & 2 & 399-1-18A & & & & & \\
\hline $399-1-9$ & $3 / 2 / 1987$ & & 3 & $399-1-3$ & 4.0 & & & & \\
\hline 399-1-16A & $2 / 26 / 1987$ & $\mathrm{a}$ & 3 & $399-1-16 \mathrm{~B}$ & 7.04 & & & 32 & 35.05 \\
\hline $399-1-16 \mathrm{~A}$ & $2 / 26 / 1987$ & $b$ & 3 & 399-1-16B & 7.04 & & & 32 & 35.05 \\
\hline $399-1-16 \mathrm{~A}$ & $2 / 26 / 1987$ & C & 3 & $399-1-16 \mathrm{~B}$ & 7.04 & & & 32 & 35.05 \\
\hline $399-1-16 \mathrm{~B}$ & $2 / 19 / 1987$ & $a$ & 3 & 399-1-16A & 7.04 & & & 9.75 & 14.33 \\
\hline 399-1-16B & $2 / 19 / 1987$ & $b$ & 3 & 399-1-16A & 7.04 & & & 9.75 & 14.33 \\
\hline $399-1-16 \mathrm{~B}$ & $2 / 24 / 1987$ & $a$ & 3 & $399-1-16 \mathrm{~A}$ & 7.04 & & & 9.75 & 14.33 \\
\hline $399-1-16 \mathrm{~B}$ & $2 / 24 / 1987$ & $\mathrm{~b}$ & 3 & 399-1-16A & 7.04 & & & 9.75 & 14.33 \\
\hline $399-1-16 \mathrm{C}$ & $2 / 17 / 1987$ & $a$ & 3 & 399-1-16A & 7.19 & & & 9.75 & 14.33 \\
\hline $399-1-16 \mathrm{C}$ & $2 / 17 / 1987$ & $\mathrm{~b}$ & 3 & 399-1-16A & 7.19 & & & 9.75 & 14.33 \\
\hline $399-1-16 \mathrm{C}$ & $2 / 17 / 1987$ & c & 3 & 399-1-16A & 7.19 & & & 9.75 & 14.33 \\
\hline 699-42-42B & $5 / 26 / 1993$ & $a$ & 3 & 699-43-42K (zone 3 & 11.09 & & & 56.11 & 58.23 \\
\hline $699-42-42 \mathrm{~B}$ & $5 / 26 / 1993$ & $\mathrm{~b}$ & 3 & 699-43-42K (zone 3 & 11.09 & & & 56.11 & 58.23 \\
\hline 699-42-42B & $6 / 1 / 1993$ & & 3 & 699-43-42K (zone 3 ) & 11.09 & & & 56.11 & 58.23 \\
\hline
\end{tabular}

Table A.6 First Observation Well Information and Results 


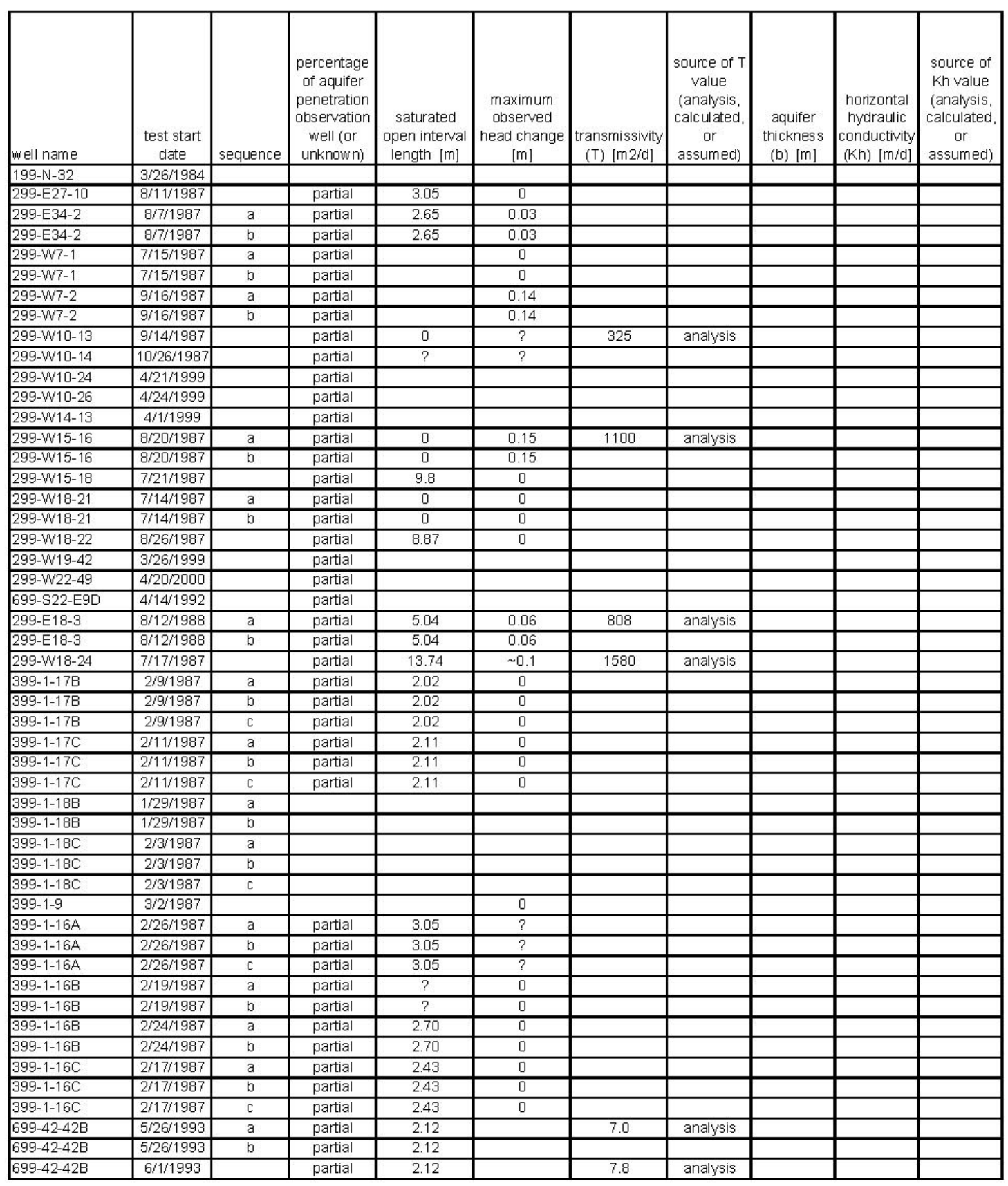




\begin{tabular}{|c|c|c|c|c|c|c|c|c|c|c|}
\hline well name & $\begin{array}{c}\text { test start } \\
\text { date }\end{array}$ & sequence & $\begin{array}{c}\text { vertical } \\
\text { anisotropy } \\
\text { KV/Kh } \\
\text { [dimension } \\
\text { less] }\end{array}$ & $\begin{array}{c}\text { source of } \\
\text { KV/Kh } \\
\text { (analysis, } \\
\text { calculated, } \\
\text { or } \\
\text { assumed) } \\
\end{array}$ & $\begin{array}{c}\text { specific } \\
\text { yield (Sy) } \\
\text { [dimension } \\
\text { less] }\end{array}$ & $\begin{array}{c}\text { source of } \\
\text { Sy } \\
\text { (analysis, } \\
\text { calculated, } \\
\text { or } \\
\text { assumed) }\end{array}$ & $\begin{array}{c}\text { storativity } \\
(S) \\
\text { [dimension } \\
\text { less] }\end{array}$ & $\begin{array}{l}\text { source of S } \\
\text { (analysis, } \\
\text { calculated, } \\
\text { or } \\
\text { assumed) }\end{array}$ & $\begin{array}{c}\text { effective } \\
\text { porosity } \\
\text { (ne) } \\
\text { [dimension } \\
\text { less] }\end{array}$ & $\begin{array}{l}\text { source of } n \\
\text { (analysis, } \\
\text { calculated, } \\
\text { or } \\
\text { assumed) }\end{array}$ \\
\hline $199-N-32$ & $3 / 26 / 1984$ & & & & & & & & & \\
\hline 299-E27-10 & $8 / 11 / 1987$ & & & & & & & & & \\
\hline 299-E34-2 & $8 / 7 / 1987$ & $\mathrm{a}$ & & & & & & & & \\
\hline 299-E34-2 & $8 / 7 / 1987$ & $\mathrm{~b}$ & & & & & & & & \\
\hline 299-W7-1 & $7 / 15 / 1987$ & $\mathrm{a}$ & & & & & & & & \\
\hline 299-W/7-1 & $7 / 15 / 1987$ & $\mathrm{~b}$ & & & & & & & & \\
\hline 299-W7-2 & $9 / 16 / 1987$ & $a$ & & & & & & & & \\
\hline 299-W7-2 & $9 / 16 / 1987$ & $\mathrm{~b}$ & & & & & & & & \\
\hline 299-W10-13 & $9 / 14 / 1987$ & & & & & & 0.009 & analysis & & \\
\hline 299-W10-14 & $10 / 26 / 1987$ & & & & & & & & & \\
\hline 299-W10-24 & $4 / 21 / 1999$ & & & & & & & & & \\
\hline 299-W10-26 & $4 / 24 / 1999$ & & & & & & & & & \\
\hline 299-W14-13 & $4 / 1 / 1999$ & & & & & & & & & \\
\hline 299-W15-16 & $8 / 20 / 1987$ & $a$ & & & & & 0.027 & analysis & & \\
\hline 299-W15-16 & $8 / 20 / 1987$ & $\mathrm{~b}$ & & & & & & & & \\
\hline 299-W15-18 & $7 / 21 / 1987$ & & & & & & & & & \\
\hline 299-W18-21 & $7 / 14 / 1987$ & $a$ & & & & & & & & \\
\hline 299-W18-21 & $7 / 14 / 1987$ & $\mathrm{~b}$ & & & & & & & & \\
\hline 299-W18-22 & $8 / 26 / 1987$ & & & & & & & & & \\
\hline 299-W19-42 & $3 / 26 / 1999$ & & & & & & & & & \\
\hline 299-W22-49 & $4 / 20 / 2000$ & & & & & & & & & \\
\hline 699-S22-E9D & $4 / 14 / 1992$ & & & & & & & & & \\
\hline 299-E18-3 & $8 / 12 / 1988$ & a & & & & & 0.01 & analysis & & \\
\hline $299-E 18-3$ & $8 / 12 / 1988$ & $\mathrm{~b}$ & & & & & & & & \\
\hline 299-W18-24 & $7 / 17 / 1987$ & & & & & & 0.001 & analysis & & \\
\hline $399-1-17 \mathrm{~B}$ & $2 / 9 / 1987$ & $a$ & & & & & & & & \\
\hline 399-1-17B & $2 / 9 / 1987$ & $\mathrm{~b}$ & & & & & & & & \\
\hline 399-1-17B & $2 / 9 / 1987$ & C & & & & & & & & \\
\hline $399-1-17 \mathrm{C}$ & $2 / 11 / 1987$ & $a$ & & & & & & & & \\
\hline $399-1-17 \mathrm{C}$ & $2 / 11 / 1987$ & $b$ & & & & & & & & \\
\hline $399-1-17 \mathrm{C}$ & $2 / 11 / 1987$ & $\mathrm{c}$ & & & & & & & & \\
\hline 399-1-18B & $1 / 29 / 1987$ & $\mathrm{a}$ & & & & & & & & \\
\hline 399-1-18B & $1 / 29 / 1987$ & $\mathrm{~b}$ & & & & & & & & \\
\hline 399-1-18C & $2 / 3 / 1987$ & a & & & & & & & & \\
\hline 399-1-18C & $2 / 3 / 1987$ & $b$ & & & & & & & & \\
\hline $399-1-18 \mathrm{C}$ & $2 / 3 / 1987$ & $\mathrm{C}$ & & & & & & & & \\
\hline $399-1-9$ & $3 / 2 / 1987$ & & & & & & & & & \\
\hline 399-1-16A & $2 / 26 / 1987$ & a & & & & & & & & \\
\hline $399-1-16 \mathrm{~A}$ & $2 / 26 / 1987$ & $\mathrm{~b}$ & & & & & & & & \\
\hline 399-1-16A & $2 / 26 / 1987$ & C & & & & & & & & \\
\hline 399-1-16B & $2 / 19 / 1987$ & $a$ & & & & & & & & \\
\hline 399-1-16B & $2 / 19 / 1987$ & $\mathrm{~b}$ & & & & & & & & \\
\hline 399-1-16B & $2 / 24 / 1987$ & $a$ & & & & & & & & \\
\hline 399-1-16B & $2 / 24 / 1987$ & $\mathrm{~b}$ & & & & & & & & \\
\hline $399-1-16 \mathrm{C}$ & $2 / 17 / 1987$ & $\mathrm{a}$ & & & & & & & & \\
\hline $399-1-16 \mathrm{C}$ & $2 / 17 / 1987$ & $\mathrm{~b}$ & & & & & & & & \\
\hline $399-1-16 \mathrm{C}$ & $2 / 17 / 1987$ & C & & & & & & & & \\
\hline 699-42-42B & $5 / 26 / 1993$ & $a$ & 0.40 & assumed & & 0.00 & $00016-0.00$ & assumed & & \\
\hline 699-42-42B & $5 / 26 / 1993$ & $\mathrm{~b}$ & & & & & & & & \\
\hline 699-42-42B & $6 / 1 / 1993$ & & 0.45 & assumed & & & 0.00005 & assumed & & \\
\hline
\end{tabular}




\begin{tabular}{|c|c|c|c|c|c|c|c|c|c|}
\hline well name & $\begin{array}{c}\text { test start } \\
\text { date }\end{array}$ & sequence & $\begin{array}{c}\text { number of } \\
\text { observation } \\
\text { wells }\end{array}$ & $\begin{array}{c}\text { observation well \#2 } \\
\text { well name }\end{array}$ & $\begin{array}{l}\text { distance from } \\
\text { stress well [m] }\end{array}$ & $\begin{array}{c} \\
\text { reference } \\
\text { point } \\
\text { elevation } \\
\text { [m] }\end{array}$ & $\begin{array}{l}\text { reference } \\
\text { datum } \\
\text { (ground } \\
\text { surface, top } \\
\text { of casing, } \\
\text { brass cap, } \\
\text { etc.) }\end{array}$ & $\begin{array}{l}\text { observation well } \\
\text { open interval, } \\
\text { top depth below } \\
\text { ref point [m] }\end{array}$ & $\begin{array}{c}\text { observation well } \\
\text { open interval, } \\
\text { bottom depth } \\
\text { below ref point } \\
\text { [m] }\end{array}$ \\
\hline 699-S22-E9D & 4/14/1992 & & 1 & & & & & & \\
\hline 299-E18-3 & $8 / 12 / 1988$ & $\mathrm{a}$ & 2 & 299-E18-4 & 18.6 & & & 94.82 & 101.07 \\
\hline 299-E18-3 & $8 / 2 / 1988$ & $\mathrm{~b}$ & 2 & 299-E18-4 & 18.6 & & & 94.82 & 101.07 \\
\hline 299-W18-24 & $7 / 17 / 1987$ & & 2 & 299-W15-18 & 224.0 & & & 70.77 & 73.82 \\
\hline 399-1-17B & $2 / 9 / 1987$ & $\bar{a}$ & 2 & $399-1-17 \mathrm{C}$ & 8.53 & & & 49.07 & 52.12 \\
\hline 399-1-17B & $2 / 9 / 1987$ & $\mathrm{~b}$ & 2 & $399-1-17 \mathrm{C}$ & 8.53 & & & 49.07 & 52.12 \\
\hline 399-1-17B & \begin{tabular}{|l|}
$2 / 9 / 1987$ \\
\end{tabular} & C & 2 & $399-1-17 \mathrm{C}$ & 8.53 & & & 49.07 & 52.12 \\
\hline $399-1-17 \mathrm{C}$ & \begin{tabular}{|l|}
$2 / 11 / 1987$ \\
\end{tabular} & $\mathrm{a}$ & 2 & 399-1-17B & 8.53 & & & 30.48 & 33.53 \\
\hline $399-1-17 \mathrm{C}$ & \begin{tabular}{|l|}
$2 / 11 / 1987$ \\
\end{tabular} & $b$ & 2 & 399-1-17B & 8.53 & & & 30.48 & 33.53 \\
\hline $399-1-17 \mathrm{C}$ & $2 / 11 / 1987$ & C & 2 & 399-1-17B & 8.53 & & & 30.48 & 33.53 \\
\hline 399-1-18B & \begin{tabular}{|l|}
$1 / 29 / 1987$ \\
\end{tabular} & $a$ & 2 & $399-1-18 \mathrm{C}$ & & & & & \\
\hline 399-1-18B & $1 / 29 / 1987$ & $\mathrm{~b}$ & 2 & $399-1-18 C$ & & & & & \\
\hline 399-1-18C & $2 / 3 / 1987$ & $a$ & 2 & 399-1-18B & & & & & \\
\hline $399-1-18 \mathrm{C}$ & \begin{tabular}{|l|}
$2 / 3 / 1987$ \\
\end{tabular} & $b$ & 2 & 399-1-18B & & & & & \\
\hline $399-1-18 \mathrm{C}$ & \begin{tabular}{|l|}
$2 / 3 / 1987$ \\
\end{tabular} & $\mathrm{C}$ & 2 & 399-1-18B & & & & & \\
\hline $399-1-9$ & \begin{tabular}{|l|}
$3 / 2 / 1987$ \\
\end{tabular} & & 3 & $399-1-7$ & 7.3 & & & & \\
\hline 399-1-16A & $2 / 26 / 1987$ & $\mathrm{a}$ & 3 & $399-1-16 \mathrm{C}$ & 7.19 & & & 50.9 & 54.1 \\
\hline 399-1-16A & $2 / 26 / 1987$ & $\mathrm{~b}$ & 3 & $399-1-16 \mathrm{C}$ & 7.19 & & & 50.9 & 54.1 \\
\hline 399-1-16A & $2 / 26 / 1987$ & $\mathrm{c}$ & 3 & $399-1-16 \mathrm{C}$ & 7.19 & & & 50.9 & 54.1 \\
\hline 399-1-16B & 2/19/1987 & $\bar{a}$ & 3 & $399-1-16 \mathrm{C}$ & 12.77 & & & 50.9 & 54.1 \\
\hline 399-1-16B & $2 / 19 / 1987$ & $\mathrm{~b}$ & 3 & $399-1-16 \mathrm{C}$ & 12.77 & & & 50.9 & 54.1 \\
\hline 399-1-16B & $2 / 24 / 1987$ & $\bar{a}$ & $\overline{3}$ & $399-1-16 \mathrm{C}$ & 12.77 & & & 50.9 & 54.1 \\
\hline 399-1-16B & $2 / 24 / 1987$ & $\bar{b}$ & $\overline{3}$ & $399-1-16 \mathrm{C}$ & 12.77 & & & 50.9 & 54.1 \\
\hline 399-1-16C & $2 / 17 / 1987$ & $\mathrm{a}$ & 3 & $399-1-16 \mathrm{~B}$ & 12.77 & & & 32 & 35.05 \\
\hline $399-1-16 \mathrm{C}$ & \begin{tabular}{|l|}
$2 / 17 / 1987$ \\
\end{tabular} & $\mathrm{~b}$ & 3 & $399-1-16 \mathrm{~B}$ & 12.77 & & & 32 & 35.05 \\
\hline $399-1-16 \mathrm{C}$ & $2 / 17 / 1987$ & $\mathrm{c}$ & 3 & $399-1-16 \mathrm{~B}$ & 12.77 & & & 32 & 35.05 \\
\hline 699-42-42B & $5 / 26 / 1993$ & $\bar{a}$ & 3 & 699-43-42K (zone 4) & 11.09 & & & 60.37 & 62.2 \\
\hline $699-42-42 B$ & $5 / 26 / 1993$ & $\mathrm{~b}$ & 3 & 699-43-42K (zone 4) & 11.09 & & & 60.37 & 62.2 \\
\hline 699-42-42B & $6 / 1 / 1993$ & & 3 & 699-43-42K (zone 4) & 11.09 & & & 60.37 & 62.2 \\
\hline
\end{tabular}

Table A.7 Second Observation Well Information and Results 


\begin{tabular}{|c|c|c|c|c|c|c|c|c|c|c|c|}
\hline well name & $\begin{array}{c}\text { test start } \\
\text { date }\end{array}$ & sequence & $\begin{array}{c}\text { percentage } \\
\text { of aquifer } \\
\text { penetration } \\
\text { observation } \\
\text { well (or } \\
\text { unknown) }\end{array}$ & $\begin{array}{l}\text { saturated } \\
\text { open } \\
\text { interval } \\
\text { length [m] }\end{array}$ & $\begin{array}{c}\text { maximum } \\
\text { observed } \\
\text { head } \\
\text { change }[\mathrm{m}]\end{array}$ & \begin{tabular}{|c|} 
\\
transmissivi \\
ty (T) \\
{$[\mathrm{m} 2 / \mathrm{d}]$}
\end{tabular} & $\begin{array}{l}\text { source of } \mathrm{T} \\
\text { value } \\
\text { (analysis, } \\
\text { calculated, } \\
\text { or } \\
\text { assumed) }\end{array}$ & $\begin{array}{l}\text { aquifer } \\
\text { thickness } \\
\text { (b) [m] }\end{array}$ & $\begin{array}{l}\text { horizontal } \\
\text { hydraulic } \\
\text { conductivity } \\
\text { (Kh) [m/d] }\end{array}$ & $\begin{array}{c}\text { source of } \\
\text { Kh value } \\
\text { (analysis, } \\
\text { calculated, } \\
\text { or } \\
\text { assumed) }\end{array}$ & $\begin{array}{c}\text { vertical } \\
\text { anisotropy } \\
\text { Kv/Kh } \\
\text { [dimensio } \\
\text { nless] }\end{array}$ \\
\hline 699-S22-E9D & 4/14/1992 & & & & & & & & & & \\
\hline 299-E18-3 & $8 / 12 / 1988$ & a & partial & 5.24 & 0.02 & 808 & analysis & & & & \\
\hline 299-E18-3 & $8 / 12 / 1988$ & b & partial & 5.24 & 0.02 & & & & & & \\
\hline 299-W18-24 & $7 / 17 / 1987$ & & partial & 3.05 & $?$ & 1580 & analysis & & & & \\
\hline 399-1-17B & $2 / 9 / 1987$ & a & full & 3.05 & 0 & & & & & & \\
\hline 399-1-17B & $2 / 9 / 1987$ & $\mathrm{~b}$ & full & 3.05 & 0 & & & & & & \\
\hline 399-1-17B & $2 / 9 / 1987$ & C & full & 3.05 & 0 & & & & & & \\
\hline $399-1-17 \mathrm{C}$ & $2 / 11 / 1987$ & $\mathrm{a}$ & partial & 3.05 & 0 & & & & & & \\
\hline $399-1-17 \mathrm{C}$ & $2 / 11 / 1987$ & $b$ & partial & 3.05 & 0 & & & & & & \\
\hline $399-1-17 C$ & $2 / 11 / 1987$ & $\mathrm{C}$ & partial & 3.05 & 0 & & & & & & \\
\hline 399-1-18B & $1 / 29 / 1987$ & a & & & & & & & & & \\
\hline 399-1-18B & $1 / 29 / 1987$ & $b$ & & & & & & & & & \\
\hline $399-1-18 \mathrm{C}$ & $2 / 3 / 1987$ & a & & & & & & & & & \\
\hline $399-1-18 \mathrm{C}$ & $2 / 3 / 1987$ & $\mathrm{~b}$ & & & & & & & & & \\
\hline $399-1-18 \mathrm{C}$ & \begin{tabular}{|l|}
$2 / 3 / 1987$ \\
\end{tabular} & c & & & & & & & & & \\
\hline $399-1-9$ & $3 / 2 / 1987$ & & & & 0 & & & & & & \\
\hline 399-1-16A & $2 / 26 / 1987$ & $a$ & & 3.2 & & & & & & & \\
\hline $399-1-16 \mathrm{~A}$ & $2 / 26 / 1987$ & $b$ & & 3.2 & & & & & & & \\
\hline 399-1-16A & $2 / 26 / 1987$ & $\mathrm{C}$ & & 3.2 & & & & & & & \\
\hline $399-1-16 \mathrm{~B}$ & $2 / 19 / 1987$ & a & & 3.2 & 0 & & & & & & \\
\hline $399-1-16 \mathrm{~B}$ & $2 / 19 / 1987$ & $b$ & & 3.2 & 0 & & & & & & \\
\hline $399-1-16 \mathrm{~B}$ & $2 / 24 / 1987$ & $\bar{a}$ & & 3.2 & 0 & & & & & & \\
\hline $399-1-16 \mathrm{~B}$ & $2 / 24 / 1987$ & $b$ & & 3.2 & 0 & & & & & & \\
\hline $399-1-16 \mathrm{C}$ & $2 / 17 / 1987$ & 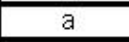 & partial & 3.05 & 0 & & & & & & \\
\hline $399-1-16 \mathrm{C}$ & $2 / 17 / 1987$ & $\mathrm{~b}$ & partial & 3.05 & 0 & & & & & & \\
\hline $399-1-16 \mathrm{C}$ & $2 / 17 / 1987$ & C & partial & 3.05 & 0 & & & & & & \\
\hline 699-42-42B & $5 / 26 / 1993$ & $\bar{a}$ & partial & 1.83 & & 7.8 & analysis & & & & 0.33 \\
\hline 699-42-42B & $5 / 26 / 1993$ & $b$ & partial & 1.83 & & & & & & & \\
\hline 699-42-42B & $6 / 1 / 1993$ & & partial & 1.83 & & 5.8 & analysis & & & & 0.45 \\
\hline
\end{tabular}




\begin{tabular}{|c|c|c|c|c|c|c|c|c|c|}
\hline well name & $\begin{array}{c}\text { test start } \\
\text { date }\end{array}$ & sequence & $\begin{array}{c}\text { source of } \\
\text { KV/Kh } \\
\text { (analysis, } \\
\text { calculated, } \\
\text { or } \\
\text { assumed) }\end{array}$ & $\begin{array}{c}\text { specific } \\
\text { yield (Sy) } \\
\text { [dimensio } \\
\text { nless] }\end{array}$ & $\begin{array}{c}\text { source of } \\
\text { Sy } \\
\text { (analysis, } \\
\text { calculated, } \\
\text { or } \\
\text { assumed) }\end{array}$ & $\begin{array}{c}\text { storativity } \\
\text { (S) } \\
\text { [dimensio } \\
\text { nless] }\end{array}$ & $\begin{array}{c}\text { source of } \mathrm{S} \\
\text { (analysis, } \\
\text { calculated, } \\
\text { or } \\
\text { assumed) }\end{array}$ & $\begin{array}{c}\text { effective } \\
\text { porosity } \\
\text { (ne) } \\
\text { [dimensio } \\
\text { nless] }\end{array}$ & $\begin{array}{c}\text { source of } \\
\text { ne } \\
\text { (analysis, } \\
\text { calculated, } \\
\text { or } \\
\text { assumed) }\end{array}$ \\
\hline 699-S22-E9D & 4/14/1992 & & & & & & & & \\
\hline 299-E18-3 & $8 / 2 / 1988$ & $\mathrm{a}$ & & & & 0.01 & analysis & & \\
\hline 299-E18-3 & 812/1988 & $\mathrm{b}$ & & & & & & & \\
\hline $299-W 18-24$ & 7/17/1987 & & & & & 0.001 & analysis & & \\
\hline 399-1-17B & \begin{tabular}{|l|}
$2 / 9 / 1987$ \\
\end{tabular} & $a$ & & & & & & & \\
\hline 399-1-17B & $2 / 9 / 1987$ & $\mathrm{~b}$ & & & & & & & \\
\hline $399-1-17 \mathrm{~B}$ & 2/9/1987 & C & & & & & & & \\
\hline $399-1-17 \mathrm{C}$ & $2 / 11 / 1987$ & a & & & & & & & \\
\hline $399-1-17 \mathrm{C}$ & $2 / 11 / 1987$ & $\mathrm{~b}$ & & & & & & & \\
\hline $399-1-17 \mathrm{C}$ & $2 / 11 / 1987$ & $\mathrm{C}$ & & & & & & & \\
\hline 399-1-18B & 1/29/1987 & $a$ & & & & & & & \\
\hline 399-1-18B & $1 / 29 / 1987$ & $\mathrm{~b}$ & & & & & & & \\
\hline $399-1-18 \mathrm{C}$ & 2/3/1987 & a & & & & & & & \\
\hline $399-1-18 \mathrm{C}$ & $2 / 3 / 1987$ & $\mathrm{~b}$ & & & & & & & \\
\hline $399-1-18 \mathrm{C}$ & $2 / 3 / 1987$ & C & & & & & & & \\
\hline $399-1-9$ & $3 / 2 / 1987$ & & & & & & & & \\
\hline 399-1-16A & $2 / 26 / 1987$ & $\mathrm{a}$ & & & & & & & \\
\hline 399-1-16A & $2 / 26 / 1987$ & $b$ & & & & & & & \\
\hline 399-1-16A & $2 / 26 / 1987$ & c & & & & & & & \\
\hline 399-1-16B & $2 / 19 / 1987$ & $a$ & & & & & & & \\
\hline 399-1-16B & $2 / 19 / 1987$ & $\mathrm{~b}$ & & & & & & & \\
\hline $399-1-16 \mathrm{~B}$ & $2 / 24 / 1987$ & $a$ & & & & & & & \\
\hline 399-1-16B & $2 / 24 / 1987$ & $\mathrm{~b}$ & & & & & & & \\
\hline $399-1-16 \mathrm{C}$ & $2 / 17 / 1987$ & $\bar{a}$ & & & & & & & \\
\hline $399-1-16 \mathrm{C}$ & $2 / 17 / 1987$ & $\mathrm{~b}$ & & & & & & & \\
\hline $399-1-16 C$ & $2 / 17 / 1987$ & C & & & & & & & \\
\hline 699-42-42B & $5 / 26 / 1993$ & $\mathrm{a}$ & assumed & & & 0.00003 & assumed & & \\
\hline 699-42-42B & $5 / 26 / 1993$ & $\mathrm{~b}$ & & & & & & & \\
\hline 699-42-42B & $6 / 1 / 1993$ & & assumed & & & 0.000023 & assumed & & \\
\hline
\end{tabular}




\begin{tabular}{|c|c|c|c|c|c|c|c|c|c|c|c|}
\hline well name & $\begin{array}{c}\text { test start } \\
\text { date }\end{array}$ & sequence & $\begin{array}{c}\text { number of } \\
\text { observation } \\
\text { wells }\end{array}$ & \begin{tabular}{|c|} 
\\
observatio \\
$\mathrm{n}$ well \#3 \\
well name \\
\end{tabular} & $\begin{array}{c} \\
\text { distance } \\
\text { from stress } \\
\text { well [m] } \\
\end{array}$ & $\begin{array}{c}\text { reference } \\
\text { point } \\
\text { elevation } \\
\text { [m] } \\
\end{array}$ & $\begin{array}{c}\text { reference } \\
\text { datum } \\
\text { (ground } \\
\text { surface, } \\
\text { top of } \\
\text { casing, } \\
\text { brass cap. } \\
\text { etc.) }\end{array}$ & \begin{tabular}{|l} 
\\
observation \\
well open \\
interval, top \\
depth below \\
ref point [m]
\end{tabular} & $\begin{array}{c}\text { observation } \\
\text { well open } \\
\text { interval, } \\
\text { bottom } \\
\text { depth below } \\
\text { ref point [m] }\end{array}$ & $\begin{array}{c}\text { percentage } \\
\text { of aquifer } \\
\text { penetration } \\
\text { observation } \\
\text { well (or } \\
\text { unknown) } \\
\end{array}$ & $\begin{array}{c}\text { saturated } \\
\text { open } \\
\text { interval } \\
\text { length [m] }\end{array}$ \\
\hline $399-1-9$ & $3 / 2 / 1987$ & & 3 & \begin{tabular}{|c|}
$399-1-8$ \\
\end{tabular} & 3.7 & & & & & & \\
\hline 399-1-16A & $2 / 26 / 1987$ & $\mathrm{a}$ & 3 & 399-1-16D & 6.40 & & & 32.31 & 35.36 & & 3.05 \\
\hline $399-1-16 \mathrm{~A}$ & $2 / 26 / 1987$ & $\mathrm{~b}$ & 3 & 399-1-16D & 6.40 & & & 32.31 & 35.36 & & 3.05 \\
\hline 399-1-16A & $2 / 26 / 1987$ & C & 3 & 399-1-16D & 6.40 & & & 32.31 & 35.36 & & 3.05 \\
\hline 399-1-16B & $2 / 19 / 1987$ & $\bar{a}$ & 3 & 399-1-16D & 8.56 & & & 32.31 & 35.36 & partial & 3.05 \\
\hline 399-1-16B & $2 / 19 / 1987$ & $\mathrm{~b}$ & 3 & 399-1-16D & 8.56 & & & 32.31 & 35.36 & partial & 3.05 \\
\hline 399-1-16B & $2 / 24 / 1987$ & $\mathrm{a}$ & 3 & 399-1-16D & 8.56 & & & 32.31 & 35.36 & partial & 3.05 \\
\hline 399-1-16B & $2 / 24 / 1987$ & $\mathrm{~b}$ & 3 & 399-1-16D & 8.56 & & & 32.31 & 35.36 & partial & 3.05 \\
\hline $399-1-16 \mathrm{C}$ & $2 / 17 / 1987$ & $\mathrm{a}$ & 3 & 399-1-16D & 5.88 & & & 32.31 & 35.36 & partial & 3.05 \\
\hline $399-1-16 \mathrm{C}$ & $2 / 17 / 1987$ & $b$ & 3 & 399-1-16D & 5.88 & & & 32.31 & 35.36 & partial & 3.05 \\
\hline $399-1-16 \mathrm{C}$ & $2 / 17 / 1987$ & $\mathrm{C}$ & 3 & 399-1-16D & 5.88 & & & 32.31 & 35.36 & partial & 3.05 \\
\hline 699-42-42B & $5 / 26 / 1993$ & $a$ & 3 & $699-43-42$ & 19.51 & & & 49.4 & 54.1 & partial & 4.7 \\
\hline 699-42-42B & $5 / 26 / 1993$ & $\mathrm{~b}$ & 3 & $699-43-42$ & 19.51 & & & 49.4 & 54.1 & partial & 4.7 \\
\hline $699-42-42 B$ & $6 / 1 / 1993$ & & 3 & $699-43-42$ & 19.51 & & & 49.4 & 54.1 & partial & 4.7 \\
\hline
\end{tabular}

Table A.8 Third Observation Well Information and Results 



\section{Distribution}

\section{ONSITE}

6 DOE Richland Operations Office

M. J. Furman A6-38

R. D. Hildebrand A6-38

J. G. Morse A6-38

K. M. Thompson A6-38

DOE Public Reading Room (2) H2-53

4 Bechtel Hanford, Inc.

L. R. Curry H0-09

K. R. Fecht H0-02

G. B. Mitchem H0-19

A. M. Nazarali H9-02

7 CH2M HILL Hanford Group, Inc.

M. P. Connelly E6-35

W. J. McMahon E6-35

M. N. Jarayssi H9-03

C. D. Wittreich E6-35

A. J. Knepp E6-35

F. M. Mann E6-35

D. A. Myers E6-35

1 Fluor Federal Services

R. Khaleel E6-17

6 Fluor Hanford, Inc.

J. V. Borghese E6-35

J. D. Davis E6-35

B. H. Ford E6-35

L. C. Swanson E6-35

D. Wilde E6-35

M. I. Wood H8-44

2 U.S. Environmental Protection Agency

D. R. Einan B5-01

D. A. Faulk B5-01

4 Washington State Department of Ecology

J. Caggiano B5-18

D. Goswami B5-18
J. A. Hedges B5-18

A. D. Huckaby B5-18

47 Pacific Northwest National Laboratory

D. B. Barnett K6-81

M. P. Bergeron K9-36

R. W. Bryce K6-75

J. G. Bush K6-96

A. L. Bunn K6-85

K. J. Cantrell K6-81

C. R. Cole K9-33

J. L. Devary K6-96

R. L. Dirkes K6-75

P. E. Dresel K6-96

J. P. McDonald K6-96

M. J. Fayer K9-33

E. J. Freeman K9-36

M. D. Freshley H0-21

J. S. Fruchter K6-96

G. W. Gee K9-33

T. J Gilmore K6-81

F. N. Hodges K6-81

D. G. Horton K6-81

C. T. Kincaid K9-33

G. V. Last (5) K6-81

T. L. Liikala K6-96

S. P. Luttrell K6-96

C. J. Murray K6-81

S. M. Narbutovskih K6-96

D. R. Newcomer K6-96 (5)

R. G. Riley K6-96

R. M. Smith K6-96

F. A. Spane, Jr. K6-96

P. D. Thorne K9-33 (5)

A. L. Ward K9-33

V. L. Vermeul K6-96

W. D. Webber K6-96

M. D. White K9-36

M. D. Williams K6-36

S. K. Wurstner K9-36

S. B. Yabusaki K9-36

Hanford Technical Library (2) P8-55 